UNIVERSIDADE DE SÃO PAULO

ESCOLA DE ENFERMAGEM DE RIBEIRÃO PRETO

FLÁVIO ADRIANO BORGES MELO

ANÁLISE DE IMPLICAÇÃO PROFISSIONAL: UM DISPOSITIVO DISPARADOR DE PROCESSOS DE EDUCAÇÃO PERMANENTE EM SAÚDE

RIBEIRÃO PRETO 


\title{
ANÁLISE DE IMPLICAÇÃO PROFISSIONAL: UM DISPOSITIVO DISPARADOR DE PROCESSOS DE EDUCAÇÃO PERMANENTE EM SAÚDE
}

\author{
Versão Original \\ Tese apresentada ao Programa de Pós-Graduação em Enfermagem \\ em Saúde Pública da Escola de Enfermagem de Ribeirão Preto da \\ Universidade de São Paulo para obtenção do título de Doutor em \\ Ciências. \\ Área de Concentração: Enfermagem em Saúde Pública. \\ Orientadora: Profa. Dra. Cinira Magali Fortuna.
}

RIBEIRÃO PRETO 
Autorizo a reprodução e divulgação total ou parcial deste trabalho, por qualquer meio convencional ou eletrônico, para fins de estudo e pesquisa, desde que citada a fonte.

\section{Catalogação na Publicação}

Serviço de Biblioteca e Documentação

Escola de Enfermagem de Ribeirão Preto da Universidade de São Paulo

Melo, Flávio Adriano Borges

Análise de implicação profissional: um dispositivo disparador de processos de educação permanente em saúde, 2017.

141 p. : il. ; $30 \mathrm{~cm}$

Tese de Doutorado, apresentada à Escola de Enfermagem de Ribeirão Preto/USP. Área de concentração: Enfermagem em Saúde Pública.

Orientadora: Fortuna, Cinira Magali.

1. Educação Permanente. 2. Política Nacional de Saúde. 3. Enfermagem em Saúde Pública. 4. Saúde Coletiva. 5. Análise Institucional. 
Nome: MELO, Flávio Adriano Borges

Título: Análise de Implicação Profissional: um dispositivo disparador de processos de Educação Permanente em Saúde

Tese apresentada ao Programa de Pós-Graduação em Enfermagem em Saúde Pública da Escola de Enfermagem de Ribeirão Preto da Universidade de São Paulo para obtenção do título de Doutor em Ciências.

Aprovado em:

\section{Banca Examinadora}

$\operatorname{Prof}(a) . \operatorname{Dr}(a)$.

Instituição:

Julgamento:

Prof(a). Dr(a).

Instituição:

Julgamento:

Prof(a). Dr(a).

Instituição:

Julgamento: 
À minha mãe, Jussara Tito Borges, pela vida, incentivo e exemplo de força e persistência. 


\section{AGRADECIMENTOS}

Agradeço à Universidade de São Paulo e ao Programa de Pós-Graduação em Enfermagem em Saúde Pública pela oportunidade de ter cursado meu doutorado nessa organização de ensino superior de referência internacional.

À CAPES pelo auxílio concedido por meio das bolsas de estudo, tanto regular (PROEX) quanto de estágio sanduíche na França (Processo nº 99999.006509/2015-00).

Aos componentes do Núcleo de Pesquisa e Estudos em Saúde Coletiva e ao Grupo de Estudos e Pesquisa em Análise Institucional da Escola de Enfermagem de Ribeirão Preto pelos aprendizados proporcionados e grandes amigos que aqui fiz. Obrigado!

Aos membros do Recherche Avec pela oportunidade dos bons encontros proporcionados a mim e por compor, com vocês, as parcerias em prol da construção de produções científicas inovadoras. Merci beaucoup!

À Profa. Dra. Cinira Magali Fortuna pelo acompanhamento, parceria, aprendizados, amizade... edificados durante toda essa trajetória de doutoramento. Obrigado por tudo!

Ao Prof. Dr. Gilles Monceau por aceitar me receber na França e por me possibilitar um aprendizado ímpar do referencial teórico-metodológico da Socioclínica Institucional, além de aceitar fazer parte da banca de avaliação desta produção. Merci beaucoup!

À Profa. Dra. Solange L'Abbate - por intermédio da qual cumprimento também todos os componentes do grupo AI_L'ABBATE - pela oportunidade de poder cursar a disciplina ministrada na Pós-Graduação da Faculdade de Ciências Médicas da Universidade Estadual de Campinas no ano de 2016, por sua generosidade em compartilhar seus conhecimentos conosco e pelo aceite em compor a banca de avaliação desta tese. Gratidão!

À Profa. Dra. Patrícia Alonso pela receptividade durante o período em que estive na França e pelo aceite em compor minha banca de defesa. Merci beaucoup!

Ao CDQ-III, na pessoa de sua coordenação, Mônica Vilchez, pelo apoio e parceria despendida durante toda essa trajetória. Sou imensamente grato por tudo, minha amiga!

Ao grupo de pesquisadores do PPSUS e InovaSUS pela parceria, aprendizados e auxílio na condução desta pesquisa-intervenção. Sem vocês, seria impossível ter alcançado os resultados e análises desta obra. Muito obrigado a todos e todas!

Aos apoiadores de humanização e articuladores de Educação Permanente em Saúde pela receptividade e disponibilidade para o encontro. Esta obra também é dedicada a cada um de vocês. 
À Prefeitura Municipal de São Carlos pelo apoio e parceria durante a trajetória final de produção desta obra. Obrigado equipe da Unidade de Saúde da Família José Fernando Petrilli Filho.

À gangue moncelle pela amizade, compartilhamentos e aprendizados que me possibilitaram estar aqui, finalizando esta produção. Je vous embrace très fort, mes amis françaises. Merci!

À toda minha família, pelo suporte afetivo e apoio no percurso dessa jornada. Mãe, sogra, irmãs, cunhados, primos, tios, avó, sobrinha... sou imensamente grato a cada um de vocês. Obrigado por existirem e compartilharem comigo de mais essa conquista tão esperada e desejada por mim.

Aos amigos, que aqui não listarei com receio de acabar me esquecendo de algum pelo avançar do tempo e pela necessidade de finalizar essa obra, mas que sabem o quanto são importantes e parte dessa construção. Obrigado por tudo!

E por acreditar na transformação que amor é capaz, agradeço ao meu companheiro de vida, Alexandre Nishiwaki, que percorreu toda essa trajetória ao meu lado, compartilhando comigo das conquistas e angústias que esse percurso gerou em mim e em nossas vidas. Obrigado imensamente pela compreensão, auxílio, diálogo, dedicação, amor e por me fazer acreditar, todos os dias, que somos sempre capazes. Este projeto de vida foi construído e alcançado por nós. Ele é nosso! 
Eu não sou você

Você não é eu

Mas sei muito de mim

Vivendo com você

$E$ você, sabe muito de você vivendo comigo?

Eu não sou você

Você não é eu

Mas encontrei comigo e me vi

Enquanto olhava pra você

Na sua, minha, insegurança

Na sua, minha, desconfiança

Na sua, minha, competição

Na sua, minha, birra infantil

Na sua, minha, omissão

Na sua, minha, firmeza

Na sua, minha, impaciência

Na sua, minha, prepotência

Na sua, minha, fragilidade doce

Na sua, minha, mudez aterrorizada

E você se encontrou e se viu, enquanto olhava pra mim?

Eu não sou você

Você não é eu

Mas foi vivendo minha solidão

que conversei com você

E você conversou comigo na sua solidão

ou fugiu dela, de mim e de você?

Eu não sou você

Você não é eu

Mas sou mais eu, quando consigo

lhe ver, porque você me reflete

No que eu ainda sou

No que já sou e

No que quero vir a ser...

Eu não sou você

Você não é eu

Mas somos um grupo, enquanto

somos capazes de, diferenciadamente, eu ser eu, vivendo com você e

Você ser você, vivendo comigo.

(MADALENA FREIRE, 1993, p. 59-60) 


\section{RESUMO}

MELO, F. A. B. Análise de implicação profissional: um dispositivo disparador de processos de Educação Permanente em Saúde. 2017. 141p. Tese (Doutorado em Ciências da Saúde) - Escola de Enfermagem de Ribeirão Preto da Universidade de São Paulo, Ribeirão Preto, 2017.

Esta tese teve por objetivo geral analisar a implicação profissional com os apoiadores de humanização e os articuladores de Educação Permanente em Saúde (EPS) dos municípios do Departamento Regional de Saúde (DRS) de Araraquara/São Paulo. Trata-se de uma pesquisaintervenção Socioclínica, de abordagem qualitativa, realizada com os apoiadores de humanização e os articuladores de EPS dos 24 municípios que compõem o DRS em questão. Foram realizadas entrevistas individuais com 07 sujeitos que desenvolviam ambas as funções em seus municípios e 12 entrevistas grupais, sendo 11 compostas pelo apoiador e articulador e 01 composta por um grupo de 06 apoiadores do município. Portanto, 35 apoiadores e articuladores participaram da pesquisa-intervenção em questão. Foram também utilizados enquanto dispositivos analíticos para a produção dos dados desta pesquisa-intervenção: dez encontros mensais com os apoiadores e articuladores; sete encontros de planejamento e análise e o diário de pesquisa. As entrevistas e os encontros com os apoiadores e articuladores foram transcritos e as apreensões feitas nos encontros de planejamento e análise foram redigidos no diário de pesquisa. Todo esse material, bem como outras anotações feitas em diário, foi analisado a partir dos princípios da Socioclínica Institucional, sendo que um deles corresponde aos momentos de restituição, possibilitando um aprofundamento coletivo das análises realizadas. Os resultados foram apresentados a partir das dimensões libidinal, ideológica e organizacional que compõem a implicação profissional. Dessa forma, identificamos e analisamos com os apoiadores e articuladores os atravessamentos que a profissão inicial (enfermeiro, dentista, psicólogo, etc.) exerce sobre o fazer apoio; a contradição em se pensar em um perfil pronto para o desenvolvimento dessa função; os sentimentos de desânimo, pessimismo e otimismo enquanto componentes da dimensão ideológica que também atravessam o fazer apoio e a articulação de EPS; o tempo, o modo de fazer a gestão e o poder político enquanto analisadores da dimensão organizacional dos apoiadores e dos articuladores; e a ausência/presença do desejo, a vontade de agradar os profissionais de saúde, desenvolvendo uma relação harmônica no trabalho enquanto pistas analisáveis da dimensão libidinal dos apoiadores e dos articuladores. Na medida que o trabalho de análise com os apoiadores e articuladores prosseguiu, mudanças nos modos de se pensar e fazer apoio às equipes de saúde 
e também o pensar sobre o trabalho de apoiar e articular a EPS foi se modificando, fazendo com que esses profissionais entrassem, eles mesmos, em processos de EPS, refletindo e interrogando o próprio trabalho. O pesquisador ao realizar a análise de implicação também se colocou em processo de interrogação de sua prática, experienciando também a EPS em ato. Concluímos que a análise de implicação profissional consiste em um potente dispositivo disparador de processos de EPS.

Palavras-chave: Educação Permanente. Política Nacional de Saúde. Enfermagem em Saúde Pública. Saúde Coletiva. Análise Institucional. 


\begin{abstract}
MELO, F. A. B. Analysis of professional implication: a device triggering process of Permanent Education in Health. 2017. 141p. Thesis (PhD in Health Sciences) - Nursing School of Ribeirão Preto of the University of São Paulo, Ribeirão Preto, 2017.
\end{abstract}

This thesis had as general objective to analyze the professional implication with the humanization supporters and the articulators of Permanent Health Education (PHE) of the municipalities of the Regional Department of Health (RDH) of Araraquara/São Paulo. It is a Socioclinic intervention research, with a qualitative approach, carried out with the humanization supporters and the articulators of PHE of the 24 municipalities that compose the mentioned RDH. Individual interviews were carried out with 07 participants who performed both functions in their municipalities and 12 group interviews, of which 11 were composed of the supporter and articulator and 01 were composed of a group of 06 supporters of the municipality. Therefore, 35 supporters and articulators participated in the intervention research in question. They were also used as analytical devices for the production of the data of this intervention research: ten monthly meetings with the supporters and articulators; seven planning and analysis meetings and the research diary. The interviews and meetings with the supporters and articulators were transcribed and the apprehensions made in the planning and analysis meetings were written in the research diary. All this material, as well as other diary entries, were analyzed based on the principles of Socioclinic Institutional, one of which corresponds to the moments of restitution, allowing a collective deepening of the analyzes carried out. The results were presented from the libidinal, ideological and organizational dimensions that make up the professional implication. In this way, we identify and analyze with the supporters and articulators the crossings that the initial profession (nurse, dentist, psychologist, etc.) exercises on making support; the contradiction in thinking of a ready profile for the development of this function; the feelings of discouragement, pessimism and optimism as components of the ideological dimension that also cross the support and articulation of PHE; time, management and political power as analysts of the organizational dimension of supporters and articulators; and the absence/presence of desire, the willingness to please health professionals, developing a harmonious relationship at work as analysable clues to the libidinal dimension of supporters and articulators. As the work of analysis with the supporters and articulators continued, changes in ways of thinking and supporting health teams and also thinking about the work of supporting and articulating the PHE was changing, causing these professionals to enter, themselves, in processes of PHE, reflecting and questioning the work 
itself. The researcher, when performing the implication analysis, also put himself in the process of interrogating his practice, also experiencing PHE in action. We conclude that the professional implication analysis consists of a powerful device triggering PHE processes.

Keywords: Permanent Education. National Health Policy. Public Health Nursing. Collective Health. Institutional Analysis. 


\section{RESUMÉ}

MELO, F. A. B. Analyse de l'implication professionnelle: un dispositif déclenchement de processus d'éducation permanente en santé. 2017. 141p. Thèse (Doutorat en Sciences de la Santé) - École des Sciences Infirmières de Ribeirão Preto de l'Université de São Paulo, Ribeirão Preto, 2017.

Cette thèse avait pour objectif général d'analyser l'implication professionnelle avec les travailleurs qui font de l'appui en santé et les articulateurs de l'Éducation Permanente en Santé (EPS) des municipalités du Département Régional de Santé (DRS) d'Araraquara/São Paulo. Il s'agit d'une recherche-intervention socioclinique, avec une approche qualitative, réalisée avec les partisans de l'humanisation et les articulateurs d'EPS des 24 municipalités qui composent le DRS en question. Des entretiens individuels ont été effectués avec 07 sujets qui ont exercé ces deux s fonctions dans leurs municipalités et 12 entretiens collectifs. 11 de ces entretiens ont été composés par le travailleur qui fait de l'appui en santé et l'articulateur et 01 par un groupe de 06 travailleurs qui font de l'appui dans la municipalité. Par conséquent, 35 travailleurs qui font de l'appui et de l'articulation ont participé à la recherche-intervention en question. Ils ont également été utilisés comme dispositifs analytiques pour la production des données de cette recherche-intervention: rencontres de dix mois avec les partisans et les articulateurs; sept réunions de planification et d'analyse et le journal de recherche. Les entretiens et les rencontres avec les travailleurs qui font l'appui et les articulateurs ont été transcrites et les appréhensions faites dans les réunions de planification et d'analyse ont été décrites dans le journal de recherche. Tout ce matériel, ainsi que d'autres publications, ont été analysés sur la base des principes de la Socioclinique Institutionel, dont l'un correspond aux moments de restitution, permettant un approfondissement collectif des analyses réalisées. Les résultats ont été présentés à partir des dimensions libidinales, idéologiques et organisationnelles qui constituent l'implication professionnelle. De cette façon, nous identifions et analysons avec les sujets les croisements que la profession initiale (infirmière, dentiste, psychologue, etc.) exerce sur le soutien; la contradiction à penser à un profil prêt pour le développement de cette fonction; les sentiments de découragement, de pessimisme et d'optimisme en tant que composantes de la dimension idéologique qui traversent également le soutien et l'articulation du EPS; le temps, la gestion et le pouvoir politique en tant qu'analyste de la dimension organisationnelle des sujets; l'absence/présence du désir, la volonté de faire plaisir aux professionnels de la santé, en développant une relation harmonieuse au travail comme indices analysables de la dimension libidinale des travailleurs qui font de l'appui et des articulateurs. Au fur et à mesure que le 
travail d'analyse avec les sujets a continué, les changements dans les modes de réflexion et d'appui aux équipes de santé et la réflexion sur le travail de soutien et d'articulation de l'EPS évoluaient, ce qui a amené ces professionnels à entrer, eux-mêmes, dans les processus d'EPS, reflétant et interrogeant le travail lui-même. Le chercheur, lors de l'analyse de l'implication, s'est également mis en train d'interroger sa pratique, ayant également un EPS en action. Nous concluons que l'analyse d'implication professionnelle consiste en un dispositif puissant déclenchant des processus d'EPS.

Mots clés : Éducation Permanente. Politique Nationale de Santé. Infirmiers en Santé Publique. Santé Collective. Analyse Institutionnelle. 


\section{LISTA DE TABELAS}

Referências dos artigos excluídos da revisão integrativa com os

Tabela 1 - respectivos motivos de exclusão

Tabela 2 - Referências dos artigos selecionados para análise na revisão integrativa 54

Tabela 3 - Disposição dos entrevistados a partir de suas formações profissionais 


\section{LISTA DE ABREVIATURAS E SIGLAS}

\begin{tabular}{|c|c|}
\hline $\mathrm{ABP}$ & Aprendizagem Baseada em Problemas \\
\hline APS & Atenção Primária à Saúde \\
\hline BDENF & Base de Dados de Enfermagem \\
\hline CAAE & Certificado de Apresentação para Apreciação Ética \\
\hline CIR & Comissão Intergestores Regional \\
\hline CNS & Conferência Nacional de Saúde \\
\hline CNRHS & Conferências Nacionais de Recursos Humanos para a Saúde \\
\hline CTH & Câmara Técnica de Humanização \\
\hline CDQ-SUS & Centro de Desenvolvimento e Qualificação para o SUS \\
\hline CDQ-III & $\begin{array}{l}\text { Centro de Desenvolvimento e Qualificação para o SUS de } \\
\text { Araraquara }\end{array}$ \\
\hline $\mathrm{DCN}$ & Diretrizes Curriculares Nacionais \\
\hline DEnf & Departamento de Enfermagem \\
\hline DRS & Departamento Regional de Saúde \\
\hline EERP/USP & $\begin{array}{l}\text { Escola de Enfermagem de Ribeirão Preto/Universidade de São } \\
\text { Paulo }\end{array}$ \\
\hline EC & Educação Continuada \\
\hline EP & Educação Permanente \\
\hline EPS & Educação Permanente em Saúde \\
\hline ESF & Estratégia Saúde da Família \\
\hline GTH & Grupos de Trabalho de Humanização \\
\hline IDH & Índice de Desenvolvimento Humano \\
\hline IEP/SL & Instituto de Ensino e Pesquisa do Hospital Sírio Libanês \\
\hline LILACS & Literatura Latino-Americana e do Caribe em Ciências de Saúde \\
\hline MEDLINE & Medical Literature Analyses and Retrieval System \\
\hline MS & Ministério da Saúde \\
\hline NASF & Núcleo de Apoio à Saúde da Família \\
\hline OMS & Organização Mundial da Saúde \\
\hline OPAS & Organização Pan-Americana da Saúde \\
\hline PBL & Problem Based Learning \\
\hline PEH & Política Estadual de Humanização \\
\hline PET-Saúde & Programa de Educação pelo Trabalho para a Saúde \\
\hline PFST & Programa de Formação em Saúde do Trabalhador \\
\hline PNEPS & Política Nacional de Educação Permanente em Saúde \\
\hline PNH & Política Nacional de Humanização \\
\hline PNHAH & Programa Nacional de Humanização na Atenção Hospitalar \\
\hline PPGESP & $\begin{array}{l}\text { Programa de Pós-Graduação em Enfermagem em Saúde } \\
\text { Pública }\end{array}$ \\
\hline PPSUS & Pesquisa para o SUS \\
\hline Pró-Saúde & $\begin{array}{l}\text { Programa Nacional de Reorientação da Formação Profissional } \\
\text { em Saúde }\end{array}$ \\
\hline PT & Partido dos Trabalhadores \\
\hline PTS & Projeto Terapêutico Singular \\
\hline RRAS 13 & Rede Regional de Atenção à Saúde 13 \\
\hline SUDS & Sistema Único Descentralizado de Saúde \\
\hline SUS & Sistema Único de Saúde \\
\hline UFSCar & Universidade Federal de São Carlos \\
\hline UFSM & Universidade Federal de Santa Maria \\
\hline
\end{tabular}


UFTM

UNESCO

UNICAMP

USF
Universidade Federal do Triângulo Mineiro

Organização das Nações Unidas para a Educação, a Ciência e a Cultura

Universidade Estadual de Campinas

Unidade de Saúde da Família 


\section{LISTA DE ANEXOS}

Anexo 1 - Certificado de Apresentação e Apreciação Ética 


\section{LISTA DE APÊNDICES}

Distribuição dos Apoiadores de Humanização segundo os respectivos Apêndice 1 - municípios que compõem o DRS de Araraquara

Distribuição dos Articuladores de Educação Permanente em Saúde segundo os Apêndice 2 - respectivos municípios que compõem o DRS de Araraquara

Apêndice 3 - Termo de Consentimento Livre e Esclarecido 


\section{SUMÁRIO}

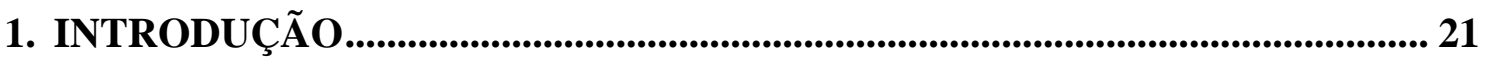

1.1. Notas preliminares: algumas implicações do autor .......................................... 21

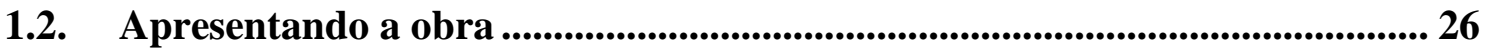

2. REFERENCIAL TEÓRICO E METODOLÓGICO ............................................. 29

3. O PROCESSO DE FORMAÇÃO EM SAÚDE NO BRASIL: ALGUNS

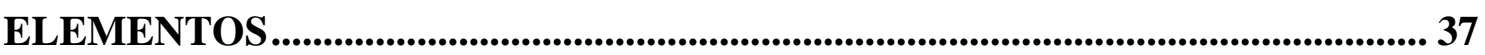

4. A EDUCAÇÃo PERMANENTE EM SAÚde ENQUANTO POLÍTICA DE FORMAÇÃO DE PROFISSIONAIS PARA O SUS .................................................. 47

5. AS POLÍticas NACIONAL E ESTADUAL DE HUMANIZAÇÃO E O APOIO

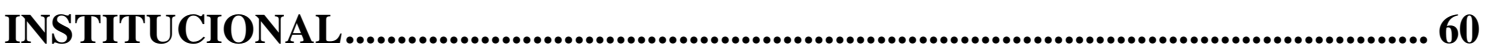

6. DELINEAMENTO DO PROBLEMA DE PESQUISA E JUSTIFICATIVA.... 69

7. OBJETIVOS GERAL E ESPECÍFICOS ......................................................... 73

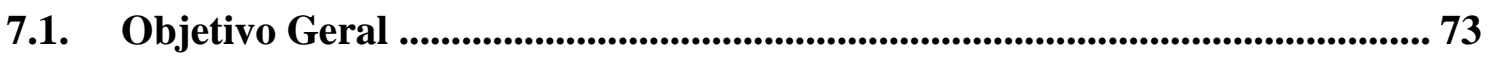

7.2. Objetivos Específicos................................................................................... 73

8. PERCURSO METODOLÓGICO................................................................................ 74

8.1. Tipo de Estudo .................................................................................................... 74

8.2. Caracterização do Local do Estudo ............................................................... 75

8.3. Participantes do estudo .............................................................................. 77

8.4. Aspectos éticos da pesquisa-intervenção ................................................... 78

8.5. Dispositivos analíticos utilizados na produção dos dados............................... 79

8.5.1. Entrevista individual e grupal ......................................................................... 80

8.5.2. Encontros com os apoiadores e articuladores ............................................ 82

8.5.3. Encontros de planejamento e análise ............................................................. 84

8.5.4. Diário de pesquisa .............................................................................. 85

8.6. Análise dos Dados .................................................................................................... 86

9. ANÁLISE DE ALGUMAS IMPLICAÇÕES DO PESQUISADOR .................... 88

10. A ANÁliSE DE IMPLICAÇÃO PROFISSIONAL: A ORQUESTRA DOS APOIADORES DE HUMANIZAÇÃO E ARTICULADORES DE EPS............... 100

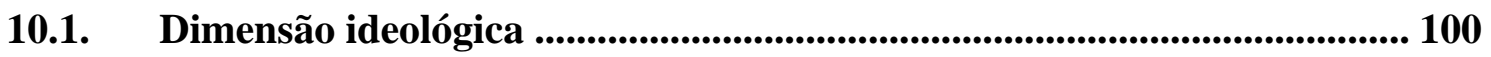

10.2. Dimensão organizacional ................................................................ 110

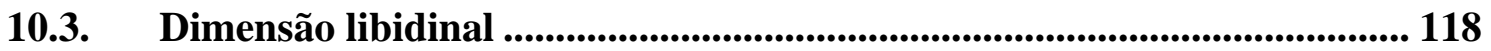

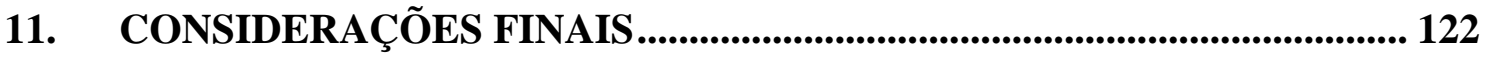


REFERÊECIAS _..................................................................................................... 125

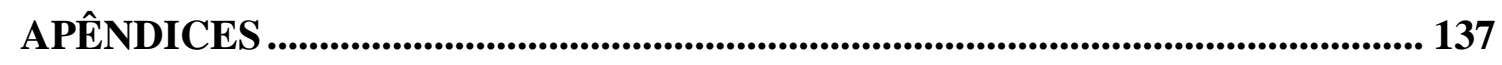

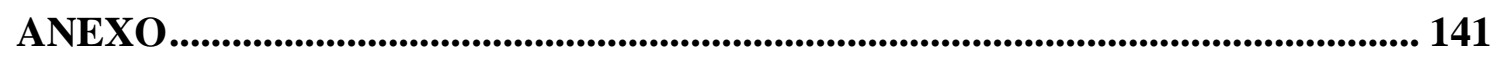




\section{INTRODUÇÃO}

O texto vai ser lido por outras pessoas, primeiro as mais próximas, de quem se espera uma opinião, uma crítica, e até (por que não?) um elogio. E, provavelmente, sugestões para melhorar o texto. Depois, espero que ele seja lido por um público mais amplo, melhor ainda se for de outra área. E, daí, o trabalho vai 'cair no mundo' e vou perder todo e qualquer controle sobre ele. Ou seja, escrever é uma grande aventura, que uma vez iniciada... deve-se ir até o fim (L'ABBATE, 2013, p. 31).

\subsection{Notas preliminares: algumas implicações do autor}

Ser Mineiro é dizer "uai", é ser diferente, é ter marca registrada, é ter história.

Ser Mineiro é ter simplicidade e pureza, humildade e modéstia, coragem e bravura, fidalguia e elegância.

(Carlos Drummond de Andrade)

Nascido em Cássia, uma pequena cidade do interior de Minas Gerais, filho de uma pedagoga e um caminhoneiro e irmão de duas mulheres. Sempre bastante ligado a minha mãe, identificando nela uma grande profissional e também por sempre admirá-la enquanto mulher, mãe de três filhos, educadora e do lar. Cresci em um ambiente com pouca presença paterna e esta, quando existente, acontecia como em um "corte lacaniano", ou seja, de maneira contundente, pontual e precisa. Muitas vezes carregada de força, temperamento hostil e pouca sensibilidade.

Diante desse contexto, mais feminino que masculino, e da representação de feminilidade e de masculinidade percebida em casa, fui me formando enquanto sujeito. Sujeito-criança, sujeito-irmão, sujeito-primo, sujeito-família. Ainda nessa época, agreguei a sensibilidade da música a essa formação pessoal. Cresci intelectualmente e humanamente por fazer parte, por mais de 08 anos, do conservatório de meninos cantores, regido por um grande ícone regional repleto de inteligência, formação e humildade (Prof. Heitor Combat). Foi aí que edifiquei minhas únicas amizades masculinas cassienses, formadas pela transformação do que seria masculinidade para mim, onde a sensibilidade, parceria e diálogo também podiam se fazer presentes.

Já era homossexual, apesar do constante processo de negação bastante comum àqueles que se descobrem homossexuais. Medo da figura paterna, receio da opinião dos amigos mais próximos, da família e do julgamento da sociedade da cidade pequena. Sempre recorri ao apoio 
de figuras femininas que muito me acolheram e me ajudaram nesse processo, por vezes, bastante difícil e doloroso.

Foi nesse contexto e por meio da educação em casa, nas escolas e no conservatório de música que edifiquei minha base de princípios e ensino para ingressar na Universidade Pública. Buscar compreender o outro, lidar com situações precisas, meticulosas, subjetivas e a existência de uma sensibilidade que fosse transversal às funções profissionais eram algumas características que me atraíam bastante à escolha de uma profissão (e também foram apontadas por um padrinho como sendo alguns dos meus potenciais) e que me fizeram optar pela Enfermagem.

Lembro-me de suas palavras [padrinho] até hoje: 'você tem que procurar por alguma profissão que lide com coisas precisas, minuciosas, como farmácia, biomedicina... você consegue lidar com coisas que necessitam de uma precisão, de delicadeza... Enfermagem! Já pensou em fazer Enfermagem?' (diário de pesquisa, 21/07/2013).

Em 2005 iniciei a composição de uma música intitulada "Bacharelado em Enfermagem" pela Universidade Federal do Triângulo Mineiro - UFTM, onde pude ter contato com as disciplinas e conteúdos necessários para a formação de um enfermeiro generalista. Foi minha primeira tentativa de compor uma música e não é que deu certo! E como todo compositor, existem predileções. Alguns preferem acordes dissonantes, outros mais harmônicos. Eu sempre tive fascínio pela Atenção Primária à Saúde (APS), realizando grande parte das atividades extracurriculares em cursos de extensão na comunidade e em estágios rurais. Em 2009, finalizei essa produção mais teórica que prática e tive minha primeira oportunidade de emprego em um "conservatório", ou melhor, hospital situado na região do Pontal do Triângulo Mineiro. Já, naquela época, questionava sobre como os "músicos que compunham as orquestras", ou seja, os profissionais de enfermagem, sobretudo, os técnicos e auxiliares, conseguiam lidar com o cotidiano do trabalho dentro de um "conservatório"/hospital (e, em sua maioria, mais de um “conservatório"/hospital). O que/quem os apoiava?

Movido pelo encanto com os acordes da Estratégia Saúde da Família (ESF), com os da Saúde Coletiva e pela busca incessante de respostas as minhas indagações e inquietudes de um recém-profissional de saúde, ingressei na Residência Multiprofissional em Saúde da Família e Comunidade pela Universidade Federal de São Carlos (UFSCar). Esta foi minha despedida de Minas Gerais - lugar onde pensei que voltaria a trabalhar, mas ainda não voltei - exceto em momentos estratégicos como quando da necessidade de uma inspiração maior, de retomar o contato com minha "essência mineira" para a produção desta obra: 
Tive que retornar a Minas Gerais. Retornei em busca da paz e tranquilidade que essa terra me proporciona. Um conforto ao coração estar perto da família e, ao mesmo tempo, ouvindo os sons mineiros que induzem à criatividade, à produção, à reflexão. Quando volto para cá, sinto a leveza e a simplicidade da vida. Encontro minha avó, mãe, irmãs, tios, primos que ficam todos com aquele ponto de interrogação enorme no rosto e querendo dizer: "Mas o que você faz aqui, durante a semana?". Quando explico de toda essa necessidade eles "fingem" compreender, mas sinto que gostam muito da minha presença (como se não precisassem de explicações e que apenas minha presença já era o suficiente). A matriarca da família, em sua sinceridade descomedida, logo diz: "Até quando você vai estudar, meu filho? Tenho medo de você ficar doido de tanto ler". Só digo: "Fique tranquila, vó. A trajetória que eu escolhi exige estudo para o resto da vida. E louco, todos nós somos um pouco, né?". Ela balança a cabeça pensativa: "É. Você tem razão". Risos, café e pão de queijo. Tem coisa melhor que isso não (diário de pesquisa, 10/04/2017).

Na residência, tive a oportunidade de compor mais uma obra. Dessa vez, mais prática que teórica. Pude vivenciar intensamente os serviços de saúde públicos, as ESF, a articulação da rede de saúde do município de São Carlos e me encantar, de fato, com a complexidade do trabalho realizado nesse ambiente de produção de melodias. Ainda alí, vivenciei a potencialidade do apoio, junto dos meus amigos, também residentes, que representavam o Núcleo de Apoio à Saúde da Família (NASF). A partir de então, a sensação era de que "o céu era o limite". Novas orquestras e experiências se faziam necessárias e novas obras e trajetos deveriam ser compostos e percorridos por mim.

Como quem veio de uma cidade pequena do interior de Minas Gerais e descobre as belezas e maravilhas de uma cidade grande, eu me deslumbro com o apoio. Seja ele matricial (vivido por mim enquanto membro de uma equipe de referência da ESF de uma unidade desse município) seja o institucional (desenvolvido por mim e meus pares enquanto residentes e profissionais que se encontravam no "entre"). Entre o serviço e a Universidade, entre a equipe e os usuários, entre a prática profissional e a pesquisa, entre o compositor e a música.

Sempre tocado por aquilo que parece belo, "que enche os olhos", desafiador e ansiado por mais uma composição, ingressei-me no Mestrado Profissional em Gestão da Clínica, pela mesma Universidade, enquanto cursava meu segundo ano de residência. Compus a obra intitulada "Gerenciamento do trabalho em saúde: as concepções de profissionais e usuários da Estratégia Saúde da Família" ${ }^{1}$, estando totalmente sobreimplicado ${ }^{2}$, pois investiguei o gerenciamento do trabalho da Unidade de Saúde da Família (USF) em que permaneci durante

\footnotetext{
${ }^{1}$ Pesquisa que gerou o artigo intitulado "Gerenciamento em saúde: o olhar de trabalhadores da saúde da família rural” publicado na Revista Ciência, Cuidado e Saúde, 15(2): 466-473, 2016.

${ }^{2}$ Termo concernente ao referencial teórico e metodológico da Análise Institucional e que será melhor explicitado no $2^{\circ}$ ato desta obra.
} 
a maior parte da minha residência, sem analisar o fato de que eu era um dos profissionais que compunha aquela equipe e que interferia, diretamente, no gerenciamento do trabalho local, ou seja, possuía as minhas implicações ${ }^{3}$ com o gerenciamento do trabalho em saúde daquela USF, com aquela equipe, com o cuidado aos usuários daquela realidade, etc. Como um músico, que quer escutar sua composição, mas não leva em consideração o som do seu instrumento e o efeito que ele desenvolve no conjunto da orquestra.

A sobreimplicação foi extrema e hoje compreendo que algumas demandas não foram atendidas por aquela composição. Contudo, por encarar a formação profissional enquanto um processo onde o homem é um ser inconcluso, consciente da minha inconclusão e do permanente movimento de busca em ser mais (FREIRE, 2008), identifico que foi o possível de ser desenvolvido naquele momento. Inclusive, talvez o fato de não poder dizer de algumas coisas naquele momento me fez aproximar do referencial teórico e metodológico que me proponho a utilizar aqui, nessa composição.

Admito ter sido por intermédio dos estudos que encontrei meu refúgio. Caminho encontrado e trilhado por mim para também obter o respeito e admiração dos familiares e dos cassienses, afinal, sendo homossexual, de uma cidade pequena do interior de Minas Gerais, sentia que necessitava "compensar" isso de alguma outra forma. Como um músico que está com seu instrumento desafinado e que não pode parar de tocar, mas que se articula soprando mais fraco ou mais forte para tentar manter a afinação da orquestra. Essa era a minha (e de muitos amigos homossexuais) sensação: "ter nascido desafinado".

Para além do jeito mineiro de ser, acredito também ter sido por meio da música que obtive essa tranquilidade (aparente) e sensibilidade, sobretudo, do olhar e a disciplina, necessários a todo pesquisador.

Ainda em processo de finalização do mestrado, trabalhei enquanto funcionário público em um pequeno município do interior de São Paulo. Minha saída desse município se deu logo após a chegada do meu título de mestre. Coincidência para mim, naquela época. Deixei esse concurso com a "desculpa" de ter sido aprovado em um novo programa de Residência, mas dessa vez, em Saúde Mental, pela Universidade Estadual de Campinas (Unicamp). Foi alí que percebi que meus descontentamentos, enquanto funcionário público, advinham da escassez de espaços garantidos de formação e reflexão da prática profissional pelos/para os trabalhadores de saúde, além de identificar minha grande afinidade por esses momentos e por considerá-los

\footnotetext{
${ }^{3}$ Ídem nota de rodapé $n^{\mathbf{o}} 2$.
} 
de extrema relevância para um bom desenvolvimento do trabalho em saúde (reuniões de equipe, acompanhamento clínico e institucional, tutoria com os residentes, etc.).

Há quem diga que minha estadia na Unicamp durou apenas um mês. Para mim, durou o suficiente para que eu pudesse ter a clareza e necessidade de alçar novos desafios profissionais. Estes vieram uma semana após retornar a São Carlos, por meio de um convite para compor a equipe de assessores dos projetos do Programa Nacional de Reorientação da Formação Profissional em Saúde (Pró-Saúde) e do Programa de Educação pelo Trabalho para a Saúde (PET-Saúde), pelo Ministério da Saúde. Em seguida, fui também convidado a ser facilitador dos cursos de aprimoramento do Instituto de Ensino e Pesquisa do Hospital Sírio Libanês (IEP/SL) e assim continuei o exercício da função apoio, neste momento, articulado ao ensino.

Ensino que aprendi nas escolas, no conservatório de música, em casa, na faculdade, no contato com os usuários, com professores, mestres, amigos... Apoio enquanto algo fundamental para disparar processos analíticos em nossos cotidianos. E assim, ingresso-me no doutorado, propondo a confecção de mais uma obra, ainda pouco delineada no momento de ingresso, mas que se debruçava sobre as temáticas da formação e do apoio institucional em saúde.

Enquanto doutorando, imergi no campo de intervenção ${ }^{4}$ por meio de outros projetos de pesquisa, articulei novas parcerias, cursei disciplinas relevantes ao processo de formação no ensino e na pesquisa, realizei atividades práticas de docência, ingressei em grupos de estudos e na Rede Internacional Recherche Avec composta por franceses, canadenses, brasileiros e mexicanos e que me possibilitou muitos momentos de reflexão, bons encontros e grandes oportunidades como a de realizar o aprofundamento teórico e metodológico no referencial da socioclínica (referencial utilizado nessa produção) por meio de um estágio sanduíche de dez meses na França 5 .

Esse processo de delineamento do objeto de estudo se faz como em uma composição musical. Há a necessidade de debruçar-se sobre a obra, tocá-la diversas vezes, aprimorá-la, discuti-la com amigos, parceiros, mestres e sentir, em algum momento, que aquela obra já não é mais só sua, mas que reflete uma parte de um longo processo da sua vida. O objeto desse estudo foi sendo tratado, delimitado pouco a pouco e, ao parar para refletir, percebo que ele não é mais só meu, mas fruto de uma trajetória enquanto doutorando e de um contínuo debruçar-se sobre ele. Tenho comigo que fui escolhendo e sendo escolhido pelo objeto e isso aconteceu naturalmente, como em um romance.

\footnotetext{
${ }^{4}$ Campo de intervenção corresponde a todo espaço e tempo disponibilizados para que o interventor realize a intervenção (LOURAU, 1997).

${ }^{5}$ Estágio sanduíche com bolsa de estudos financiada pela CAPES Processo no 99999.006509/2015-00.
} 
Nesse romance, cantei várias músicas solo, a capela, com acompanhamento, em conjunto, harmônicas e desarmônicas. Ainda em processo permanente de formação, cantando, desafinando e diante desse contexto rico, de grandes encontros, afetos e oportunidades, que elaboramos ${ }^{6}$ mais essa obra, que já iniciou a partir da exposição dessas implicações e que serão retomadas, em análise, posteriormente.

\subsection{Apresentando a obra}

Consideramos obra a partir das contribuições feitas por Campos (2007), que a difere em duas dimensões: uma onde os músicos não influenciam diretamente na composição, cabendo ao compositor esse papel e outra que corresponde a execução da sinfonia propriamente dita, que, aí sim, é construída por um coletivo, sob a regência do maestro. Acreditamos que a presente obra tenha sido redigida por mim, mas composta a partir de construções, execuções e regências de um coletivo de sujeitos.

Essa produção procura atender à encomenda ${ }^{7}$ do Programa de Pós-Graduação em Enfermagem em Saúde Pública (PPGESP) como parte dos pré-requisitos para a obtenção do título de doutor em Ciências pela Escola de Enfermagem de Ribeirão Preto/Universidade de São Paulo (EERP/USP). Dessa forma, não há como escaparmos das exigências formais, estruturais e instituídas da confecção de uma tese. O que buscaremos, contudo, é analisarmos as implicações ${ }^{8}$ no ato de escrever, conforme propôs Lourau (2014), e articularmos a ideia dessa obra a uma apresentação de um concerto de gala.

A intenção é que as melodias aqui expostas possam ser, sinestesicamente, agradáveis aos olhos e aí procuramos atender a mais uma encomenda que é a realização de uma produção que possa ser lida e compreendida pelos profissionais de saúde que tiverem contato com ela. Para isso, foram necessários vários ensaios antes de sua estréia. Contudo, os deslizes, os erros nos acordes e no dedilhamento das notas no instrumento são inevitáveis, sobretudo, pelas implicações ${ }^{8}$ do autor com sua obra, com o momento de seu feitio e com o momento de sua estréia.

\footnotetext{
${ }^{6} \mathrm{O}$ tempo verbal no plural se deve ao fato de compreendermos a pesquisa enquanto uma produção coletiva, que se dá a partir do encontro com outros sujeitos, culminando com a configuração desse trabalho que aqui se encontra. Utilizaremos a primeira pessoa do singular ou "autor principal" quando nos referirmos a Flávio Adriano Borges Melo, principal responsável pela escrita dessa obra.

${ }^{7}$ Termo concernente ao referencial teórico e metodológico da Análise Institucional e que será melhor explicitado no $2^{\circ}$ ato desta obra.

8 Ídem nota de rodapé $n^{\circ} 7$.
} 
Assim, fugiremos do script de uma apresentação de tese formal que se encontra organizada por seções, mas obedeceremos à estrutura de um concerto, um pouco mais longo, um pouco diferente, composto por 11 atos.

Nesse sentido, e a partir da exposição já realizada de algumas implicações minhas e que, posteriormente, serão retomadas em análise em conjunto com as demais implicações que se encontram nessa produção, contemplamos no $2^{\circ}$ ato o referencial teórico e metodológico que embasam e fundamentam o escopo dessa obra. Trata-se da Socioclínica Institucional, onde procuramos contextualizá-la enquanto modalidade interventiva da Análise Institucional, apresentando seus princípios, a origem destes e seus significados.

O $3^{\circ}$ ato é composto por um resgate histórico da formação em saúde a partir do surgimento da primeira Universidade no Brasil, perpassando pelos principais movimentos que interferiram na formação universitária em saúde e expondo uma análise crítica sobre a circunstância atual no que tange à temática.

No $4^{\circ}$ ato apresentamos a Educação Permanente em Saúde (EPS) enquanto política que tem por objetivo principal a busca pela emancipação do trabalhador por meio da reflexão da própria prática profissional, além da indução a um processo de formação contextualizada ao Sistema Único de Saúde (SUS), perpassando por sua idealização, criação e as divergências existentes com relação a sua concepção teórico-prática. Aqui, também apresentamos uma revisão integrativa de literatura científica que gira em torno da EPS articulada à Enfermagem.

Em conseguinte, no $5^{\circ}$ ato, abordamos acerca da Política Nacional de Humanização (PNH) enquanto uma política que tem por objetivo a valorização das dimensões subjetiva e social na prática de atenção e de gestão dos serviços de saúde. Fizemos uma contextualização da política e apresentamos seu método, princípios, diretrizes, ferramentas e dispositivos. Para tanto, construímos a ideia de ferramenta para essa obra a partir das contribuições de Gilles Deleuze e Émerson Merhy e também utilizamos de Michel Foucault, Giorgio Agamben e Gilles Monceau para definirmos dispositivo, a partir da concepção trazida pela PNH. Em seguida, adentramos ao dispositivo do apoio institucional e às particularidades apresentadas pelo estado de São Paulo nesse quesito, fazendo um paralelo com a Política Estadual de Humanização $(\mathrm{PEH})$ e os arranjos organizativos desse estado.

No $6^{\circ}$ ato fizemos um delineamento do problema de pesquisa a partir dos atos teóricos apresentados previamente e justificando a relevância dessa produção e suas contribuições para a Saúde Coletiva, Análise Institucional, Saúde Pública e Enfermagem. Esse ato foi seguido pelo $7^{\circ}$, onde apresentamos os objetivos da pesquisa-intervenção que compõe essa obra. 
No $8^{\circ}$ ato colocamos o percurso metodológico percorrido na realização da pesquisaintervenção, trazendo o tipo de estudo realizado, a caracterização do local do estudo, os sujeitos que o compõe, os aspectos éticos utilizados na produção da pesquisa-intervenção em questão, os dispositivos analíticos ${ }^{9}$ colocados em prática na intervenção socioclínica e a forma como se deu a análise dos dados da pesquisa.

No $9^{\circ}$ ato iniciamos a apresentação dos resultados da pesquisa-intervenção, por meio da análise de implicação do pesquisador fazendo, para isso, uma retomada a alguns itens constantes nas notas preliminares dessa obra. Em conseguinte, no $10^{\circ}$ ato apresentamos e discutimos acerca da composição analítica das implicações profissionais dos apoiadores de humanização e articuladores EPS, a partir dos dispositivos analíticos colocados em prática no desenvolvimento da pesquisa-intervenção.

A obra é seguida pelas considerações finais que têm a pretensão de fechar os acordes entoados no transcorrer dessa produção, procurando reafirmar a defesa da tese abaixo proposta.

Esperamos que, com a estreia e apresentação dessa obra, possamos defender a tese de que a análise da implicação profissional consiste em um dispositivo capaz de disparar processos de EPS nos coletivos.

\footnotetext{
${ }^{9}$ Esse termo será melhor explicitado no $5^{\circ}$ ato desta obra a partir das contribuições de Gilles Monceau (2015).
} 


\section{REFERENCIAL TEÓRICO E METODOLÓGICO}

Essa tese se fundamenta teórica e metodologicamente nas ideias do movimento institucionalista que teve seu início na França, na década de 60, e no Brasil em meados dos anos 70 (L’ABBATE, 2003; 2012). Assim como Rodrigues (1994), referimos ao movimento como institucionalista devido à grande diversidade de autores que contribuíram para a formação da Análise Institucional. Desta forma, compreendemos o institucionalismo enquanto algo mais amplo, que visou deflagrar nos coletivos sociais processos de auto-análise e autogestão (BAREMBLITT, 2012).

Dentro do movimento institucionalista, consideramos a existência de algumas correntes $^{10}$ que são a Análise Institucional, a Socioanálise e a Esquizoanálise. A Análise Institucional e a Socioanálise se embasam na dialética (apoiada em Hegel e Castoriadis) e são originadas, sobretudo, das obras de René Lourau e Georges Lapassade, enquanto que a Esquizoanálise é inspirada na filosofia da diferença e está vinculada às obras de Félix Guatarri e Gilles Deleuze (BAREMBLITT, 2012).

Apesar de alguns conceitos comporem tanto uma corrente quanto outra, dificultando o estabelecimento de limites precisos entre elas (L'ABBATE, 2012), temos a pretensão de nos aproximarmos mais da vertente louraudiana e lapassadiana, sobretudo, pelo formato de trabalho que propusemos desenvolver e que está diretamente vinculado aos princípios da Análise Institucional e da Socioanálise. Contudo, também utilizaremos alguns conceitos da Esquizoanálise na fundamentação teórica de alguns movimentos e análises, compreendendo que ambas correntes se articulam, apesar das particularidades existentes em cada uma delas.

Tal afirmação vem do fato de que a Análise Institucional tem por objetivo compreender uma realidade social e organizacional a partir das práticas e discursos dos sujeitos, utilizando de um conjunto de conceitos que se articulam e da dialética da instituição (LOURAU, 2014).

Para Lourau (2004), a instituição consiste nas normas e a forma como os sujeitos concordam ou não em fazer parte delas. Esta, por sua vez, se organiza, desorganiza e reorganiza por meio dialético dos três momentos que a compõe: instituído, instituinte e institucionalização.

$\mathrm{O}$ instituído corresponde àquilo que é aparente, visível, identificado da instituição. $\mathrm{O}$ instituinte consiste naquilo que desloca, provoca, movimenta o instituído. E esta dialética do instituído e instituinte corresponde, por sua vez, ao processo de institucionalização (LOURAU,

\footnotetext{
${ }^{10}$ Adotaremos, para fins didáticos, a denominação de correntes do institucionalismo ao nos referirmos à Análise Institucional, Socioanálise e Esquizoanálise apesar de existirem outras denominações comumente utilizadas na literatura (L'ABBATE, 2013).
} 
2014). É dialético por seguir a mesma lógica hegeliana onde uma forma nega a outra e é um processo por se tratar de algo inacabado, sempre em movimento, infindado.

A relação dialética e contrária entre o instituído e o instituinte não tem uma característica maniqueísta entre bem e mal, mas uma concepção que está ligada à dinâmica social que repousam os fundamentos da Análise Institucional. O instituído e o instituinte são duas instâncias ligadas, dependentes e que se alimentam, se ameaçam, se destroem e se reconstroem entre si mesmos (BELLEGARDE, 2002).

Baseado nesses conceitos, René Lourau adotou uma prática clínica de intervenção para colocar em ato a Análise Institucional. Tal prática interventiva foi denominada de Socioanálise (ARDOINO; LOURAU, 2003). Ele procurou, a partir de intervenções realizadas com Georges Lapassade em escolas, associações, sindicatos, setores da igreja e universidades, desenvolver as condições teóricas e práticas para o desenvolvimento dessa corrente, elaborando conceitos considerados como princípios da Socioanálise (L’ABBATE, 2012).

As intervenções socioanalíticas são, em sua essência, de curta duração e têm o objetivo de desvelar rapidamente aquilo que estava oculto da instituição. Com o passar do tempo, as modalidades de intervenção foram se diversificando, sendo criada, ao longo dos anos 2000 por Gilles Monceau, a Socioclínica Institucional. Esta utiliza de alguns princípios da Socioanálise, contudo, não tem a pretensão da rapidez que a intervenção socioanalítica possui, podendo valerse de vários encontros para deflagrar processos analíticos, além de declarar objetivamente a intenção de produzir conhecimento a partir dos processos interventivos (MONCEAU, 2013).

A Socioclínica Institucional, abordagem teórica e metodológica utilizada no desenvolvimento desta obra, possui oito princípios que direcionam o processo de pesquisa e de análise. Elas não consistem em uma lista de regras a serem seguidas, mas em características que determinam a relação do pesquisador com seu objeto de pesquisa. Tais princípios são: análise da encomenda e das demandas; participação dos sujeitos no dispositivo; trabalho dos analisadores; análise das transformações que ocorrem à medida que o trabalho avança; aplicação de modalidades de restituição; intenção da produção de conhecimentos; atenção aos contextos e às interferências institucionais e; trabalho das implicações primárias e secundárias (MONCEAU, 2013).

A encomenda consiste no pedido oficial de intervenção feito pela direção de uma organização $^{11}$ e é o que deflagra o processo interventivo. Ela também pode surgir para o pesquisador a partir das demandas provenientes da realidade do trabalho. Já as demandas,

\footnotetext{
${ }^{11}$ Termo utilizado na Análise Institucional e que corresponde à materialização das instituições sob a forma de um organismo, uma entidade, assumindo uma configuração mais complexa ou mais simples (BAREMBLITT, 2012).
} 
correspondem aos desejos singulares dos participantes do grupo que se pretende trabalhar e estas sofrem mudanças com o passar da intervenção (L’ABBATE, 2012). Ambas necessitam ser analisadas no coletivo e são elas que sustentarão a problematização (MONCEAU, 2013), pois se tratam daquilo que aparece, que é identificado, ou seja, que diz sobre o que se encontra instituído.

A participação dos sujeitos no dispositivo já diz, por si só, aquilo que se espera com essa característica. Seja aceitando a ser observado em uma pesquisa de campo, seja resistindo a tal participação, é necessário colocar em análise as diferentes formas de participação dos sujeitos nos dispositivos (MONCEAU, 2013).

Já com relação ao analisador, é interessante observar o impasse existente com relação à criação e desenvolvimento desse termo. Ele foi criado por Félix Guatarri e publicado pela primeira vez por esse autor em 1974, no livro Psychanalise et Transversalité: Essais d'Analyse Institutionnelle (GUATARRI, 2004). Mas Georges Lapassade utilizou do mesmo termo em 1971, publicando-o em seu livro intitulado L'analyseur et l'analyste, mas remetendo a Guatarri enquanto criador, sem citar alguma obra específica deste como referência. Contudo, de fato, podemos dizer que Lapassade desenvolveu a ideia do analisador ao propor analisar a posição do analista na sociedade e diante dos analisadores, percorrendo pela (im)possibilidade do analista exercer controle sobre os analisadores (LAPASSADE, 1971).

Em seguida, René Lourau incorporou os analisadores à Socioanálise, trazendo a ideia de que eles correspondem àquilo que, devido certas circunstâncias, se tornam reveladores de algo que se encontrava latente, possuindo o efeito de "revelar a estrutura da organização, provocá-la, forçá-la a falar" (LOURAU, 2014). O analisador é responsável por "revelar algo que permanecia escondido, de desorganizar o que estava de certa forma organizado, de dar um sentido diferente a fatos já conhecidos" (L'ABBATE, 2004, p. 82). Ou seja, “tudo aquilo que apoia a análise das dinâmicas institucionais, independente da modalidade de trabalho socioclínico" é analisador (MONCEAU, 2013, p. 98).

Eles podem ser classificados em analisadores naturais e analisadores construídos. Os analisadores naturais, como o próprio nome diz, são aqueles que aparecem naturalmente a partir do processo interventivo (ex.: a transferência em um atendimento psicanalítico). Já os analisadores construídos são aqueles previamente elaborados (ex.: sala, divã, poltrona, horários, regras, etc.) (LAPASSADE, 1971) e que também podem trazer a tona questões a serem analisadas. Ambos possuem o objetivo de fazer a instituição falar por meio daquilo que se encontra instituído (LOURAU, 2014). 
Com o avançar da intervenção socioclínica são esperadas transformações tanto na condução da intervenção em si quanto no trabalho desenvolvido pelas pessoas em processo de análise. Assim, a análise das transformações que ocorrem à medida que o trabalho avança são os efeitos e materiais do trabalho socioclínico. Há que se integrar a análise dos diversos efeitos (individuais, coletivos, institucionais) do trabalho socioclínico ao dispositivo utilizado nos encontros, incorporando processos de reflexão tanto do analista quanto do grupo como um todo (MONCEAU, 2013).

As modalidades de restituição consistem em "produzir oportunidades para aprofundar ou para questionar as análises, ou mesmo reconsiderar a orientação do próprio dispositivo de trabalho" (MONCEAU, 2013, p. 100). Não consistem em fornecer uma simples informação, mas um movimento de retomada a acontecimentos, em geral, excluídos ou banalizados. Durante as intervenções, procura-se reservar um período para o processo de restituição, podendo ocorrer múltiplas restituições dentro de um processo interventivo (LOURAU, 1993).

Um dos diferenciais da Socioclínica Institucional perante à Socioanálise consiste na declaração objetiva da intenção de produzir conhecimento. Não que a Socioanálise não tenha essa pretensão, afinal, René Lourau e Georges Lapassade produziram uma gama de livros e artigos a partir de reflexões e intervenções realizadas por eles, além de estarem inseridos no meio universitário enquanto docentes. Contudo, a Socioclínica Institucional declara essa intenção objetivamente, introduzindo-a dentre os seus princípios.

A produção de conhecimentos não diz respeito apenas ao conhecimento científico e acadêmico, mas também aos significados que as intervenções produzem nos diferentes locais e regiões. Estes, articulados a outras observações, podem ser capazes de possibilitar a construção de análises ainda mais abrangentes (MONCEAU, 2013).

Com relação às interferências institucionais, estas dizem respeito ao que as diversas instituições exercem na realização de uma intervenção socioclínica, pois esta se encontra sempre situada no meio de uma interferência institucional (MONCEAU, 2013). Por vezes, tais interferências são imperceptíveis e passam despercebidas, podendo não ser identificadas e analisadas enquanto, por exemplo, um analisador potente para o processo interventivo.

A implicação consiste em um dos princípios da Socioclínica Institucional (e também da Socioanálise) e corresponde a um dos conceitos que René Lourau veio trabalhando durante toda sua vida profissional. Se buscarmos seu significado no dicionário português online, obteremos "ato ou efeito de implicar(-se); aquilo que está na mente, mas não foi expresso; subentendido, sugestão; ato ou efeito de envolver-se; comprometimento; envolvimento; ligação" (MICHAELIS, 2017). No dicionário francês online, o termo implication corresponde ao 
“estado de alguém que é implicado nos seus afazeres; quem é implicado por alguma coisa; consequência esperada" (LAROUSSE, 2017, tradução livre do autor ${ }^{12}$ ).

Se pudéssemos atribuir algum sinônimo para as definições acima listadas, certamente utilizaríamos engajamento como uma delas. E, correntemente, ouvimos e utilizamos a expressão "estar implicado com..." no sentido de querer quantificar o quão engajado, comprometido, envolvido o sujeito se encontra em/com determinada atividade ou trabalho. Contudo, para a Análise Institucional, implicação possui outro sentido.

Trata-se de um termo herdado da Psicoterapia Institucional de François Tosquelles e Jean Oury que faziam uso dos conceitos freudianos de transferência e contratransferência institucionais em suas intervenções. Contudo, Lourau utilizava esses conceitos a nível sociológico, dizendo que a estrutura da organização está sujeita a transferência de todas as pessoas que dela fazem parte e não apenas de um sujeito que ocupa determinado lugar específico dentro dela (LOURAU, 2014).

Portanto, a implicação, para a Análise Institucional, foi desenvolvida a partir da análise crítica que Lourau fez aos estudos de Freud sobre as multidões. Ele se opõe ao fato de Freud dizer que a estrutura libidinal é a chave das relações entre os grupos e as instituições, sustentando que a questão central consiste no vínculo social que os sujeitos estabelecem entre si e com as instituições (MARTIN, 2014). Ele a define como:

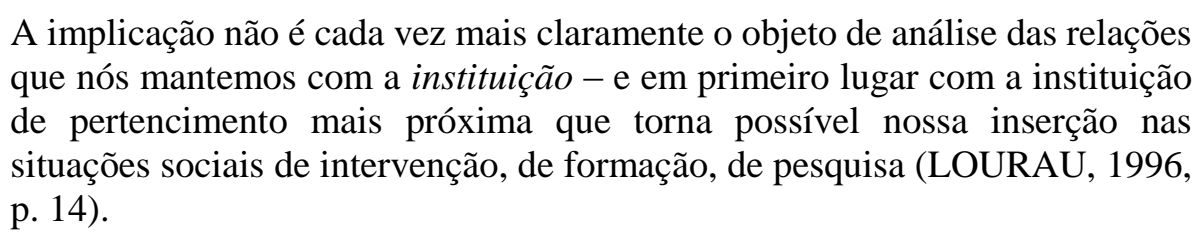

Tomando por referência a definição simplificada (mas não simplista) adotada por Monceau (2008b) e retomada por Penido (2015), a implicação nada mais é que a relação que os sujeitos estabelecem com as instituições. Ela não se dá apenas a nível libidinal, mas também a nível ideológico e organizacional (MONCEAU, 2012).

Barbier (1985) ao tratar do conceito de implicação nas pesquisas em ciências humanas, fala de três dimensões ${ }^{13}$ que a compõe: psicoafetiva (libidinal), histórico-existencial (ideológica) e estrutural-profissional (organizacional).

\footnotetext{
12 «État de quelqu'um qui est impliqué dans une affaire ; ce qui est impliqué par quelque chose ; conséquence attendue » (LAROUSSE, 2017).

${ }^{13}$ O texto de Barbier (1985) traduzido para o português utiliza a terminologia "Níveis de Abordagem". Contudo, por compreender a implicação enquanto algo dinâmico, sem superposições e por se tratar de um texto que tivemos acesso apenas à tradução, adotaremos a terminologia "Dimensões de Abordagem", visto tal terminologia ter sido utilizada dessa forma em outras produções do mesmo autor.
} 
A dimensão libidinal está relacionada com o desejo dos sujeitos. Este, segundo Guatarri e Rolnik (1996, p. 232), "tende a questionar a ideia de que o desejo e a subjetividade estariam centrados nos indivíduos e resultariam, no plano coletivo, da interação de fatos individuais". Consiste, portanto, na concepção do desejo no campo social.

Dentro da pesquisa, Barbier diz que "o objeto de investigação sempre questiona os fundamentos da personalidade profunda. Aliás, toda profissão baseada no desenvolvimento de uma relação humana especial supõe esse tipo de implicação" (BARBIER, 1985, p. 108). Lourau (1993) diz que as implicações libidinais, os afetos homossexuais e heterossexuais estão presentes em qualquer situação da vida, o tempo todo.

A dimensão ideológica está bastante articulada à libidinal e faz menção àquilo que os sujeitos acreditam. Para Marx, “a ideologia passa a ser o sistema das ideias, das representações que domina o espírito de um homem ou um grupo social. E isto só é possível quando se completa a divisão social do trabalho material e espiritual". Portanto, a ideologia não consiste em algo consciente e individual, mas algo produzido a partir da existência social dos sujeitos (GARCIA, 1988). É justamente porque o pesquisador está totalmente engajado no aqui e agora de sua pesquisa, no presente e no projeto dos grupos dos quais ele conduz, que ele não pode escapar a essa implicação (BARBIER, 1985).

A dimensão organizacional, como o próprio nome sugere, diz respeito à base material que o sujeito se encontra. Ela é, por excelência, a dimensão da mediação e consiste "na procura dos elementos que têm sentido com referência ao trabalho social do pesquisador e ao seu enraizamento sócio-econômico na sociedade contemporânea” (BARBIER, 1985, p. 117).

Portanto, somos movidos o tempo todo por nossas implicações libidinais, ideológicas e organizacionais, não havendo como negar a existência da implicação. "Ter consciência de sua existência colabora para o melhor entendimento da forma como atuamos como analistas institucionais" (L'ABBATE, 2012, p. 201). O pesquisador que analisa suas implicações no grupo, possibilita transformações a ele mesmo e ao grupo, não obtendo a ideia de alguém que vai resolver os problemas do grupo e tampouco deixar de resolver seus próprios problemas e questionamentos (BARBIER, 1985).

Trazendo para o contexto da pesquisa, é possível identificar dois tipos de implicação: a primária que diz respeito às implicações do pesquisador dentro da situação de intervenção e a secundária que se refere às implicações do pesquisador no campo de análise ${ }^{14}$ da pesquisa (MONCEAU, 2013; SANTANA, 2016).

\footnotetext{
${ }^{14}$ Campo de análise consiste no sistema de referência teórica adotado pelo pesquisador que opera dentro de uma situação de pesquisa (LOURAU, 1997).
} 
Nessa direção e a partir de intervenções realizadas por meio de análise institucional das práticas sociais ${ }^{15}$, Gilles Monceau define a implicação profissional como "o conjunto de relações que o sujeito estabelece com a profissão (pensada como instituição com sua dinâmica própria) à qual ele pertence, e com as outras instituições nas quais, ou em ligação às quais, ele exerce sua profissão" (MONCEAU, 2012, p. 19, tradução livre do autor ${ }^{16}$ ).

Considerando o trabalho em saúde enquanto uma instituição, por possuir normas e regras pré-estabelecidas, a implicação profissional nada mais seria que a relação que os sujeitos (profissionais de saúde, usuários dos serviços de saúde, apoiadores de humanização, articuladores de EPS, etc.) estabelecem com o trabalho em saúde. O enfermeiro possui uma relação com o trabalho a ser desenvolvido na ESF. Ele pode amar o que faz, gostar, não gostar, ser indiferente (implicação libidinal), acreditar nas ações executadas por ele e por sua equipe, não acreditar ser um bom modelo de atenção à saúde (implicação ideológica), ter respaldo da gestão para o bom desenvolvimento de suas funções, conseguir desenvolver o trabalho pactuado em equipe (implicação organizacional). Portanto, ele permanece implicado com o trabalho em saúde, quer queira quer não.

Aquilo que impede o processo de análise da implicação corresponde à sobreimplicação (MONCEAU, 2008b). Ela é "a ideologia normativa do sobretrabalho, gestora da necessidade do implicar-se" (LOURAU, 2004, p. 190) e responsável por anestesiar os efeitos de nossas questões libidinais, ideológicas e organizacionais nas situações que participamos, burlando a própria implicação (ROMAGNOLI, 2014).

Diante disso, para um pesquisador deflagrar processos de análises coletivas, é necessário que ele possua consciência do coeficiente de transversalidade dentro do processo analítico. Transversalidade, assim como analisador, também foi um termo criado por Félix Guatarri e indica uma dimensão que pretende superar os dois impasses, o de uma pura verticalidade (existente, por exemplo, em uma estrutura piramidal de um organograma) e o de uma simples horizontalidade (retrato de relações que se estabelecem de forma mais ou menos informal e institucional nos degraus da pirâmide) dentro de um processo interventivo (GUATARRI, 2004; LOURAU, 2014).

A transversalidade tende a acontecer quando há uma comunicação máxima entre os diferentes níveis e nos mais diversos sentidos. Portanto, é possível modificar os diferentes

\footnotetext{
${ }^{15}$ Corresponde a uma das modalidades de intervenção da Socioclínica Institucional (MONCEAU, 2012).

16 « L'implication professionnelle est l'ensemble des relations que le sujet entretient avec la profession (pensée comme une instituition ayant sa dynamique propre) à laquelle il « appartient » et avec les autres instituitions dans lesquelles ou en lien avec lesquelles il exerce sa profession » (MONCEAU, 2012, p. 29).
} 
coeficientes de transversalidade existentes dentro de um grupo de maneira inconsciente, sendo que o processo analítico efetivo somente ocorrerá a partir de um nível de transversalidade entre seus membros (GUATARRI, 2004).

Além disso, e em se pensando na relação sujeito-objeto, pesquisador-objeto de pesquisa, interventor-grupo de intervenção, René Lourau fez uso de um conceito desenvolvido por Simondon e denominado de transdução. Ela é diferente de indução (onde o sujeito diz acerca do todo) e de dedução (onde o todo diz do sujeito) (LOURAU, 1997). A transdução corresponde a uma operação que se realiza por meio da composição e não da negação (como acontece na dialética), contendo todos os termos iniciais na resolução da tensão, conservando e integrando aspectos opostos (ARAGON, 2014).

Como no espectro de cores, os dois pólos extremos são periféricos; são finais, limites. É a partir do centro (o verde-amarelo) que se sucedem, fundindo uma a outra, as diversas cores localizáveis, designáveis. Este movimento, seguido de potencializações e de atualizações, é a transdução (LOURAU, 1997, p. 4, tradução livre do autor ${ }^{17}$ ).

A posição do analista institucional deve ocorrer, portanto, no intermédio do excesso de luz (que não o cegue) e do excesso de sombra (capaz de escurecer sua visão). Trata-se de intervir na perspectiva do 'vir entre' (vir, subjuntivo do verbo ver), pois só assim o socioanalista ou socioclínico poderá acolher o não saber, tanto em relação ao grupo quanto em relação a si mesmo (L'ABBATE, 2012).

Portanto, partimos da premissa da inexistência de imparcialidade do autor na construção do seu objeto de estudo e na entrada em seu campo de intervenção, compreendendo que o seu estar no mundo e sua relação com as instituições interferem diretamente em sua forma de pensar, agir e elaborar a produção que aqui se encontra. Exemplo disso consiste no próprio fato do autor principal dessa obra assumir suas implicações com a Saúde Coletiva, com a Saúde Pública, com o apoio desde o início. Nesse sentido, apresentamos adiante, parte do percurso teórico percorrido por ele para chegar ao problema de pesquisa propulsor dessa produção.

\footnotetext{
17 «Comme dans le spectre des couleurs, les deux pôles extrêmes sont périphériques ; ce sont des termes, des limites. C'est à partir du cente (le vert-jaune) que se succèdent en se fondant les unes dans les autres les diverses couleurs localisables, désignables. Ce mouvement, suite de potentialisations et d'actualisations, est la transduction » (LOURAU, 1997, p. 4).
} 


\section{O PROCESSO DE FORMAÇÃO EM SAÚDE NO BRASIL: ALGUNS ELEMENTOS}

Para darmos início a este ato, será necessário situarmos o leitor acerca da nossa concepção de formação.

Adotamos a mesma ideia de Giorgio Agamben (2009, p. 9) de que "a terminologia é o momento poético do pensamento". Nesse sentido, o significado da palavra formação consiste no ato, efeito ou modo de formar algo; constituição; modo de criar uma pessoa, forjando-se seu caráter, sua personalidade e sua educação; criação; a educação acadêmica de um sujeito, incluindo-se os cursos concluídos e os títulos obtidos (MICHAELIS, 2017).

Acreditamos que nossa concepção se aproxima pouco da descrição trazida pelo dicionário. Diríamos que a aproximação se dá no "ato, efeito ou modo de formar", por atribuir movimento e dinamismo ao verbo. Contudo, compreendemos formação, assim como Passos e Carvalho (2015), enquanto uma forma de ação, onde se assume, inclusive, uma postura política ao agir.

A forma de ação do sujeito é fruto das diversas conexões que ele estabelece com o mundo e daquilo que ele carrega consigo. Trata-se de algo dinâmico, em constante movimento, pois a cada momento o sujeito se conecta com algo ou com o outro e se forma (e forma o outro), adotando uma ação modificada a partir desse encontro. Consiste, então, em um processo.

A partir de então, adentramos ao processo histórico da formação em saúde no Brasil, pois compreendemos esse fenômeno enquanto um processo em composição que está intimamente ligado a sua historicidade, podendo fornecer pistas com relação aos rumos que a formação em saúde poderá tomar, apesar dos diversos atravessamentos ${ }^{18}$ que ela se encontra sujeita durante esse percurso.

O ensino superior iniciou no Brasil com a chegada da família real portuguesa, em 1808, sendo aqui instaladas duas escolas médicas, uma na cidade de Salvador e outra na cidade do Rio de Janeiro. A partir de 1832, essas mesmas universidades passaram a oferecer, além da educação médica, a educação farmacêutica. Após mais de oito décadas e já na Primeira República do Brasil, em 1890, houve a criação da primeira Escola de Enfermagem no país, diante da necessidade da existência de outros profissionais de saúde que atuassem no controle

\footnotetext{
18 Atravessamento consiste na conservação de algo previamente existente, levando à manutenção do instituído. Quando em situação analítica, os atravessamentos são responsáveis por dificultarem o processo de análise (ROCHA; DEUSDARÁ, 2010).
} 
epidemiológico nacional, diminuindo as morbidades por doenças transmissíveis e pelas guerras. (CECCIM; CARVALHO, 2006).

Durante a primeira metade do século XIX, predominava mundialmente o modelo francês de formação médica. Esse modelo, denominado anatomoclínico, pressupunha o aprendizado do estudante ao lado do leito do paciente, cabendo o aprendizado de técnicas diagnósticas e terapêuticas nos anfiteatros anatômicos dos hospitais e a realização de pesquisas clínicas na faculdade de Medicina. Já durante a segunda metade do mesmo século, esse modelo começa a sofrer influências, sobretudo, do modelo de pesquisa médica alemã, centrado no laboratório, na hierarquia, na especialização e nas pesquisas experimentais (KEMP; EDLER, 2004; PAGLIOSA; DA ROS, 2008).

Foi na segunda metade do século XIX que Florence Nightingale e 38 mulheres treinadas por ela partiram para os campos de guerra, onde organizaram um hospital com cerca de 4000 soldados internados e baixaram a mortalidade local de $40 \%$ para $2 \%$, adotando, basicamente, estratégias de valorização do ambiente adequado para o cuidado, divisão social do trabalho em enfermagem e autoridade sobre o cuidado a ser prestado, determinando o nascimento da enfermagem moderna. Tal marco institucionaliza a enfermagem enquanto profissão, atribuindo um processo de formação para que isto ocorresse, sendo criada a primeira escola de enfermagem na Inglaterra, em 1860 (PADILHA; MANCIA, 2005).

Em 1905, Léonie Chaptal começa a preparação do território francês com o intuito de criar uma "Casa-escola", sensibilizando homens e mulheres para a necessidade de existência de uma formação de enfermeiras que fosse mais sólida. Ela é tida como a arquiteta da profissão de enfermagem na França, correspondendo a uma mulher que fez uso de suas influências políticas para alcançar e garantir a formação de enfermeiras no país (DIEBOLT, 2012).

Diante dos diversos contextos de transformações, no século XX inicia a priorização ao uso de recursos com alta densidade tecnológica e medidas profiláticas para o cuidado em saúde, tais como a imunização, o saneamento e o controle de vetores no enfrentamento aos problemas de saúde da população, centrando a atenção aos componentes vinculados à patologia e à fisiopatologia em detrimento das questões sociais e singulares dos sujeitos (PAIM; ALMEIDA FILHO, 1998). Esse período é caracterizado pela ênfase dada às ciências biológicas e ao rigor científico no cuidado e nas pesquisas em saúde, podendo ser comprovado pela publicação do Relatório Flexner ${ }^{19}$ em 1910.

\footnotetext{
${ }^{19}$ Abraham Flexner (1866-1959) foi um administrador norte americano de descendência alemã. Elaborou esse relatório conhecido mundialmente a partir de um estudo de avaliação de 155 escolas de Medicina dos EUA e Canadá no período de 180 dias (PAGLIOSA; DA ROS, 2008).
} 
Esse relatório, cheio de controvérsias com relação as suas leituras e interpretações (ALMEIDA FILHO, 2010), legitimou a racionalidade da medicina moderna, incluindo aspectos relacionados à formação com ênfase nas características biológicas, no mecanicismo das práticas assistenciais, na especialização do conhecimento, na negação do saber popular e de outras práticas de cuidado, na cura e medicalização da sociedade e na centralização da atenção à saúde nos serviços hospitalares (PEREIRA; LAGES, 2013).

Empiricamente falando, ele propunha um modelo de formação em saúde pautado no estudo do ser humano por meio de recortes de órgãos e sistemas, dando enfoque à dimensão biológica do organismo na tentativa de compreender o adoecimento. Foi nesse contexto que surgiram os Hospitais Universitários, enquanto estabelecimentos potentes para o desenvolvimento da pesquisa e do ensino (CECCIM; CARVALHO, 2006; AZEVEDO et al., 2013).

Contudo, vale destacar que em 1920, ou seja, dez anos após a publicação do Relatório Flexner, era publicado o Relatório Dawson na Inglaterra, que propunha uma formação em saúde integrada ao sistema de saúde e não, exclusivamente, aos hospitais enquanto campo de ensino e habilitação profissional. Ele enfatizava a integração entre atividades preventivas e curativas, o olhar direcionado às práticas de atenção básica e não à atenção especializada, usando a rede de serviços enquanto escola e não somente os hospitais. Essas características influenciaram diretamente a constituição do sistema nacional de saúde inglês ao final de 1940 (CARVALHO; CECCIM, 2016).

Tal fato compõe o que denominamos de processo de institucionalização da formação em saúde, que está sempre permeada por movimentos e forças diversas, mas que se encontra em permanente processo de (re)construção. Vai ao encontro da inexistência de uma linearidade exata em que os fenômenos acontecem (normalmente retratados por meio dos períodos ou anos), mas que estes ocorrem entremeados por diversas forças que podem ser contrárias, a favor, que tangenciam e que interferem, diretamente, no processo de institucionalização.

Além disso, é relevante apontar que o modelo flexneriano não influenciou somente os currículos dos cursos de medicina, mas também dos demais cursos da área da saúde no Brasil (NUNES, 2010), consolidando um modelo de ensino fragmentado, disciplinar, com enfoque na especialidade, hospitalocêntrico, normatizante, centrado na lógica de mercado, com maior investimento em práticas curativas e dependente de equipamentos e aparelhos para a sua execução (CECCIM; CARVALHO, 2006; AZEVEDO et al., 2013). 
A formação em saúde passou a resultar em uma "colcha de retalhos", costurada com base em uma concepção de corpo destituído de alma e desarticulado de outros corpos, pura natureza, de comportamento supostamente invariável e explicável cientificamente pelas ciências naturais (CARVALHO; CECCIM, 2016, p. 6).

Na mesma época de divulgação do relatório Dawson na Inglaterra, Léonie Chaptal, na França, propôs a regulamentação nacional do exercício da profissão de enfermagem, procurando contar com a aprovação dos meios popular, político, administrativo, religioso e médico. Ela chega a citar Florence Nightingale em um documento de vinte páginas que teve o intuito de decretar os programas e as escolas de formação em enfermagem. Contudo, o fez com algumas reservas. Além disso, esse decreto também possibilitou a obtenção do diploma de estudos em enfermagem por meio da formação realizada no período de dois anos. Porém, era um diploma que não tinha obrigatoriedade para o exercício da profissão no país, naquele momento (DIEBOLT, 2012).

Outra pessoa que também exerceu alguma influência na realidade francesa foi Desiré Bourneville, médico que, após retornar de uma visita à escola de Florence Nightingale, na Inglaterra, percebeu a necessidade de se formar as enfermeiras francesas (ROTHIERBAUTZER, 2012).

Toda essa conjuntura deu início ao processo de profissionalização da enfermagem francesa impulsionado, sobretudo, pela luta política dos socialistas franceses contra as congregações religiosas, buscando afastá-las dos hospitais (ROTHIER-BAUTZER, 2012).

Enquanto isso, no Brasil, vivia-se a reforma sanitária dos anos 1920, cujas bases ideológicas advinham do nacionalismo e do higienismo, em meio a um contexto de crise social, mobilização da classe trabalhadora e de debates em torno dos problemas de higiene e de saúde pública. As bases ideológicas que sustentavam a reforma impulsionaram para a substituição da ação em saúde pública centrada no modelo de polícia sanitária pelo de educação sanitária. Nesse contexto, o país, por meio do apoio político e financeiro da Fundação Rockefeller, passou a investir na qualificação de trabalhadores e na estruturação da força de trabalho de enfermagem (MASCARENHAS; MELO; SILVA, 2016; PEREIRA; PEDRO, 2013).

Só na década de 1940 que o Brasil vive a expansão dos cursos de saúde, sob influência do modelo norte-americano de ensino superior, dando início a um processo de departamentalização das escolas, agrupando cadeiras de ensino, aumentando a quantidade de laboratórios, de reformas e de construções. Contudo, cabe lembrar que, em contrapartida, a Organização Mundial de Saúde (OMS) lançou, nessa mesma década, um novo conceito de saúde baseado no "bem-estar físico, mental e social", ampliando a concepção de saúde para 
além das características biológicas do sujeito, mas estabelecendo uma relação com as humanidades e com as determinações socioeconômicas, fornecendo indícios para a necessidade de uma reformulação do ensino na saúde (CARVALHO; CECCIM, 2016).

Isso reafirma novamente que o processo de institucionalização acontece por meio de diversas forças. No caso supracitado, ao mesmo tempo em que existiram forças de segregação da formação, pautada em blocos específicos de conhecimento, houve também o lançamento da concepção de saúde, pela OMS, vinculada a uma lógica muito mais de composição de diversas frentes e fatores (sociais, econômicos, biológico, mensal, etc.) que de segregação dos mesmos.

O período que vai de 1922 a 1950, representa o momento de introdução dos departamentos de Medicina Preventiva ${ }^{20}$ nas escolas médicas dos Estados Unidos e do Canadá, impulsionados pela Medicina Social inglesa. Foi nesse período que a Organização PanAmericana da Saúde (OPAS) junto às instituições formadoras se mobilizaram em prol de refletirem acerca do ensino da saúde pública nos cursos de saúde, buscando pensar acerca da atitude dos professores, integrar os currículos e relacionar o ensino ao sistema de saúde com o intuito de melhor formar os profissionais, além de adequar a participação na melhoria das condições de saúde da população (CECCIM; CARVALHO, 2006).

Durante as décadas de 1950 e 1960 o mundo todo vive o movimento preventivista, que enfoca as responsabilidades individuais e da família sobre as questões de saúde da população, inserindo uma nova forma de conceber saúde, delimitando as condições determinantes das doenças que devem ser estudadas, além do espaço de atuação dos profissionais da saúde diante desse contexto (AROUCA, 1975; CECCIM; CARVALHO, 2006).

Esse movimento apontou para a necessidade de reconfigurar o processo de formação em saúde que deveria estar voltado às necessidades de saúde da população, à proteção dos ambientes de vida e trabalho, ao desenvolvimento da educação popular em saúde e não à doença enquanto objeto, à internação hospitalar e à prestação de procedimentos técnicos como únicos meios de atenção à saúde (CECCIM; CARVALHO, 2006).

Ele chega ao Brasil na década de 1950, deixando sua marca por meio da criação de departamentos de Medicina Preventiva na Faculdade Paulista de Medicina e na Faculdade de Medicina de Ribeirão Preto. O argumento para a criação desses departamentos foi para que se tornassem espaços de promoção de mudança na formação em saúde, possibilitando a formação de docentes, ensinando os princípios da medicina preventiva com o intuito de formar médicos

\footnotetext{
${ }^{20}$ Utilizaremos o termo Medicina Preventiva (em maiúsculo) ao referirmos aos departamentos, estabelecimentos que foram criados com o intuito de colocarem em prática o ensino dos princípios e das concepções da medicina preventiva (em minúsculo), que se trata de uma nova concepção de pensar o cuidado em saúde.
} 
que possuíssem outra concepção de medicina (OFICINA SANITÁRIA PANAMERICANA, 1957).

Foi nesse contexto, de repensar as práticas de formação dos profissionais de saúde, que o método da Aprendizagem Baseada em Problemas (ABP) ou Problem Based Learning (PBL) foi visto como uma possibilidade de formar profissionais de saúde que atendessem a uma nova concepção de cuidado, ou seja, centrada nas concepções da medicina preventiva. Assim, algumas Universidades, no final dos anos 60, adotaram a ABP/PBL enquanto método de ensino, sendo Maastrich, na Holanda, e McMaster, no Canadá as pioneiras (CONTERNO, 2013; 2016).

Considerando essas constatações, é possível indicar que o movimento da medicina preventiva gerou um movimento no campo pedagógico, ao propor uma metodologia de ensino alternativa, sugerindo a aprendizagem ativa como a forma mais adequada para a formação profissional em saúde, além de indicar a necessidade da revisão do papel dos docentes (CONTERNO, 2013, p. 44).

Foram realizados vários encontros e seminários internacionais com foco na temática da formação em saúde e foi, nesse processo, que a medicina preventiva assumiu a forma de um movimento social, difundindo-se em uma rede com uma dinâmica de influências, visando despertar e reforçar consciências (AROUCA, 1975).

Em 1968 ocorre a Reforma Universitária (Lei 5.540/68) que institui, oficialmente, o modelo norte-americano de ensino nos cursos de medicina e de saúde no Brasil. Consistiu em um processo de departamentalização e fragmentação do ensino sendo que este ficou dividido em dois ciclos, um de disciplinas básicas - o ciclo básico - e outro de disciplinas profissionalizantes. Contudo, essas disciplinas pouco se interagiam, mesmo fazendo parte de um mesmo departamento (LAMBERT, 2002).

Nessa época, vale ressaltar que o Brasil se encontrava em período ditatorial (19641985), vivendo o "milagre econômico" no início desse período, mas seguido por um processo de recessão com altos índices de desemprego, inflação e pobreza. Foi o momento em que o Ministério da Saúde era tido como órgão máximo de controle e condução das políticas públicas de saúde do país, construindo um grande complexo médico-hospitalar de características privada, médico centrado, com enfoque na medicalização.

Existiu, portanto, um processo de fortalecimento da produção privada de serviços de saúde e sua reorganização em moldes tipicamente empresariais. Além disso, assistiu-se também a um estímulo à atividade médica especializada, através de sua remuneração diferenciada e de seu privilegiamento na atividade assistencial (FEUERWERKER, 1998, p. 45). 
Tais concepções caminhavam na contramão daquilo que estava sendo debatido e estabelecido no II Plano Decenal de Saúde das Américas, que ocorreu em 1972, em Santiago, na III Reunião Especial de Ministros da Saúde das Américas. Além de reforçar o I Plano Decenal - estabelecendo a saúde enquanto estratégia prioritária para o desenvolvimento econômico - também previa questões ligadas à ecologia, saúde materno infantil, alimentação, participação da comunidade na organização e execução de programas de saúde e os recursos humanos para a saúde (ORGANIZACIÓN PANAMERICANA DE LA SALUD, 1973).

Especificamente com relação aos trabalhadores de saúde, o Plano reafirmou a necessidade de profissionais, tanto técnicos quanto de nível superior, para a execução de uma atenção integral á saúde. Além disso, recomendou uma formação de profissionais generalistas, apontando para o fato de que os enfermeiros e auxiliares de enfermagem consistiam em peças fundamentais para a prestação de cuidado em saúde nos países em desenvolvimento, recomendando o maciço investimento na formação desses profissionais. Além dos enfermeiros e auxiliares de enfermagem, o Plano indicava para a necessidade de uma distribuição racional de médicos especialistas por toda extensão territorial dos países, visando obter um maior aproveitamento do tempo de trabalho deles (CONTERNO, 2013; 2016).

Ainda, o II Plano Decenal de Saúde das Américas recomendou a Integração Docente Assistencial (IDA) como estratégia pedagógica que visasse aproximar o ensino à realidade com o intuito de incorporar um processo de formação pautada nas necessidades dos serviços de atenção à saúde. Assim, os serviços contribuiriam com a formação e se beneficiariam dela e as Universidades se incorporariam autenticamente ao desenvolvimento dos serviços, promovendo o bem estar da população (ORGANIZACIÓN PANAMERICANA DE SALUD, 1973). Essas ideias serão retomadas mais tarde, no desenrolar da década de 1990, momento em que a integração ensino-serviço adquire um enfoque mais robusto.

Contudo, apesar da existência de um processo ditatorial no país que se encontrava avesso aos movimentos de mudança na formação em saúde, eram perceptíveis estratégias de resistência ${ }^{21}$ ao autoritarismo do Estado no campo da saúde por meio da inflexão aos modelos médico centrado e hospitalocêntrico, em prol da luta pela redemocratização no campo das práticas em saúde. Tais estratégias impulsionaram para a configuração do início do movimento

\footnotetext{
${ }^{21}$ A resistência pode ser colocada em análise enquanto analisador das contradições institucionais (MONCEAU, 1997). A análise pelas resistências perpassa por três momentos dialéticos que são: a) defensivo: movimento em direção do desaparecimento do poder; b) ofensivo: movimento em direção da construção de um novo poder; c) integrativo: momento direcionado ao desaparecimento da resistência (ela é reprimida e permanece latente) (DOBIES; L'ABBATE, 2016).
} 
da reforma sanitária, no final da década de 1970, que viria a edificar as bases de criação do SUS (PASSOS; CARVALHO, 2015).

O movimento da reforma sanitária brasileira requeria a construção de uma política de saúde que fosse democrática e que alcançasse, efetivamente, a melhoria das condições de vida da população. O grande marco desse movimento e da história na organização do sistema público de saúde brasileiro se deu por meio da $8^{\text {a }}$ Conferência Nacional de Saúde (CNS), ocorrida em março de 1986. Foi nessa Conferência - a primeira aberta à sociedade - que foi criado o Sistema Único Descentralizado de Saúde (SUDS) que viria a se tornar o SUS e que se discutiu acerca da "interdependência entre política social e econômica e a conceituação dos serviços de saúde como públicos e fundamentais para a população" (CONTERNO, 2013, p. 109). Além disso, um dos maiores legados dessa Conferência foi a construção das bases para a seção Da Saúde na Constituição Federal Brasileira de 1988, definindo saúde enquanto direito de todos e dever do Estado (BRASIL, 1993; CONTERNO, 2013).

Portanto, podemos dizer que o SUS consiste em um produto do processo de institucionalização da saúde coletiva brasileira. Ele é formado por meio de forças instituintes de resistência ao modelo de atenção à saúde instituído - e se institucionaliza enquanto SUS um produto do processo de forças instituintes e da saúde pública instituída. Somado a isso e tendo o SUS enquanto representante da instituição saúde pública brasileira pós 1988, dizemos que este se encontra em permanente processo de institucionalização, sendo (re)construído diariamente.

No que tange à formação em saúde, a década de 1990 foi marcada pelos projetos de integração ensino-serviço. Os projetos UNI "abriram caminhos de mudança nas reformas curriculares, desafiando a mudança de conteúdos para além da saúde pública preventivista, mediante a integração ensino-serviço-comunidade" sendo sistematizados e implementados na América Latina juntamente com os projetos de integração docente-assistencial (IDA), culminando com a estruturação da Rede UNI-IDA (mais tarde Rede Unida) (CARVALHO; CECCIM, 2016, p. 150).

Refletindo e analisando criticamente os projetos UNI, Lins e Cecílio (1998) apontaram para algumas limitações na composição desses projetos no que tange a Universidade (diversos e potentes micropoderes existentes, interesses corporativos presentes nesse espaço, a cultura de produção do saber, etc.), os serviços (resistência das corporações do setor, hegemonia do modelo médico-liberal, etc.) e a participação da comunidade (disputa política dos diversos grupos, as diferenças na participação, o atraso conceitual sobre participação, etc.), interferindo 
diretamente na execução dos mesmos, mas não deixando de gerar desterritorializações (LINS; CECÍLIO, 1998).

Desterritorialização “como 'quebra do chão conhecido', perda de referências que estão instituídas e fazem da realidade uma superfície 'denominada', conhecida, familiar, unívoca, plana e monofônica (...). Territorialidade é um conjunto de referências instituídas" (FORTUNA, 2003, p. 5). Consiste em sair do território protegido, ou seja, da zona de conforto. Esse movimento de desterritorialização não é, em si, um ponto de chegada, mas um processo de criação de novos territórios (PAULON; ROMAGNOLI, 2010).

Ainda com relação à formação em saúde e no que concerne às CNS, Conterno (2013) realizou uma análise das CNS e apontou que a preocupação com o processo de formação em saúde foi abordado desde a $1^{\text {a }}$ CNS. Ela distingue tais abordagens em três momentos: $1^{\circ}$ ) 1941 1963 - abrange as três primeiras CNS e a temática da formação em saúde foi direcionada à formação escolar, com a figura do médico enquanto protagonista da atenção á saúde, reforçando a relevância do profissional técnico no processo de cuidado. $2^{\circ}$ ) 1967-1980 - abrange da $4^{\mathrm{a}}$ à $7^{\mathrm{a}}$ CNS e coincide com o período ditatorial no país. A formação dos profissionais de saúde não foi debatida enquanto algo direcionado à solução de problemas de saúde, mas enquanto instrumento decisivo da política desenvolvimentista do país, capacitando sujeitos para o trabalho, visando o aumento da produtividade em busca da superação do atraso econômico. $3^{\circ}$ ) 1986-1992 - abrange as $8^{a}$ e $9^{a}$ CNS apontando para elementos que extrapolam a formação em saúde, trazendo também as condições de atuação profissional, a valorização e a organização dos trabalhadores dentro do sistema de saúde.

Enquanto desdobramentos da $8^{\mathrm{a}} \mathrm{CNS}$, deram início às Conferências Nacionais de Recursos Humanos para a Saúde (CNRHS). Na $1^{\mathrm{a}}$, foram discutidas questões vinculadas à preparação e formação de pessoal, avaliação de desempenho, recrutamento e seleção de profissionais, dentre outras pautas, valendo destacar para o fato da extrapolação da agenda aos assuntos concernentes apenas à formação profissional, abrangendo também as condições de atuação profissional nos serviços de saúde. A $2^{\text {a }}$ foi responsável pela regulamentação do artigo 200, inciso III, da Constituição Federal, que delega ao SUS a competência de ordenar a formação de recursos humanos para a saúde (BRASIL 1993; 1994).

Contudo, os relatórios da $8^{\mathrm{a}} \mathrm{CNS}$ e das CNRHS não mencionam fundamentos pedagógicos necessários à formação técnica, ética e política dos profissionais de saúde. Esse esvaziamento vem sendo preenchido, desde o início da década de 1990, por meio de projetos que, inclusive, impulsionaram para a configuração e aprovação, entre 2001 e 2004, das 
Diretrizes Curriculares Nacionais (DCN) ${ }^{22}$ dos cursos de graduação em saúde; e, na década de 2000, por políticas como a Política Nacional de Educação Permanente em Saúde (PNEPS), a $\mathrm{PNH}$, dentre outras, que se pautam em uma síntese epistemológica composta por elementos da educação para a transformação social de Paulo Freire; da aprendizagem significativa de David Ausubel; dentre outras orientações do movimento da Escola Nova ${ }^{23}$ (PEREIRA; LAGES, 2013). Tratam-se de iniciativas instituintes que visam desterritorializar o lugar da formação em saúde hegemonicamente instituído.

Portanto, podemos dizer que, com relação à formação em saúde, esta ainda carece de uma orientação que integre o ensino ao trabalho, voltada para uma formação teórico-conceitual e metodológica que potencialize competências para a integralidade, incluindo o enfrentamento das necessidades de saúde da população e desenvolvimento do SUS. Ainda, o ensino na saúde possui, hegemonicamente, um formato conteudista, com uma pedagogia de transmissão, de desconexão entre núcleos temáticos, com excesso de carga horária para determinados conteúdos em detrimento de outros, desvinculando o ensino da pesquisa e da extensão, predominando um formato enciclopédico orientado pela doença e pela reabilitação (CARVALHO; CECCIM, 2016).

Dentre os aspectos relevantes para confrontar a universidade hoje há o questionamento quanto ao espaço e tempo disponibilizados para a criatividade, quanto à flexibilidade nos seus ordenamentos e quanto à integração dos conhecimentos, aspectos fundamentais para a formação de profissionais 'pensantes' - objetivo insubstituível da universidade (CARVALHO; CECCIM, 2016, p. 137).

Nesse contexto, adentraremos aos dois próximos atos onde trataremos, especificamente, da EPS enquanto política de formação dos profissionais de saúde para o SUS, adotada pelo Ministério da Saúde (MS) e que procura colocar o cotidiano do trabalho em análise, garantindo reflexão e sentidos produzidos pelo/para trabalhador, resultando na melhoria das ações prestadas à população; e da PNH enquanto política que abarca uma gama de dispositivos a serem colocados em prática em prol do aperfeiçoamento da atenção à saúde prestada à população e da gestão dos serviços de saúde, dando um maior enfoque para o apoio institucional enquanto um desses dispositivos.

\footnotetext{
${ }^{22}$ A DCN dos cursos de graduação em saúde (exceto Medicina Veterinária, Psicologia, Educação Física e Serviço Social) afirma que "a formação profissional de saúde deve contemplar o sistema de saúde vigente no país, o trabalho em equipe e a atenção integral à saúde" (CARVALHO; CECCIM, 2016, p. 152).

${ }^{23}$ A Escola Nova consistiu em um movimento de renovação do ensino que ganhou força no século XX. A principal característica desse movimento consiste em atribuir um impulso ao estudante para que ele possa desenvolver autonomia para o desenvolvimento dos próprios estudos.
} 


\section{A EdUCAÇÃo PERMANENTE EM SAÚde ENQUANTO POLÍtica de FORMAÇÃO DE PROFISSIONAIS PARA O SUS}

A Educação Permanente consiste em um princípio de uma estratégia de formação em vista de uma nova sociedade (FURTER, 1977).

Segundo Paulino et al. (2012), o termo Educação Permanente (EP) foi utilizado, pela primeira vez, por Pierre Furter, educador francês, em um projeto de reforma do ensino que tinha a tarefa de continuar a formação fora da escola. Contudo, o próprio Pierre Furter diz sobre o desconhecimento da história de criação da EP, referindo que ela já aparece no início do século XX no relatório A. L. Smith sobre a educação dos adultos, publicado em 1919 na Inglaterra (FURTER, 1977).

Assim, parece-nos mais razoável afirmar que a ideia da EP foi produzida na Europa, no início do século XX, sendo amplamente divulgada no cenário internacional na década de 1960 por meio, principalmente, das produções de Pierre Furter (FEUERWERKER, 2014).

Na mesma década foi realizada a $15^{\text {a }}$ Conferência Geral da Organização das Nações Unidas para a Educação, a Ciência e a Cultura (UNESCO), que elegeu o ano de 1970 como o "Ano Internacional da Educação", com o objetivo de mobilizar energias e inspirar iniciativas em educação e treinamento, perpassadas pelos princípios da educação em seu sentido mais amplo e direcionada a todos os sujeitos, independente de sua idade. Além disso, essa Conferência apontou também para a preocupação quanto à natureza e os resultados da educação, sobretudo, da contribuição para o desenvolvimento econômico, social, de direitos humanos e da necessidade de um enfoque prático na promoção da reflexão, nas decisões dos governos e das organizações internacionais sobre os meios concretos que possibilitam a melhoria e expansão da educação (UNESCO, 1968).

\footnotetext{
A educação ganha centralidade para se discutir e planejar ações no espectro de programas da UNESCO, sediada em Paris, e de seus estados membros. Constata-se que a partir desse período houve um boom de publicações em francês sobre a temática da educação e da educação permanente (SCHOTT, 2013, p. 37).
}

Segundo Furter (1974, 1977), a EP possui três razões que favoreceram sua ampla divulgação a partir da década de 1960: antropológica, socioeconômica e política.

No que tange às razões antropológicas, a EP está intimamente vinculada à crítica realizada pela antropologia contemporânea da existência de um homem prematuro (a criança e o adolescente que devem estar em processo de aprendizagem) e de um homem maduro (o adulto 
que sabe), compreendendo o ser humano enquanto um ser inacabado e sempre em processo de formação. As razões socioeconômicas fazem menção à relação existente entre a formação recebida e sua utilização efetiva na prática profissional. E, por fim, com relação às razões políticas, essas correspondem ao processo de democratização da sociedade pós-industrial, vislumbrando o aumento da participação dos cidadãos nos processos de decisão, em busca de uma maior flexibilização do poder (FURTER, 1977).

Essas razões parecem convergir com os movimentos/teorias que fundamentaram a EPS incorporada pela PNEPS. A EPS foi criada a partir de um diálogo entre as ideias de Paulo Freire, as proposições da Escola Nova e do construtivismo, da Análise Institucional e demais movimentos de mudança na formação dos profissionais de saúde (CECCIM, 2005a). Portanto, fizemos algumas articulações: as razões antropológicas e políticas muito se aproximam dos princípios da educação de jovens e adultos, da formação como um processo de transformação social e enquanto algo que aconteça de maneira dialógica, capaz de problematizar e superar os processos formativos conservadores (FREIRE, 2008). As razões socioeconômicas dialogam com a concepção construtivista que está intimamente associada, sobretudo, ao movimento escola-novista e à aprendizagem significativa proposta por David Ausubel, caracterizada pela interação cognitiva entre o conhecimento prévio e o novo conhecimento que o sujeito adquire (AUSUBEL, 1978). E as razões políticas, novamente, se aproximam um tanto das proposições feitas pela Análise Institucional, sobretudo, no que tange à produção de autoanálise e autogestão nos coletivos de trabalho (BAREMBLITT, 2012).

A EP "não é nem um movimento nem uma doutrina unitária, mas um ponto de encontro de diferentes correntes de pensamento, de intenções diversas e mesmo de objetivos divergentes" (FURTER, 1977, p. 76). Tal afirmação, mais uma vez, nos remete ao arcabouço que fundamenta a EPS dentro da PNEPS, que possuem, em seu cerne, divergências epistemológicas, mas que se articulam na fundamentação do que vem a ser a EPS para a PNEPS (FEUERWERKER, 2014; CECCIM, 2005a).

Compreendemos por EPS:

O ato de colocar o trabalho em análise, as práticas cotidianas em análise, as articulações formação-atenção-gestão-participação em análise. Não é um processo didático-pedagógico, é um processo político-pedagógico; não se trata de conhecer mais e de maneira mais crítica e consciente, trata-se de mudar o cotidiano do trabalho na saúde e de colocar o cotidiano profissional em invenção viva (em equipe e com os usuários). A escolha pela "educação permanente em saúde" é a escolha por novas maneiras de realizar atividade, com maior resolutividade, maior aceitação e muito mais compartilhamento entre os coletivos de trabalho, querendo a implicação profunda com os usuários dos sistemas de saúde, com os coletivos de formulação e 
implementação do trabalho, e um processo de desenvolvimento setorial por “encontro" com a população (CECCIM, FERLA, 2006, p. 110).

Dessa forma, podemos afirmar que a EPS e a EP possuem duas características em comum: 1) serem compostas por um aglomerado de teorias/ideias/movimentos que se diferem epistemologicamente; 2) possuírem o objetivo de uma formação, que se pretende crítica e reflexiva, posterior àquela obtida na escola/universidade.

Contudo, tanto a EP quanto a EPS podem ser erroneamente utilizadas segundo uma lógica centralizada na mudança quantitativa das práticas profissionais, visando apenas a melhoria da qualidade do trabalho prestado. Refletindo, criticamente, acerca dessa possibilidade, é possível perceber certa ambiguidade tanto na EP quanto na EPS, pois ao mesmo tempo em que elas podem justificar estratégias de exploração de mão de obra, indo ao encontro do aumento das exigências requeridas pela alta produtividade, podem também representar uma promoção profissional e social enquanto condição operária. Ou seja, consideramos que o alerta feito por Furter (1977), da dicotomia entre a necessidade de aprender mais, não para viver melhor, mas para produzir mais, se estende da EP para a EPS.

Que o trabalho em saúde necessita de um processo de aperfeiçoamento contínuo em prol da melhoria da assistência prestada à população é inegável. Contudo, há que se refletir acerca da lógica em que se tem pensado, idealizado, programado e colocado em prática as atividades de EPS. Esta tem buscado apenas o atendimento de uma demanda de melhoria quantitativa do trabalho em saúde prestado à população e/ou priorizado o desenvolvimento do profissional enquanto um sujeito inserido em um contexto político, econômico e social?

Schott (2013) em sua tese de doutorado fez uso da definição de EPS feita por Ceccim e Ferla (2006) e de uma construção teórica bastante densa acerca da trajetória da EPS a partir da EP e apontou para o fato de que a EPS, conforme definição adotada pelo MS na composição da PNEPS, possui uma lógica que não está direcionada ao desenvolvimento do sujeito no sentido de que ele "aprenda a ser", mas possui um enfoque maior para uma mudança das práticas profissionais e melhoria quantitativa do trabalho, atendendo a uma lógica neoliberal, ou seja, capitalista.

Contudo, pelo próprio arcabouço teórico que fundamenta a EPS adotada pelo MS na composição da PNEPS, seria difícil afirmar que a mesma tenha uma conotação voltada para a lógica mercadológica e capitalista. Compreendemos que a qualificação do trabalho prestado pelos profissionais corresponde ao resultado do processo de EPS e não o objetivo a ser tomado a priori para o processo de formação no/para o trabalho. 
Optou-se por priorizar a educação dos profissionais de saúde como uma ação finalística da política de saúde e não a atividade-meio para o desenvolvimento da qualidade do trabalho. Este é o aspecto original, o diferencial de novidade configurado sob o conceito político-pedagógico da Educação Permanente em Saúde (CECCIM, 2005b, p. 976).

Tomando a ideia da micropolítica do trabalho em saúde, ou seja, dos espaços que são atravessados pelas diversas disputas, conflitos e intencionalidades e que compõem uma determinada lógica de território onde se produzem conexões sociais, onde afetos e desejos se manifestam e também onde se produz o cuidado em saúde (MERHY, 2007), acreditamos que a EPS possua a intenção de, a partir da problematização desses territórios, vislumbrar a autonomização dos sujeitos, que passarão a exprimir seus pontos de vistas acerca da organização do processo de trabalho em saúde, do cuidado que é prestado e da forma como este é feito.

As bases epistemológicas que compõem a EPS pautada pela PNEPS vislumbram não apenas um olhar reflexivo para as ações do trabalho, mas também a emancipação desse sujeito a partir do seu processo de aprendizagem (FREIRE, 2008). Somado a isso, sabemos que todos os sujeitos se encontram implicados, consciente ou inconscientemente, com as instituições que os atravessam cotidianamente (LOURAU, 2004) e analisar essas implicações consiste em um processo que, por si só, desloca, movimenta, gera desterritorializações, indo além de apenas qualificar o trabalho em si.

Mas as reflexões e análises apontadas por Schott (2013) podem fazer sentido ao analisarmos o contexto político-econômico de surgimento da EPS. Ela surgiu na década de 1980, sendo disseminada pela OPAS em um cenário de mudanças mundiais, onde a saúde passava também a entrar nas agendas de prioridades dos organismos internacionais, reconhecendo a área enquanto um mercado promissor a ser explorado pelo capital. Foi a partir de 1984 que a OPAS deu início à formação de grupos de trabalho compostos por experts de diversos países da América Latina, tendo como objetivo desenvolver novos conceitos para o processo de formação profissional (LEMOS, 2010).

Foi nesse momento, inclusive, que passaram a adotar EPS ao invés de Educação Continuada (EC) no âmbito das atividades formativas desenvolvidas pela OPAS:

Uma alternativa para o desenvolvimento de processos educativos do tipo permanente, que utilizem o trabalho como eixo de aprendizagem. Utilizará, portanto, de aqui em diante, a denominação "educação permanente" para 
referirmos ao modelo de trabalho que esta proposta expõe (OPAS, 1988, p. 6, tradução livre do autor ${ }^{24}$ ).

Por EC compreende-se a execução de ações pontuais, com características de treinamento, vinculadas à atualização técnica e científica. Utilizam de metodologias tradicionais de ensino que apresentam mais uma característica de transmissão do conhecimento que de construção coletiva do mesmo. Normalmente, é composta por um planejamento prévio e longitudinal (MONTANHA; PEDUZZI, 2010).

Contudo, essa diferenciação entre EC e EPS não é unânime entre os autores na OPAS, existindo alguns que consideram esses termos como sinônimos e outros que os diferem (LEMOS, 2010).

Nessa direção, identificamos tais divergências, relacionadas à concepção de EPS, também nas produções científicas publicadas a partir de 2003 (ano de publicação dos "Caminhos para a mudança da formação e desenvolvimento dos profissionais de saúde: diretrizes para a ação política para assegurar Educação Permanente em Saúde”, documento precursor da PNEPS) e 2004 (ano de publicação da Portaria que instituiu a PNEPS como estratégia do SUS para a formação e o desenvolvimento de trabalhadores da saúde) (BRASIL, 2003, 2004).

De início, é notória a grande produção acerca dessa temática vinculada à enfermagem e por enfermeiros. Exemplo disso consiste no próprio fato do autor principal e de sua orientadora serem enfermeiros e pesquisarem acerca dessa temática. Compreendemos que esse protagonismo de enfermeiros na produção científica acerca de EC e EPS se dá pelo fato da profissão de enfermagem se encontrar embutida de ações educativas em todas as suas dimensões, somado ao contínuo processo de ocupação de espaços de formação por essa categoria profissional.

Realizamos uma revisão integrativa de literatura, buscando responder ao seguinte questionamento: Qual a concepção de educação permanente em saúde pela enfermagem brasileira? Adotamos enquanto critérios de inclusão: 1) artigos que tratam da realidade brasileira e que foram publicados no período de 2003 a 2016;2) disponíveis nos idiomas português, inglês e espanhol; 3) produção científica completa, disponível online e 4) pesquisa científica que aborde a concepção de EPS pelo(s) autor(es). Foram excluídos deste estudo

\footnotetext{
${ }^{24}$ una alternativa para el desarrolo de procesos educativos de tipo permanente, que utilicen el trabajo como eje del aprendizage. Se utilizara, en consecuencia, de aqui en adelante, la denominacion "educación permanente" para referinos al modelo de trabajo que dicha propuesta expone (OPAS, 1988, p.6).
} 
dissertações, teses, artigos de revisão de literatura, estudos de caso, ensaios, reflexão teórica e entrevistas.

Enquanto estratégia de busca, foi utilizada a Biblioteca Virtual em Saúde com todas as suas bases de dados, dentre elas a Literatura Latino-Americana e do Caribe em Ciências de Saúde (LILACS), o Medical Literature Analyses and Retrieval System online (MEDLINE) e a Base de Dados de Enfermagem (BDENF). Foi empregado o descritor controlado Enfermagem em associação com o descritor "sinônimo" Educação Permanente, nos idiomas português, inglês e espanhol, combinados por meio do operador booleano AND. Vale precisar que, por mais que existam os termos Educação Continuada ou Educação Permanente no título de alguns artigos, não, necessariamente, estes puderam ser contemplados nessa revisão, por não possuírem tais termos dentre os seus descritores. A busca foi realizada no período de Março à Abril de 2016.

Os estudos encontrados foram criteriosamente avaliados, procedendo-se a seleção daqueles que se enquadravam nos critérios de inclusão e que possuíam relação com a questão estabelecida nesta revisão integrativa, sendo excluídos os demais.

Elaboramos um instrumento com o intuito de facilitar a identificação e análise dos dados dos estudos incluídos, composto pelos seguintes itens: 1) O texto traz a definição de EPS para o(s) autor(es)?; 2) Qual é a definição utilizada? e 3) O texto traz a participação da enfermagem em processos de EPS?

Foram encontrados 885 arquivos, sendo que, após a aplicação dos critérios de inclusão e exclusão por meio da leitura dos títulos e/ou resumos, resultaram 31 artigos que foram selecionados para a leitura na íntegra. Após a leitura e utilização do instrumento facilitador da identificação e análise dos dados, foram excluídos outros 09 artigos. Assim, foram incluídos nessa revisão integrativa 22 artigos científicos. 
Tabela 1 - Referências dos artigos excluídos da revisão integrativa com os respectivos motivos de exclusão

\begin{tabular}{|c|c|c|}
\hline $\mathbf{N}^{\mathbf{o}}$ & Referências dos Artigos Selecionados & Motivo \\
\hline 1 & $\begin{array}{l}\text { Lima SG, Macedo LA, Vidal ML, Sá MPBO. Educação permanente em SBV e } \\
\text { SAVC: impacto do conhecimento dos profissionais de enfermagem. Arquivo } \\
\text { Brasileiro de Cardiologia. 2009; 93(6): 630-636 }\end{array}$ & $\begin{array}{l}\text { Não define } \\
\text { educação } \\
\text { permanente }\end{array}$ \\
\hline 2 & $\begin{array}{l}\text { Braga AT, Melleiro MM. Analysis of the continuing education of a teaching } \\
\text { hospital in the perception of the nursing team. Online brazilian journal of } \\
\text { nursing. 2009; } 8(2): 1-7\end{array}$ & $\begin{array}{l}\text { Não define } \\
\text { educação } \\
\text { permanente }\end{array}$ \\
\hline 3 & $\begin{array}{l}\text { Medeiros AC, Pereira QLC, Siqueira HCH, Cecagno D, Moraes CL. Gestão } \\
\text { participativa na educação permanente em saúde: olhas das enfermeiras. 2010; } \\
63(1): 38-42\end{array}$ & $\begin{array}{l}\text { Não define } \\
\text { educação } \\
\text { permanente }\end{array}$ \\
\hline 4 & $\begin{array}{l}\text { Souza RCR, Soares E, Souza IAG, Oliveira JC, Salles RS, Cordeiro CEM. } \\
\text { Educação permanente em enfermagem e a interface com a ouvidoria hospitalar. } \\
\text { Revista Rene Fortaleza. 2010; 11(4): } 85-94\end{array}$ & $\begin{array}{l}\text { Não enfoca a } \\
\text { enfermagem } \\
\text { em processos } \\
\text { de EPS }\end{array}$ \\
\hline 5 & $\begin{array}{l}\text { Silva LAA, Franco GP, Leite MT, Pinno C, Lima VML, Saraiva N. Concepções } \\
\text { educativas que permeiam os planos regionais de educação permanente em saúde. } \\
\text { Texto Contexto Enfermagem. 2011; 20(2): 340-348 }\end{array}$ & $\begin{array}{l}\text { Não enfoca a } \\
\text { enfermagem } \\
\text { em processos } \\
\text { de EPS }\end{array}$ \\
\hline 6 & $\begin{array}{l}\text { Ezequiel MCDG, Noel BK, Lemos PP, Paiva AC, Borges LP, Ferreira GM, } \\
\text { Sanzovo OS. Estudantes e usuários avaliam ferramenta de educação permanente } \\
\text { em saúde - Sieps. Revista Brasileira de Educação Médica. 2012; 36(Supl. 2): } \\
112-130\end{array}$ & $\begin{array}{l}\text { Não enfoca a } \\
\text { enfermagem } \\
\text { em processos } \\
\text { de EPS }\end{array}$ \\
\hline 7 & $\begin{array}{l}\text { Silva CT, Terra MG, Roso CC, Souto VT. Educação permanente em saúde: } \\
\text { percepção de profissionais de uma residência multidisciplinar. Revista } \\
\text { Enfermagem UFSM. 2013; 3(Esp.): 627-635 }\end{array}$ & $\begin{array}{l}\text { Não enfoca a } \\
\text { enfermagem } \\
\text { em processos } \\
\text { de EPS }\end{array}$ \\
\hline 8 & $\begin{array}{l}\text { Backes DS, Obem MK, Pereira SB, Gomes CA, Backes MTS, Erdmann AL. } \\
\text { Incubadora de aprendizagem: ferramenta indutora do empreendedorimos na } \\
\text { Enfermagem. 2015; 68(6): } 1103-1108\end{array}$ & $\begin{array}{l}\text { Não define } \\
\text { educação } \\
\text { permanente }\end{array}$ \\
\hline 9 & $\begin{array}{l}\text { Rodrigues ACS, Vieira GLC, Torres HC. A proposta da educação permanente } \\
\text { em saúde na atualização da equipe de saúde em diabetes mellitus. Revista Escola } \\
\text { de Enfermagem USP. } 2010 ; 44(2): 531-537\end{array}$ & $\begin{array}{l}\text { Relato de } \\
\text { experiência }\end{array}$ \\
\hline
\end{tabular}

Fonte: Biblioteca Virtual em Saúde (2016) 
Tabela 2 - Referências dos artigos selecionados para análise na revisão integrativa

\begin{tabular}{|c|c|c|}
\hline $\mathbf{N}^{\mathbf{0}}$ & Referências dos Artigos Selecionados & Ano \\
\hline 1 & $\begin{array}{l}\text { Ricaldoni CAC, Sena RR. Educação permanente: uma ferramenta para pensar e agir no } \\
\text { trabalho de enfermagem. Revista Latino-Americana de Enfermagem. 2006; 14(6): s/p }\end{array}$ & 2006 \\
\hline 2 & $\begin{array}{l}\text { Carneiro MS, Silva RFG, Cruz TCA, Ferreira ES. Educação permanente em saúde no } \\
\text { desenvolvimento organizacional do serviço de enfermagem da fundação santa casa de } \\
\text { misericórdia do Pará. 2006; 20(4): } 35-39\end{array}$ & 2006 \\
\hline 3 & $\begin{array}{l}\text { Paschoal AS, Mantovani MF, Méier MJ. Percepção da educação permanente, continuada e } \\
\text { em serviço para enfermeiros de um hospital de ensino. Revista Escola de Enfermagem USP. } \\
\text { 2007; 41(3): 478-484 }\end{array}$ & 2007 \\
\hline 4 & $\begin{array}{l}\text { Silva AM, Peduzzi M. Caracterização das atividades educativas de trabalhadores de } \\
\text { enfermagem na ótica da educação permanente. Revista Eletrônica de Enfermagem. 2009; } \\
\text { 11(3): 518-526 }\end{array}$ & 2009 \\
\hline 5 & $\begin{array}{l}\text { Lino MM, Backes VMS, Ferraz F, Prado ML, Fernandes GFM, Silva LAA, Kloh D. } \\
\text { Educação permanente dos serviços públicos de saúde de Florianópolis, Santa Catarina. } \\
\text { Trabalho Educação Saúde. 2009; } 7(1): 115-136\end{array}$ & 2009 \\
\hline 6 & $\begin{array}{l}\text { Peduzzi M, Guerra DAD, Braga CP, Lucena FS, Silva JAM. Atividades educativas de } \\
\text { trabalhadores na atenção primária: concepções de educação permanente e de educação } \\
\text { continuada em saúde presentes no cotidiano de Unidades Básicas de Saúde em São Paulo. } \\
\text { Interface Comunicação Saúde Educação. 2009; 13(30): 121-134 }\end{array}$ & 2009 \\
\hline 7 & $\begin{array}{l}\text { MH, Otenio CCM. Representação da participação do enfermeiro } \\
\text { as relações humanas do trabalho. Revista de Administração em } \\
0\end{array}$ & 2010 \\
\hline 8 & $\begin{array}{l}\text { Costa VZ, Cezar-Vaz MR, Cardoso LS, Soares JFS. Educação permanente no programa } \\
\text { saúde da família: um estudo qualitativo. Invest Educação Enfermagem. 2010; 28(3): 336- } \\
344\end{array}$ & 2010 \\
\hline 9 & $\begin{array}{l}\text { Balbino AC, Bezerra MM, Freitas CASL. Educação permanente com os auxiliares de } \\
\text { enfermagem da estratégia saúde da família em Sobral, Ceará. Trabalho Educação Saúde. } \\
\text { 2010; 8(2): } 249-266\end{array}$ & 2010 \\
\hline 10 & $\begin{array}{l}\text { Montanha D, Peduzzi M. Educação permanente em enfermagem: levantamento de } \\
\text { necessidades e resultados esperados segundo a concepção dos trabalhadores. Revista Escola } \\
\text { de Enfermagem USP. 2010; 44(3): 597-604 }\end{array}$ & 2010 \\
\hline 11 & $\begin{array}{l}\text { ni B, Carvalho BG, Nunes EFPA, Lepre RL, Mainardes P, Junior LC. A } \\
\text { nente em saúde como estratégia pedagógica de transformação das práticas: } \\
\text { limites. Trabalho Educação Saúde. } 2010 ; 8(2): 207-227\end{array}$ & 2010 \\
\hline & Jesus MCP, Figueiredo MAG, Santos SMR, Amaral AMM, Rocha LO, Thiollent MJM. & \\
\hline 12 & $\begin{array}{l}\text { Educação permanente em enfermagem em um hospital universitário. Revista Escola de } \\
\text { Enfermagem USP. 2011; 45(5): 1229-1236 }\end{array}$ & 2011 \\
\hline 13 & $\begin{array}{l}\text { Paulino VCP, Bezerra ALQ, Branquinho NCSS, Paranaguá TTB. Ações de educação } \\
\text { permanente no contexto da estratégia saúde da família. Revista Enfermagem UERJ. 2012; } \\
\text { 20(3): 312-316 }\end{array}$ & 2012 \\
\hline 14 & Leite MTS, Sena RR, Vieira MA, Mendonça JMG, Dias OV, Santos MIP, Souza LPS. & 2012 \\
\hline & $\begin{array}{l}\text { Perspectivas de educaçao permanente em saude no norte de Minas Gerais. Revista Mineira } \\
\text { de Enfermagem. 2012; 16(4): 594-600 }\end{array}$ & \\
\hline 15 & $\begin{array}{l}\text { Barbosa VBA, Ferreira MLSM, Barbosa PMK. Educação permanente em saúde: uma } \\
\text { estratégia para a formação dos agentes comunitários de saúde. Revista Gaúcha de } \\
\text { Enfermagem. } 2012 ; 33(1): 56-63\end{array}$ & 2012 \\
\hline 16 & $\begin{array}{l}\text { Silva CT, Terra MG, Mostardeiro SCTS, Ribeiro DB, Lavich CRP, Xavier M. Nucleus of } \\
\text { permanent education in nursing: perspectives in a teaching hospital. Journal of Research } \\
\text { Fundamental Care Online. 2013; 5(3): 114-121 }\end{array}$ & 2013 \\
\hline 17 & $\begin{array}{l}\text { Hetti LB, Bernardes A, Gabriel CS, Fortuna CM, Maziero VG. Educação } \\
\text { permanente/continuada como estratégias de gestão no serviço de atendimento móvel de } \\
\text { urgência. Revista Eletrônica de Enfermagem. 2013; 15(4): 973-982 }\end{array}$ & 2013 \\
\hline
\end{tabular}


18

8 prot

Salum NC, Prado ML. A educação permanente no desenvolvimento de competências dos profissionais de enfermagem. Texto Contexto Enfermagem. 2014; 23(2): 301-308 Viana DM, Araújo RS, Vieira RM, Nogueira CA, Oliveira VC, Rennó HMS. A educação permanente em saúde na perspectiva do enfermeiro na estratégia saúde da família. Revista de Enfermagem do Centro Oeste Mineiro. 2015; 5(2): 1658-1668

Peixoto LS, Pinto ACS, Izu M, Tavares CMM, Rosas AMMTF. Perception of nurses in relation to training services offered through the service of continuous education. Journal de Research Fundamental Care Online. 2015; 7(2): 2323-2335

Sade PMC, Peres AM. Desenvolvimento de competências gerenciais do enfermeiro: diretriz

21 para serviços de educação permanente. Revista Escola de Enfermagem USP. 2015; 49(6): 991-998

Paim CC, Ilha S, Backes DS. Permanent education in health in na intensive care unit: the perception of the nurses. Journal de Research Fundamental Care Online. 2015; 7(1): 20012010

Fonte: Biblioteca Virtual em Saúde (2016)

Foi possível identificar que, dentre os 22 artigos que se enquadraram nos critérios de inclusão dessa revisão integrativa, 03 se encontravam redigidos em língua inglesa e 19 em língua portuguesa. Além disso, 11 consistem em estudos vinculados à realidade hospitalar, 06 à APS (Unidades Básicas de Saúde e/ou Estratégia Saúde da Família), 01 ao atendimento móvel de urgência e emergência e outros 04 à questões específicas que fogem às classificações anteriores (01 direcionado à concepção de EPS por professores universitários e preceptores enfermeiros; 01 voltado à formação de articuladores de EPS, 01 trazendo um mapeamento de ações de EPS de um determinado território e 01 trazendo a concepção de coordenadores de EPS de um município).

Ainda, 17 produções (cerca de 77,27\%) consistem em pesquisas de abordagem qualitativa, existindo 3 pesquisas quanti-qualitativa e 2 pesquisas de abordagem apenas quantitativa.

Todas as produções citam, em algum momento, o conceito de EPS vinculado àquele trazido pela PNEPS. Contudo, é possível identificar certo equívoco acerca daquilo que é citado como sendo EPS e o que é relatado enquanto resultados de pesquisa científica em 07 produções. Não se trata, necessariamente, de uma vinculação da EPS a uma lógica que difere daquela apresentada pela PNEPS, mas de uma constatação de que os autores trazem relatos de ações que se enquadram mais em atividades de EC do que de EPS, utilizando, em vários momentos, termos como cursos de capacitação, atividades pontuais, aulas teóricas enquanto estratégias de desenvolvimento da EPS em ato.

Sob a ótica da Análise Institucional, podemos dizer que as produções científicas demonstram que, apesar de se anunciarem com perspectivas de mudança, conceitos e ferramentas de formação caracterizados, possivelmente, como instituintes, se vinculam às 
práticas instituídas quando de seu processo de institucionalização. Assim, as forças produtoras de um novo modo de fazer educação no trabalho são capturadas por aspectos instituídos, direcionados as formas mais tradicionais de se realizar ações educativas.

Esse modo instituído diz respeito à identificação de um problema ou tema, passagem de informações para categorias e crença num imaginário de multiplicação, em que o trabalhador que foi "capacitado" fará a multiplicação do aprendido para os colegas de trabalho. Todas essas práticas estão mais próximas da EC, utilizando de estratégias instituídas, sedimentadas e tradicionais como a realização de atividades de treinamento, aulas modulares, dentre outros enquadres. Isso evidencia que o processo de institucionalização é composto, tanto por forças instituídas quanto por forças instituintes, que se articulam dialeticamente.

Apenas 08 artigos foram classificados em coerência com a concepção de EPS adotada pela PNEPS e outros 07 artigos apresentavam uma concepção mais direcionada àquela da análise feita por Schott (2013), ou seja, iluminando a qualificação do trabalho prestado pelos profissionais em questão enquanto objetivo central das ações de EPS, caminhando na direção de uma lógica mais neoliberal.

Além disso, dentre os 22 artigos, 17 apresentam incoerência com a proposta da PNEPS no que tange à multiprofissionalidade na busca de ações interdisciplinares por meio das ações de EPS. Eles trazem relatos que abarcam o desenvolvimento de ações de EPS com apenas uma categoria profissional. Tal fato, pode coincidir com a própria incoerência provocada pelo objetivo desta revisão integrativa, que procura vincular, propositalmente, a EPS à Enfermagem, relacionando esses dois descritores. Contudo, a intencionalidade dessa incoerência perpassa, justamente, pela busca por explicitá-la nos trabalhos desenvolvidos e divulgados no meio científico, como foi o caso de quase $80 \%$ das produções aqui analisadas.

Em suma, apenas 02 produções demonstraram coerência com os pressupostos da PNEPS no que concerne ao exercício da EPS, contemplando a multiprofissionalidade em busca da execução de ações interdisciplinares e não propondo a qualificação do trabalho enquanto objetivo máximo do processo, mas permeado também pelas questões que envolvem a reflexão da prática e a aprendizagem com o trabalho enquanto estratégias de emancipação do trabalhador enquanto sujeito.

Assim, acreditamos que a análise feita por Schott (2013) possui uma vinculação mais voltada à lógica de EPS vinculada apenas à qualificação do trabalho que, especificamente, a adotada pela PNEPS. Lemos (2013) também percebe que a lógica de EPS existente na proposição da PNEPS é composta por novos contornos e desenhos, diferindo da proposição feita na divulgação realizada a partir da década de 1980 . 
A expectativa do Ministério da Saúde é de instituir relações orgânicas e permanentes, estabelecendo o compromisso dos gestores com a formação e dos formadores com o sistema, retirando a preparação de recursos humanos de seu lugar secundário para se tornar eixo central de ação no SUS (...) a PNEPS traz em seu cerne uma ideia de priorizar a educação no próprio SUS, o que, historicamente, estava em segundo plano e acontecida de forma fragmentada e pulverizada (LEMOS, 2013, p. 93).

Somado a isso, Ceccim (2005b) relata que a proposição de EPS difundida pela OPAS reconhecia apenas os princípios da aprendizagem significativa (AUSUBEL, 1978) enquanto capazes de produzir mudanças no cotidiano do trabalho em saúde. Contudo, a EPS proposta na política consistiu em um desdobramento de vários movimentos de mudança na formação dos profissionais da área, conforme já exposto, além do enfoque à atenção à saúde, à gestão setorial e ao exercício do controle social.

Nesse sentido, assim como Ceccim e Ferla (2006), Feuerwerker (2014), Lemos (2013), Mishima et al (2015), dentre outros autores, compreendemos a EPS não apenas enquanto um modelo pedagógico contra hegemônico de formação de profissionais de saúde, mas como uma proposta política de formação para o SUS, centrada na reflexão do trabalho pelos profissionais de saúde e na busca pela autonomização dos sujeitos na problematização de suas práticas.

Portanto, concordamos que a EPS consiste em um processo educativo que busca colocar o cotidiano do trabalho ou da formação em saúde em análise, permeabilizado pelas relações interprofissionais a partir da realidade e em prol da construção de coletivos para a reflexão e avaliação dos sentidos que os atos produzem no cotidiano do trabalho. Este, executado por equipe multiprofissional, em busca de ações interdisciplinares ou transdisciplinares na garantia da integralidade e continuidade da atenção à saúde da população e com a participação desta nos processos decisórios e formativos (BRASIL, 2004; CECCIM, 2005a).

Partimos da premissa de que o trabalho em saúde possui uma característica que abrange a atenção à saúde, a gestão, o ensino e o controle social, compondo o que é denominado por quadrilátero da formação em saúde (CECCIM; FEUERWERKER, 2004). Utilizamos da máxima de que o trabalho em saúde não deve se restringir apenas a atenção à saúde, pois é impossível admitir ou propor a captura do trabalho em saúde pautado pela lógica dos saberes e das práticas que são expressos por meio dos equipamentos e das técnicas em uso. Acreditamos que, em qualquer lugar onde se estabeleça o contato entre um trabalhador de saúde e um usuário, há a produção do processo de trabalho em saúde (MERHY, 1997).

Assim, a partir do momento em que compõe, formalmente, a PNEPS, instituída por meio da Portaria no 198/GM, tratamos, portanto, a EPS enquanto estratégia do SUS para o 
desenvolvimento e formação de trabalhadores para a saúde pública (BRASIL, 2004), ou seja, uma política de Estado construída por processos coletivos e estabelecida por meio de muitos debates, esforços e participação popular. "Política tem responsabilidade compartilhada de condução e de acompanhamento. Políticas resultam de lutas sociais, da sensibilidade de gestores e da seleção de modos de enfrentar realidades" (CECCIM, 2005b, p. 979).

Por meio da PNEPS foi possível ampliar a participação de novos atores (dentre eles representantes dos trabalhadores, usuários, educadores e estudantes) ao processo de negociação e decisão acerca da destinação de recurso para a formação profissional. A tentativa consistia em substituir uma forma de financiamento de projeto de educação para a saúde, pautada na descrição e no estabelecimento de convênios que contemplassem uma quantidade financeira destinada a cada unidade federativa, atendendo a uma nova forma para que os governos estaduais, municipais e instituições de ensino pleiteassem e conseguissem tais financiamentos (PINTO, FERLA, 2015).

Podemos dizer que a EPS, em um primeiro momento (década de 1980), atendeu a uma demanda neoliberal de formação profissional que visou, sobretudo, a melhoria da atenção à saúde, pois tal proposição compôs agendas de negociações em prol da ascensão econômica, política e social dos países. O Brasil acompanhou este processo, formulando e implementando políticas influenciadas pela lógica neoliberal, sobretudo, durante o governo do Fernando Henrique Cardoso (1995-2002), alcançando êxitos representados pelo controle inflacionário e pelo crescimento econômico desse período.

Contudo, a agenda proposta por esse presidente não foi capaz de superar os alarmantes níveis de desigualdade social. Ao contrário, o constante incentivo à iniciativa privada afastou ainda mais a população dos seus direitos sociais básicos. A pressão dos movimentos sociais e dos partidos de esquerda fez surgir como alternativa política a eleição do presidente Luís Inácio Lula da Silva em 2003; com ele, novos atores sociais (ou "militantes sociopolíticos", conforme denominados por Ceccim (2005b)) passaram a influenciar a construção de políticas públicas, atendendo à demandas de setores mais progressistas e preocupados com a inclusão e a superação da grande desigualdade social presente no país. Dentre essas políticas, destacamos a PNEPS. 
Colocar a Educação Permanente em Saúde na ordem do dia para o SUS pôs em nova evidência o trabalho da saúde, um trabalho que requer: trabalhadores que aprendam a aprender; práticas cuidadoras; intensa permeabilidade ao controle social; compromissos de gestão com a integralidade; desenvolvimento de si, dos coletivos, institucional e político da saúde, além da implicação com as práticas concretas de cuidado às pessoas e às coletividades, no ensino e na produção de conhecimento (CECCIM, 2005b, p. 977-979).

Uma política que se aproxima dos pressupostos da PNEPS no que tange a essas "mudanças no modo como se organiza o trabalho em saúde, apostando em diversas estratégias de interação não só com os gestores estaduais e municipais, mas também com trabalhadores e usuários, enfocando o processo de trabalho" (PINTO, FERLA, 2015, p. 83) e que também foi instituída enquanto política de Estado no mesmo ano é a PNH, que discutiremos no próximo ato. Ambas se encontram menos no o que fazer e mais no como fazer e para que fazer (PINTO, FERLA, 2015). "Cada uma a seu modo, propõem a (des)aprendizagem em serviço, onde ensinar e aprender se incorporam nos processos cotidianos de trabalho e nos problemas/fazeres/saberes que ali são apresentados" (VASCONCELOS et al, 2016, p. 985).

Contudo, daremos um enfoque maior ao apoio institucional que consiste em um dos dispositivos propostos pela PNH para o alcance de seus objetivos e que também consiste em uma aposta da PNEPS (PINTO, FERLA, 2015). A justificativa principal para esse enfoque se deve à função desempenhada pelos sujeitos que fizeram parte da pesquisa-intervenção que compõe essa produção, cabendo um maior detalhamento acerca das especificidades que envolvem o desenvolvimento do apoio em saúde. 


\section{AS POLÍticas NACIONAL E ESTADUAL DE HUMANIZAÇÃO E O APOIO INSTITUCIONAL}

Em 2003, a PNH foi instituída enquanto política de Estado. Também conhecida por HumanizaSUS, surgiu a partir da reflexão e necessidade de se implantar uma política que levasse em consideração os processos de mudança dos sujeitos na produção da saúde, valorizando a dimensão subjetiva e social em todas as práticas de atenção e gestão, fortalecendo o trabalho em equipe, atuando em rede colaborativa e fazendo uso da informação, comunicação, EPS e espaços de gestão para construir autonomia e protagonismo dos sujeitos e coletivos (BRASIL, 2003a).

Ela foi fruto da interlocução de programas e ações propagados pelo Ministério da Saúde e que tinham por objetivo a humanização enquanto a possibilidade de dar voz ao usuário e ao trabalhador de saúde. Exemplo disso foi o Programa Nacional de Humanização na Atenção Hospitalar (PNHAH) que tinha como centralidade a promoção de ações pautadas na dignidade, na ética, no respeito e na solidariedade (BRASIL, 2001).

Portanto, a PNH surgiu a partir de três demandas centrais que vieram da necessidade de: 1) enfrentar os desafios elencados pela sociedade com relação à qualidade do cuidado prestado à população; 2) redesenhar e articular iniciativas de humanização do SUS e 3) enfrentar os problemas vinculados à organização e gestão do trabalho no SUS (BRASIL, 2007).

A partir de então, já é possível identificarmos algumas semelhanças entre a PNEPS e a PNH. Ambas partem da realidade do trabalho em saúde na edificação de suas propostas, além de pautarem a participação da população assistida pelos serviços de saúde enquanto atores indispensáveis ao processo de planejamento, implementação e avaliação de suas ações. Somado a isso, o resultado das atividades de ambas, de alguma forma, culminará com a melhoria do trabalho a ser prestado à população. Diríamos ainda que, enquanto a PNEPS possui como foco a formação dos profissionais de saúde, a PNH tem em vista a gestão e a atenção à saúde prestada aos usuários dos serviços de saúde enquanto focos principais, utilizando, para isso, de um método, de princípios, diretrizes, ferramentas e dispositivos.

A PNH aposta em um método baseado na inclusão de trabalhadores, usuários e gestores na produção e gestão do cuidado e dos processos de trabalho em saúde. Ela possui enquanto princípios: a) a transversalidade, que vai ao encontro do conceito trazido pela Análise Institucional e que corresponde ao reconhecimento da existência de um "terceiro eixo que altera o padrão tradicional de comunicação organizado a partir dos eixos vertical e horizontal nas instituições de saúde: eixo vertical da hierarquização dos diferentes e o eixo horizontal que 
homogeneíza a comunicação na corporação dos iguais" (PASCHE, PASSOS, HENNINGTON, 2011, p. 4544); b) a indissociabilidade entre atenção e gestão, compreendendo que esta última interfere diretamente na primeira, ao mesmo tempo em que o cuidado não compete apenas à equipe de saúde, mas também à família e ao suporte de vida possibilitado ao sujeito; e c) o protagonismo, corresponsabilidade e autonomia dos sujeitos e coletivos, centrando-se no reconhecimento de cada membro para o bom andamento da gestão e da atenção à saúde (BRASIL, 2013).

Suas diretrizes centrais são: a) o acolhimento enquanto tecnologia ${ }^{25}$ do encontro realizada entre os sujeitos que cuidam e os que são cuidados, em prol da produção de uma atenção á saúde que seja compartilhada e pautada na corresponsabilização; b) a gestão democrática ou cogestão das organizações de saúde, dos processos de trabalho e de formação, da clínica e da saúde coletiva por meio do compartilhamento do poder, de decisões, orientados por princípios éticos e políticos; c) a clínica ampliada que procura avançar para além da alopatia e da racionalidade clínica centrada no saber biomédico, incluindo as dimensões sociais ao processo de cuidado em saúde; d) valorização do trabalho prestado pelos trabalhadores de saúde, garantindo sua efetiva participação nas decisões e valorizando e assegurando boas condições de trabalho a eles e e) a garantia dos direitos dos usuários na direção da produção de corresponsabilização pela efetivação do SUS e de seus princípios, envolvendo o acesso à informação, inclusão nas práticas de saúde, etc. (BRASIL, 2008; 2010).

Já os dispositivos, para a PNH, consistem em arranjos pelos quais se executa a política em ato. Alguns dispositivos têm sido colocados em prática na produção de saúde, envolvendo coletivos e visando promover mudanças nos processos de gestão e de atenção à saúde da população. Alguns deles são: grupos de trabalho de humanização (GTH); câmara técnica de humanização (CTH); colegiado gestor; sistemas de escuta qualificada para usuários e trabalhadores da saúde; visita aberta e direito à acompanhante; programa de formação em saúde do trabalhador (PFST); projeto terapêutico singular (PTS); acolhimento com classificação de risco; equipe de referência e equipe matricial; apoio institucional; etc. (BRASIL, 2008).

Antes de entrarmos nas particularidades do dispositivo do apoio institucional, exploraremos um pouco mais algumas diferenças identificadas no emprego de alguns termos

\footnotetext{
${ }^{25}$ Nessa produção, utilizamos tecnologia em saúde a partir da concepção e classificação feita por Merhy (2007) sendo: a) tecnologia leve: consiste nas tecnologias das relações, do vinculo, da gestão enquanto uma estratégia capaz de produzir coletivos democráticos; b) tecnologia leve-dura: consiste nos saberes estruturados como a clínica, a epidemiologia, o taylorismo, etc.; e c) tecnologia dura: consiste nos equipamentos como máquinas, normas, organogramas, etc.
} 
da PNH, em algumas produções tanto do Ministério da Saúde quanto da Secretaria de Estado da Saúde de São Paulo.

Alguns textos da PNH utilizam o termo "ferramenta" como sinônimo de diretrizes e/ou dispositivos. Um exemplo é o acolhimento que é colocado tanto como um dispositivo (BRASIL, 2013) quanto uma ferramenta pela PNH (BRASIL, 2008). Outro exemplo seria a clínica ampliada que, ao mesmo tempo, corresponde a uma diretriz da PNH (BRASIL, 2013), também é apresentada enquanto uma ferramenta teórica (BRASIL, 2008). Assim, vale-nos explanar um pouco mais acerca dos conceitos que envolvem esses termos, com o intuito de também objetivarmos o que vem a ser ferramenta e dispositivo nesta produção.

O dicionário define ferramenta como qualquer instrumento necessário para o desempenho de uma profissão ou enquanto um meio para se alcançar determinado objetivo (MICHAELIS, 2017).

Em Microfísica do poder, Gilles Deleuze em conversa com Michel Foucault acerca do que vem a ser teoria e prática, diz que:

Uma teoria é como uma caixa de ferramentas, nada tem a ver com o significante (...) é preciso que sirva, é preciso que funcione. E não para si mesma. Se não há pessoas para utilizá-la, a começar pelo próprio teórico que deixa então de ser teórico, é que ela não vale nada ou que o momento ainda não chegou (FOUCAULT, 1979, p. 42).

Merhy (1999) ao tecer um raciocínio sobre o ato de cuidar em saúde, relata que:

Sabemos, por experiências como profissionais e consumidores, que quanto maior a composição das caixas de ferramentas (que, aqui, é entendida como o conjunto de saberes que se dispõe para a ação de produção dos atos de saúde), utilizadas para a conformação do cuidado pelos trabalhadores de saúde, individualmente ou em equipes, maior será a possibilidade de se compreender o problema de saúde enfrentado e maior a capacidade de enfrentá-lo de modo adequado, tanto para o usuário do serviço quanto para a própria composição dos processos de trabalho (MERHY, 1999, p. 1).

Compreendemos, portanto, que ferramenta, para os autores supracitados, possui interlocução e pode ser definida enquanto algo (o saber, por exemplo) que possui um valor de uso e que possa ser utilizado em determinado contexto, a partir de alguma necessidade.

Fazendo um paralelo com o processo de trabalho em saúde, os instrumentos ou ferramentas utilizadas pelos profissionais de saúde correspondem, exatamente, no conhecimento, no saber, na força de trabalho e nos equipamentos utilizados por eles para a realização do cuidado. Trata-se de um processo, pois consiste na combinação do objeto, ou seja, da matéria-prima a ser trabalhada (o ser humano, no caso), dos meios/instrumentos e do produto 
do trabalho, que corresponde ao encontro entre o trabalhador, os meios e o usuário do serviço de saúde (MISHIMA, 2003).

Portanto, ferramenta não deixa de ser um instrumento necessário para o desempenho de uma profissão, se compreendermos instrumento não como um objeto ou algo físico, afinal, a ferramenta pode ser o próprio conhecimento. Além disso, diríamos que a ferramenta possui a conotação de um meio pelo qual é possível se alcançar determinado objetivo, sabendo que esse alcance pode (ou não) ocorrer durante o percurso da ação.

Findada a explanação acerca de ferramenta e adotando seu significado para essa produção a partir das contribuições de Gilles Deleuze, Emerson Merhy e fazendo um paralelo com o processo de trabalho em saúde, adentraremos à noção de dispositivo.

É interessante observar a grande quantidade de produções científicas que utilizam a palavra dispositivo sem, ao menos, defini-la. Giorgio Agamben (filósofo italiano contemporâneo, que muito utilizou dos legados de Michel Foucault para edificar seus pensamentos), em uma conferência realizada no Brasil, em Setembro de 2005, define sua concepção de dispositivo a partir da estratégia de pensamento de Foucault.

Segundo Foucault (1977) apud Agamben (2009) dispositivo consiste em uma rede que a gente estabelece entre um conjunto heterogêneo de coisas, tais como: discursos, instituições, instalações arquitetônicas, decisões regulamentares, leis, medidas administrativas, enunciados científicos, proposições filosóficas, morais, filantrópicas, o dito, o não dito, etc. Consiste em uma estratégia que, em um dado momento, teve a função de responder a alguma urgência, estando sempre inscrito dentro de um jogo de poder.

O mesmo autor, ao procurar pela definição de dispositivo em dicionários franceses, encontrou três significados para o termo que caminham nas seguintes perspectivas: 1) sentido jurídico - a parte da sentença (ou de uma lei) que decide e dispõe; 2) sentido tecnológico maneira onde são dispostas as peças de uma máquina ou de um mecanismo e, por extensão, o mecanismo em si mesmo; 3) sentido militar - conjunto de meios dispostos na conformação de um plano (AGAMBEN, 2009). Se observarmos, todos os significados se encontram, de algum modo, presentes no uso foucaultiano.

Para Agamben (2009), existem duas grandes classes: as substâncias (ou seres viventes) e os dispositivos. Entre elas, uma terceira classe resultante da relação estabelecida entre as substâncias e os dispositivos, que são os sujeitos. Portanto, para ele, dispositivo consiste em 
"qualquer coisa" que tenha a capacidade de capturar $^{26}$, orientar, determinar, interceptar, modelar, controlar e assegurar os gestos, as condutas, as opiniões e os discursos das substâncias.

Dessa maneira, é possível identificar certa distinção entre dispositivo para Foucault e para Agamben. Enquanto Foucault trabalha com a concepção de uma rede estabelecida pelos sujeitos e que se encontra sempre dentro de um processo de relação de poder, Agamben aponta para a existência de qualquer coisa (e não, necessariamente, uma rede) que interfere, de alguma forma, em ações desenvolvidas pelos sujeitos. Ou seja, enquanto, no primeiro, o sujeito é quem pratica a ação na conformação de uma rede, no segundo, é "qualquer coisa" que atravessa, interfere e, consequentemente, exerce a ação sobre o que há de ser desenvolvido pelos sujeitos.

Para Monceau (2015), dispositivo consiste em um agenciamento dinâmico (que se transforma, que está em movimento) de elementos heterogêneos (discurso, escrita, expressões, fotografias, etc.) que se articulam. A partir dessa concepção, é possível identificar maior fluidez entre os elementos que compõem o dispositivo, aproximando-se muito mais de um processo de composição do que de negação (como, por exemplo, na dialética hegeliana, onde uma forma nega a outra). Aqui, esses elementos se entrelaçam, se modificam, se arranjam a partir da necessidade e do contexto.

Estes agenciamentos dinâmicos trazidos por Monceau (2015) podem ser compreendidos ainda, segundo Ceccim (2005b), enquanto quaisquer operadores de sentido (disposições de sentido que operam realidades).

Em uma conferência realizada na EERP/USP, em Abril de 2015, Gilles Monceau relatou acerca de três tipos de dispositivos vinculados à pesquisa: o dispositivo político, o operatório e o analítico.

O dispositivo político corresponde àquilo que o governo utiliza para colocar em prática seus objetivos, atendendo às particularidades regionais e atentando-se para a necessidade de uma readequação desse dispositivo, caso se faça necessária. O dispositivo operatório consiste na maneira efetiva com que os trabalhadores colocarão em prática suas ações, levando em consideração as dimensões política, social, econômica, humana, etc. E o dispositivo analítico corresponde, diretamente, à atividade do pesquisador que busca compreender o que se passa em determinado local e contexto, propondo a produção de conhecimento (MONCEAU, 2015).

Nesse sentido, acreditamos que, por mais simplificada que seja a definição de dispositivo pela PNH e tomando como exemplo o apoio institucional enquanto um dos seus dispositivos, este muito se aproxima da concepção monceauniana por corresponder àquilo que

\footnotetext{
${ }^{26}$ Captura consiste em um aparato que impede, reprime ou destrói as forças instituintes, fazendo permanecer o que se encontra instituído (BAREMBLITT, 2012).
} 
se transforma a partir das necessidades do outro, do território, da equipe e que é composto por uma série de elementos heterogêneos que perpassam, por exemplo, pelas próprias ferramentas adquiridas pelo apoiador em sua trajetória profissional e que se articulam no exercício da função apoio em si.

Ora, trazendo esse contexto para a pesquisa, compreendemos a PNH enquanto um dispositivo político lançado pelo Estado brasileiro (representado pelo Ministério da Saúde). O que consiste em dispositivos para a $\mathrm{PNH}$, corresponde aos dispositivos operatórios a serem utilizados pelos trabalhadores de saúde em prol da tentativa de colocar em prática as diretrizes apontadas pela política. E o exercício realizado por nós, pesquisadores, que escolhemos (e/ou somos escolhidos) para analisar essa política em seus diversos âmbitos (teórico, prático, em associação a outra política, etc.) faz com que lancemos mão de dispositivos analíticos para tal como, por exemplo, as etapas percorridas no desenvolvimento da intervenção socioclínica que aqui propomos.

Ainda no âmbito da pesquisa-intervenção em questão, adotamos a análise de implicação profissional enquanto um dispositivo, por ela corresponder a um processo complexo que se transforma e por ser composta e manifesta por diversos elementos que se articulam, possibilitando a análise das relações que os sujeitos estabelecem com as instituições que os permeiam. Não negamos a ideia de que a análise de implicação profissional possa ser considerada como uma ferramenta, se a compreendermos enquanto, apenas, uma técnica a ser utilizada dentro de um determinado contexto. Contudo, devido a sua complexidade e no âmbito dessa produção, tratá-la-emos enquanto um dispositivo, ultrapassando uma concepção estritamente técnica.

Findadas as definições e contextualizações, daremos seguimento ao texto por meio do aprofundamento em um dos dispositivos apontados pela política: o apoio institucional.

A nomenclatura de apoio institucional foi designada por uma professora chamada Liane Righi, atual Professora Adjunta do Departamento de Saúde da Comunidade da Universidade Federal de Santa Maria (UFSM), em um seminário ocorrido em Setembro de 1998. A partir de então, Gastão Campos, ao propor o método da roda (ou método Paideia) que consiste em um método de apoio à cogestão de coletivos, faz uso dessa nomenclatura por considerar que ela se desassociava da função de analista, supervisor, assessor e consultor utilizadas e desenvolvidas por outras correntes teóricas. Para ele, quem faz a análise não é o apoiador, mas a equipe que ele apoia. O apoiador é responsável por facilitar a abertura de linhas de comunicação que se encontram truncadas, executando um papel de mediador, com o intuito de ampliar o leque de 
possibilidades a serem consideradas pela equipe no desenvolvimento do trabalho em saúde (CAMPOS, 2007; CAMPOS et al, 2017).

Fazemos a consideração de que, para a Análise Institucional, não é nem o apoiador nem a equipe que ele apoia que fazem a análise, mas sim os analisadores que emergem das intervenções realizadas. "O intelectual não é o analisador e sim o analista, com possibilidade de tomar consciência dos efeitos dos analisadores que desencadeiam sua intervenção" (LOURAU, 1993, 2004, p. 80).

Relatando ainda acerca do método Paideia, ele advém de reflexões críticas de textos dos campos da Política, da Análise Institucional e da Educação Continuada. Ora, portanto, nada mais coerente que analisar o apoio institucional a partir da ótica da Análise Institucional que, sinteticamente, analisa "o que os trabalhadores pensam, a alienação, as raivas, o motivo pelo qual se gosta de um usuário, o motivo pelo qual não se gosta, etc.”. O apoio institucional é uma tentativa de fortalecer os trabalhadores; uma maneira de fazer gestão participativa; reconhecer algum problema e oferecer um apoio que não caminha na direção de um paternalismo, mas que seja capaz de levar possibilidades formativas para as equipes (CAMPOS et al, 2017, p. 19).

Ou seja, por meio do apoio institucional, é possível disparar processos de EPS junto às equipes de saúde e à comunidade local. E é, nesse sentido, que o Centro de Desenvolvimento e Qualificação para o SUS (CDQ-SUS), da cidade de Araraquara (CDQ-III), do estado de São Paulo, vem apostando suas fichas no desenvolvimento de seu trabalho.

A título de contextualização, os CDQ-SUS consistem em áreas técnicas do estado de São Paulo criadas em 2006 a partir de um processo de reorganização das 24 Diretorias Regionais de Saúde em 17 Departamentos Regionais de Saúde (DRS). Essas novas áreas técnicas foram designadas a coordenadores responsáveis pela articulação da PNH e da PNEPS em suas respectivas áreas de abrangência regional (BATISTA, GONÇALVES, 2011). O CDQIII vem investindo e organizando estratégias para conseguir implementar essas políticas junto aos 24 municípios que fazem parte da sua região. E, nessa direção, em 2007, pactuou com os gestores municipais a indicação de um profissional de saúde do município que ficasse responsável pela articulação da PNEPS em âmbito local, valendo-se da parceria com o CDQIII enquanto nível estadual de desenvolvimento dessas políticas. A partir dessa experiência, em 2013 lançou mão desse mesmo dispositivo para o desenvolvimento da PNH nos territórios, pactuando com os gestores municipais a indicação de outro profissional (ou do mesmo) para desempenhar a função de apoiador institucional, vinculado às políticas estadual e nacional de humanização. 
A partir de então, o CDQ-III vem desenvolvendo encontros com esses profissionais com a intenção de apoiá-los no desenvolvimento de suas funções nos territórios. Ou seja, o CDQ-III desenvolve EPS e apoio ao trabalho desenvolvido pelos articuladores de EPS e apoiadores de humanização ${ }^{27}$ dos 24 municípios que compõem o DRS de Araraquara. Não consiste, exatamente, em uma lógica de cascata, onde o que é desenvolvido pelo CDQ-III nesses encontros deve ser replicado, multiplicado ou reproduzido pelos articuladores de EPS e apoiadores de humanização em seus municípios. Trata-se de garantir um espaço garantido de apoio às ações desenvolvidas por estes sujeitos em questão em seus respectivos territórios, valendo da EPS para isso.

Apoio para o dicionário português corresponde a tudo que é capaz de amparar, sustentar, proteger, ajudar, informar ou auxiliar de qualquer forma (MICHAELIS, 2017) e é, a partir da própria etimologia da palavra, que afirmaremos que tanto os articuladores de EPS quanto os apoiadores de humanização possuem, enquanto profecia inicial, ou seja, enquanto projeto a ser desenvolvido, o apoio às equipes de saúde em seus processos de trabalho.

Consideramos que as ações desenvolvidas pelo CDQ-III são contra hegemônicas se tomarmos por referência a PEH do estado de São Paulo (SÃO PAULO, 2012) para a fundamentação dessa afirmação. Assumimos a existência de certa sobreimplicação dos autores na realização de possíveis análises acerca do trabalho e das produções que vêm sendo feitas pelo CDQ-III, afinal, compomos, com a coordenadora dessa instância, vários projetos já desenvolvidos e em desenvolvimento. Contudo, a forma com que a PNH e a PNEPS têm sido colocadas em prática pelo CDQ-III é, em seu formato, nitidamente, diferente daquela prevista pela $\mathrm{PEH}$.

A PEH do estado de São Paulo consiste, sinteticamente, em uma política estadual elaborada em 2012 com o objetivo de implementar as ações provenientes da PNH, particularizando para as especificidades existentes no estado de São Paulo. Contudo, consiste em uma política, relativamente, prescritiva, formatada e de difícil articulação com a realidade viva e mutável dos serviços de saúde.

E é baseado nisso que afirmamos a contra hegemonia das ações que vêm sendo planejadas e desenvolvidas pelos DRS. Estes vêm inventando suas maneiras de fazer e colocar em prática as ações que se encontram instituídas em portarias, políticas e decretos nacionais e estaduais. Particularmente, o DRS de Araraquara vem desenvolvendo iniciativas que, sob à ótica da região e da antiga gestão, careciam de reconhecimento, apesar de identificarem

\footnotetext{
${ }^{27}$ Essa consiste na nomenclatura utilizada pelo CDQ-III ao se referir, respectivamente, ao apoiador da PNH (que desenvolve a função de apoiador institucional) e ao articulador da PNEPS nos municípios.
} 
resultados relevantes alcançados por meio do desenvolvimento de alguns projetos (FORTUNA et al., 2016).

O processo de investimento do DRS na formação de trabalhadores (que ocorreu em parceria com outras instâncias como as escolas técnicas do SUS e colegiados) possibilitou uma ampliação na qualificação de gestores e técnicos, caminhando na perspectiva do fortalecimento do trabalho tanto na atenção quanto na gestão em saúde (BATISTA, GONÇALVES, 2011). Em se tratando do DRS de Araraquara, consistiu em iniciativas que também possibilitaram o desenvolvimento do CDQ-III, caminhando muito mais na direção da dialogicidade com os municípios de sua abrangência do que vislumbrando a implantação e o alcance daquilo que se encontrava pré-determinado, tendo a PNH e a PNEPS como principais balizas de suas ações e o dispositivo do apoio institucional enquanto sua grande potência.

Em 2014 a revista Interface Comunicação, Saúde e Educação - que vem sendo apoiada por militantes da reforma sanitária brasileira - lançou uma edição suplementar composta por 24 artigos científicos, 4 produções no espaço aberto e 1 entrevista escrita pela professora Liane Righi e realizada com o professor Gastão Campos referentes ao apoio institucional e às experiências de diversas realidades do país com esse dispositivo. Inclusive, essa revista vem protagonizando as produções científicas com relação a essa temática, correspondendo a cerca de 70\% das produções encontradas ao utilizar o descritor não controlado "Apoio Institucional" na realização de pesquisa científica na Biblioteca Virtual de Saúde.

Portanto, para essa produção, adotamos o apoio enquanto um dispositivo. Compreendendo dispositivo enquanto algo capaz de transformar e ser transformado a partir das diversas necessidades (dos contextos, dos territórios, dos sujeitos, etc.) e o apoio enquanto esse algo que facilita e media o surgimento dos analisadores, com o intuito de colocá-los em análise nos coletivos de trabalhadores de saúde.

Em suma, esse ato finda o processo de contextualização do arcabouço teórico que compõe essa produção. É a partir desse repertório de pautas, estrofes, arranjos e partituras que comporemos a pesquisa-intervenção contemplada nessa produção com o intuito de defendermos a tese de que a análise da implicação profissional consiste em um potente dispositivo para o exercício da EPS. Nesse sentido, adentraremos ao próximo ato que resume o percurso traçado por mim para o delineamento do problema dessa pesquisa. 


\section{DELINEAMENTO DO PROBLEMA DE PESQUISA E JUSTIFICATIVA}

Mediante todo processo de contextualização dessa produção, temos que a formação profissional em saúde ainda possui uma característica conteudista, fragmentada, pautada em uma prática pedagógica de transmissão do conhecimento e orientada pela doença. Ela carece de uma efetiva integração à realidade do trabalho em saúde, necessitando de uma caracterização teórica, conceitual e metodológica direcionadas às necessidades de saúde da população, visando o desenvolvimento do SUS.

Após o processo de formação profissional formal, ou seja, técnico e universitário, ainda é evidente o emprego da PNEPS direcionada a uma lógica que visa apenas a melhoria das condições de trabalho prestados à população e não levando em conta o processo de autonomização e emancipação do trabalhador de saúde, enquanto produtor de sua aprendizagem. Consiste em uma perspectiva de valorização do trabalho morto, ou seja, direcionada a uma lógica de quantificação do trabalho prestado em saúde (quantidade de grupos, reuniões de equipe realizados, por exemplo) em detrimento do trabalho vivo, que consiste no encontro em si, onde o trabalhador está em ação, criando e inventando o fazer em saúde (MERHY, 2007).

Somado a isso e no que concerne ao apoio institucional e à articulação de EPS, a proposição - elaborada pelo CDQ-III - carrega consigo um caráter contra hegemônico no nível das políticas públicas propostas pelo estado de São Paulo. Não dá para não considerarmos as intensas disputas político-partidárias existentes entre o nível Federal - que a partir de 2003 (ano de proposição da PNEPS), passou por 14 anos governados por presidentes vinculados ao Partido dos Trabalhadores (PT) - e o estado de São Paulo - que durante o mesmo período (e até mais que isso) vem sendo governado por políticos aliados ao Partido da Social Democracia Brasileira (PSDB). Portanto, tais atravessamentos político-partidários possibilitam contextualizar ainda mais acerca da contra hegemonia das proposições de trabalho feitas pelo CDQ-III, que pertence ao estado de São Paulo, mas que vem propondo ações que caminham mais na perspectiva das políticas públicas nacionais (PNH e PNEPS).

Assim, esculpindo a proposta inicial, apagando alguns compassos, acrescentando algumas pautas, imergindo no campo de intervenção por meio de outros projetos de pesquisa e remetendo-me ao período em que trabalhei na ESF, cheguei ao ponto central da dificuldade de desenvolver o apoio e ser apoiado, além da necessidade (não só minha) de compor uma caixa de ferramentas para o desenvolvimento do apoio no trabalho em saúde. Não me refiro, diretamente, apenas às técnicas, mas aos dispositivos a serem utilizados no encontro com as 
pessoas. Assim, chegamos à ideia da articulação de dispositivos que pudessem desencadear processos de EPS.

A análise de implicação profissional veio um pouco mais tarde, a partir do aprofundamento teórico (leituras, curso de disciplinas e conversas com amigos brasileiros e franceses), das experiências com o arcabouço da Análise Institucional (projetos de pesquisa desenvolvidos paralelamente ao desenvolvimento dessa tese e a realização do estágio sanduíche na França) e por acreditar tratar-se de um dispositivo potente para o desencadeamento da EPS em ato. Portanto, tal congruência culmina com o delineamento do objeto de estudo que compõe a presente produção.

Portanto, ela emerge das reflexões que suscitaram questionamentos oriundos da minha própria implicação profissional enquanto profissional de saúde e pesquisador, tendo como principais inquietações: Como se dá a implicação profissional dos apoiadores de humanização e dos articuladores de EPS? O que esta implicação profissional tem facilitado e dificultado no exercício da função apoio e na articulação de EPS? E, consecutivamente, colocá-la em análise pode servir como um dispositivo desencadeador de processos de EPS?

Alguns trabalhos têm sido desenvolvidos na perspectiva de analisar a implicação de atores que vêm desenvolvendo a função apoio em suas diferentes perspectivas (PENIDO, 2015; SEVERO et al., 2014; CASTRO, CAMPOS, 2014; MOURA, LUZIO, 2014). Contudo, utilizar a análise de implicação profissional no contexto da PNH e da PNEPS e enquanto um dispositivo desencadeador de processos de EPS, consiste em uma proposição inédita.

A presente obra se harmoniza com as notas musicais da Saúde Coletiva que é compreendida enquanto uma delimitação do campo da saúde, que tem como ponto de partida um conjunto de tendências de ampliação e recomposição do espaço de intervenção, do campo de saber e de prática ocupado dentro das realidades sanitárias brasileiras (DONNANGELO, 1983 apud L'ABBATE, 2013). Ou seja, trata-se de uma nova concepção de pensar e fazer saúde, que leva em consideração, sobretudo, o contexto social no qual os sujeitos se encontram inseridos.

Portanto, esta obra compõe com as produções que vêm sendo desenvolvidas no Brasil e que articulam a Saúde Coletiva à Análise Institucional, contribuindo tanto para o desenvolvimento do conhecimento teórico-prático dentro da Saúde Coletiva quanto com os trabalhos desenvolvidos no âmbito da Análise Institucional, sobretudo, em sua vertente Socioclínica.

Ela também vai ao encontro dos compassos estabelecidos pela saúde pública brasileira - que difere da saúde coletiva por considerar as questões sociais enquanto um objeto ou um 
fato em se tratando das concepções biomédicas e antepondo-se às determinações sociais do processo saúde-doença (MINAYO, 2001) - pois possibilita a problematização e intervenção nas ações desenvolvidas pelos apoiadores de humanização e articuladores de EPS em prol do aperfeiçoamento do trabalho desenvolvido por eles e, consequentemente, promovendo saúde à população em geral. Ou seja, ela atua articulada à várias políticas públicas, sendo a PNH e a PNEPS de caráter direto, procurando potencializá-las por meio da proposição da implicação profissional enquanto um dispositivo que poderá ser utilizado enquanto disparador de processos de EPS.

Além disso, por se tratar de uma pesquisa-intervenção ${ }^{28}$, ou seja, ao mesmo tempo em que a pesquisa foi realizada houve um processo interventivo nas realidades dos sujeitos que a compuseram, ações instituintes foram desencadeadas, tornando a interlocução entre o ato de pesquisar e o de intervir na realidade uma ação estratégica e geradora de transformações. Estas ações poderão influenciar novas formas de realizar o apoio e a articulação de EPS e, consequentemente, possibilitar a melhoria da produção do cuidado em saúde.

Olhando, especificamente, para as pautas musicais que entoam o núcleo ${ }^{29}$ da Enfermagem, esta obra contribui com os processos formativos desenvolvidos por enfermeiros em equipes de saúde e/ou em espaços instituídos de formação profissional, por contribuir diretamente com a EPS e, conforme já explicitado, esta ser uma instância de bastante interesse e ocupação por esta categoria profissional. Além disso, ela possibilita novas articulações de conhecimentos advindos de outras áreas (educação, ciências sociais, etc.) em prol da construção técnico-científica de outros dispositivos (a nível da prática profissional ou dispositivos analíticos se falarmos à nível de pesquisa) direcionados, também, ao trabalho desenvolvido pela enfermagem.

Assim, partimos do fato de que o emprego da PNEPS, enquanto estratégia de formação em serviço e em saúde, tem servido a uma lógica centrada no comando do trabalho morto, havendo uma captura do trabalho vivo, diminuindo a potência do emprego da EPS em ato. Ao mesmo tempo e conforme já explicitado no ato do referencial teórico e metodológico, a análise de implicação corresponde a um dos princípios da Análise Institucional (e da Socioclínica Institucional) e vislumbra analisar as relações que os sujeitos estabelecem com as instituições.

\footnotetext{
${ }^{28}$ Modalidade de pesquisa que será melhor explicitada no $8^{\circ}$ ato desta obra, mais precisamente, no item 8.1 desse ato.

${ }^{29}$ Utilizamos a concepção de núcleo enquanto a identidade de uma área de saber e de uma prática profissional, conforme é pautada por Campos (2000) ao diferir núcleo de campo.
} 
Procurando realizar uma interlocução entre as constatações supracitadas e considerando a análise de implicação profissional enquanto um dispositivo, por produzir um agenciamento dinâmico de elementos heterogêneos que se articulam (MONCEAU, 2015) e que pode ser analítico (quando referimos a sua utilização na composição de pesquisas científicas) e operatório (ao pautarmos a possibilidade de sua utilização, por exemplo, pelos apoiadores e articuladores no fazer apoio e articulação), pressupomos que seu emprego, ou seja, no desenvolvimento de pesquisas-intervenção e no trabalho vivo em saúde, seja capaz de gerar movimentos, reflexões, análises e, consequentemente, desterritorializações, potencializando o desenvolvimento da EPS, segundo o que é pautado pela PNEPS.

Portanto, é a partir desse pressuposto que pretendemos, por meio dessa obra, defender a tese de que a análise de implicação profissional consiste em um dispositivo potente para o desencadeamento de processos de EPS. 


\section{OBJETIVOS GERAL E ESPECÍFICOS}

\subsection{Objetivo Geral}

- Analisar a implicação profissional com os apoiadores de humanização e articuladores de EPS dos municípios do DRS de Araraquara/São Paulo.

\subsection{Objetivos Específicos}

- Identificar a implicação profissional com os apoiadores de humanização e articuladores de EPS dos municípios do DRS de Araraquara/São Paulo.

- Identificar em que a implicação profissional tem facilitado e dificultado no exercício da função apoio pelos apoiadores de humanização e articuladores de EPS nos municípios do DRS de Araraquara/São Paulo. 


\section{PERCURSO METODOLÓGICO}

\subsection{Tipo de Estudo}

Desenvolvemos uma pesquisa socioclínica que consiste em uma pesquisa-intervenção de abordagem qualitativa.

Tal abordagem se deve ao fato de levarmos em conta os níveis mais profundos das relações sociais (MINAYO, 2006), propondo outra relação entre teoria e prática, entre sujeito e objeto, partindo do princípio de que o pesquisador, dentro do campo de intervenção, é capaz de transformar seu objeto, trazendo sua subjetividade como categoria de análise (PEZZATO, PRADO, 2013).

As pesquisas qualitativas enfrentam alguns impasses metodológicos atribuídos ao grande caráter subjetivo de suas investigações. Por isso, essas investigações necessitam estratégias metodológicas e procedimentos investigativos mais abertos e inventivos (PASSOS, KASTRUP, ESCÓSSIA, 2009).

Por isso optamos pelo desenvolvimento de uma pesquisa-intervenção, pois assim praticamos um movimento em que o conhecimento e a ação são coproduzidos, constituindo novas realidades, perguntas e subjetividades (PAULON, ROMAGNOLI, 2010). O projeto político da pesquisa-intervenção consiste no reequacionamento da relação entre o sujeito e o objeto e o redirecionamento da relação da teoria com a prática (PAULON, 2005).

Para Lourau (1993, p. 28) intervenção significa "que o pesquisador é, ao mesmo tempo, técnico e praticante". A estratégia de intervenção utilizada por Lourau, Lapassade e demais socioanalistas para colocarem a Análise Institucional em prática consiste na criação de um dispositivo de análise social coletiva (LOURAU, 1993).

Para L'abbate (2012, p. 197) a Análise Institucional "nasceu da articulação entre intervenção e pesquisa, entre teoria e prática" e para Monceau (2012) a palavra intervenção pode possuir o significado de uma brevidade (como nas intervenções militares ou policial) como é o caso das intervenções socioanalíticas - ou pode significar o fato de "estar entre", adentrando à densidade social de uma situação - como acontece nas intervenções socioclínicas.

Trata-se, portanto, de "estar entre" os sujeitos que participam do dispositivo e a encomenda feita, estar entre a academia e o campo de intervenção, colocando em ato o "vir entre" (vir - subjuntivo do verbo ver), buscando pela "perfeita luminosidade" que seja capaz 
de não escurecer nem cegar os olhos do socioclínico no processo interventivo (L'ABBATE, 2013).

Além disso, vale dizer que a presente pesquisa compõe (ou influenciou na composição) outras modalidades de projetos e pesquisa, que se destinam ao fortalecimento de ações direcionadas ao SUS - Pesquisa para o SUS (PPSUS) $)^{30}$ e InovaSUS $^{31}$ - sendo que, o primeiro, possui um financiamento público específico para o seu desenvolvimento e o segundo corresponde a um prêmio alcançado por parte da equipe de pesquisadores que compuseram essa obra e enquanto desdobramento de um outro projeto de pesquisa, desenvolvido em parceria com o CDQ-III. Por serem pesquisas que acontecem ao mesmo tempo e no mesmo campo de intervenção, são inevitáveis suas aproximações e interferências.

A pesquisa PPSUS tem por objetivo geral analisar as práticas de EPS e apoio institucional dos municípios do DRS de Araraquara. Para isso, pretende passar pela identificação das ações desenvolvidas pelos apoiadores e articuladores; caracterizar o trabalho desenvolvido por eles e apresentar e vivenciar com eles ferramentas e dispositivos possíveis para o desenvolvimento do apoio e da articulação de EPS. Dentre os dispositivos, a análise de implicação profissional consiste em um deles. Portanto, aquilo que se propõe desenvolver em cada uma das pesquisas é diferente e essa, talvez, seja a grande justificativa de as considerarmos como pesquisas que se compõem.

\subsection{Caracterização do Local do Estudo}

O estudo foi desenvolvido no DRS de Araraquara que faz parte da Rede Regional de Atenção à Saúde 13 (RRAS13) e se situa na Região Administrativa de Governo denominada Central. Segundo dados prospectivos do IBGE para o ano de 2015, a região possuiria uma população residente total com cerca de 991.129 habitantes (BRASIL, 2017).

Ela é composta por 24 municípios que estão organizados em 04 regiões de saúde que são: Região de Saúde Central - municípios de Américo Brasiliense, Araraquara, Boa Esperança do Sul, Gavião Peixoto, Motuca, Rincão, Santa Lúcia e Trabijú; Região de Saúde Coração municípios de São Carlos, Descalvado, Porto Ferreira, Ribeirão Bonito, Dourado e Ibaté;

\footnotetext{
${ }^{30}$ Pesquisa financiada em parceria pelo Ministério da Saúde, Conselho Nacional de Desenvolvimento Científico e Tecnológico (CNPq) e Fundação de Amparo à Pesquisa do Estado de São Paulo (FAPESP) com o título "Apoio Institucional e Educação Permanente em Saúde em uma Região de Saúde do Interior de São Paulo: uma pesquisa intervenção" e processo de no 2016/15199-5.

${ }^{31}$ Prêmio intitulado "INOVASUS 2015 - Gestão da Educação na Saúde" de iniciativa do Ministério da Saúde em parceria com a OPAS, cujo projeto premiado possui como título “
} 
Região de Saúde Centro Oeste - municípios de Borborema, Ibitinga, Itápolis, Nova Europa e Tabatinga; Região de Saúde Norte - municípios de Taquaritinga, Cândido Rodrigues, Dobrada, Matão, Santa Ernestina (SÃO PAULO, 2013).

A Região de Saúde Coração é a mais populosa e representa 38,2\% da população desse DRS, além de ser a região com maior densidade demográfica e maior taxa de urbanização. A menos populosa é a Região Centro-Oeste que representa 14,29\% da população total desse DRS, com menor densidade demográfica e menor taxa de urbanização (SÃO PAULO, 2012).

O DRS conta com 09 municípios com população abaixo de 10.000 habitantes, 09 com até 50.000 habitantes, 04 compreendido entre 50.001 e 100.000 habitantes e 02 com mais de 100.000 habitantes. A região conta com um estreitamento da base da pirâmide etária e um alargamento do topo da mesma, apontando para a tendência de envelhecimento da população (SÃO PAULO, 2012).

Com relação ao Índice de Desenvolvimento Humano (IDH), apenas 16,6\% dos municípios possuem índice acima de 0,8 (grau elevado). Os demais possuem índice de grau médio, indicando para o fato de ser uma região com diferenças sociais entre os municípios que a compõe (SÃO PAULO, 2013).

Os municípios de Araraquara e São Carlos consistem nos dois maiores centros econômicos e de governo deste DRS. Araraquara se destaca pela produção predominante de cana de açúcar, suco de laranja, manga, limão, carne de frango e bovina, comportando uma das maiores empresas de sucos cítricos do país. Já São Carlos, consiste em um centro de desenvolvimento de pesquisa, com transferência de tecnologia dura para a iniciativa privada. Possui diversas empresas nesse âmbito e de várias áreas - automação, informática e tecnologia da informação, instrumentação eletrônica, mecânica de precisão, química fina e óptica. No que tange o ramo industrial, o município possui um complexo industrial diversificado nos seguimentos de metalurgia, alimentação, tecido, papel e celulose, borracha, plástico e equipamentos de instrumentação (SÃO PAULO, 2013).

Com relação às questões epidemiológicas, a primeira causa de mortalidade nos municípios deste DRS se dá por doenças do aparelho circulatório, seguido de neoplasias e de doenças do aparelho respiratório. As cinco principais morbidades geradoras de internação são as doenças do aparelho circulatório; doenças do aparelho digestório; doenças do aparelho respiratório; lesões, envenenamento ou alguma outra consequência por causa externa e doenças do aparelho geniturinário (SÃO PAULO, 2016).

Em se tratando da APS e da capacidade instalada de Unidades de Atenção Básica, este DRS apresenta um total de 167 unidades, sendo 43 na região Central, 28 na região Centro- 
Oeste, 29 na região Norte e 67 na Região Coração. Tal configuração, segundo a Portaria GM/MS nº 2488 de 21 de Outubro de 2011 que define as ações e organizações da atenção básica, é suficiente para abranger a população local na realização de ações de promoção, prevenção e recuperação da saúde (SÃO PAULO, 2016). Contudo, os municípios do atual departamento vêm passando por um processo de desconstrução de sua rede de atenção à saúde, sobretudo, no que se refere à APS. Tal fato se deve, especialmente, ao contínuo processo de transição política que esses municípios vêm enfrentando e a articulação direta do modelo de atenção à saúde à gestão político-partidária. Ou seja, consiste em um processo que vivenciamos em todos os níveis federativos (nacional, estadual e municipal). As ações ficam vinculadas ao período político (normalmente, 4 anos) em que o presidente/governador/prefeito se encontra na gestão. A partir de então, em se trocando de partido político nas eleições, a lógica de trabalho parece consistir em um extenso processo inconsequente de desconstrução daquilo que foi edificado durante os 4 anos precedentes, relacionando as ações do período anterior à figura direta do gestor que se encontrava em vigor, desconsiderando os benefícios e malefícios dessas atitudes.

\subsection{Participantes do estudo}

Os participantes que compõem essa produção são os apoiadores de humanização e os articuladores de EPS dos 24 municípios do DRS de Araraquara.

Por compreendermos a pesquisa-intervenção enquanto uma modalidade de pesquisa realizada com as pessoas, consideramo-nos compositores e intérpretes ao mesmo tempo, ou seja, pesquisadores e componentes do estudo. Dessa forma, o autor principal dessa obra e uma equipe de pesquisadores composta pela orientadora dessa produção, 02 professoras do Departamento de Enfermagem (DEnf) da UFSCar, a coordenadora do CDQ-III, 01 mestranda da EERP/USP, 01 doutoranda do DEnf, 03 bolsistas do projeto de Pesquisa para o SUS (PPSUS), 01 enfermeira trabalhadora do município de Ribeirão Preto/SP também fizeram parte das construções das análises aqui expostas, auxiliando durante todo o processo e percurso da pesquisa-intervenção em questão.

Como os apoiadores de humanização e articuladores de EPS são indicados pelos gestores municipais de saúde, portanto, na maioria dos casos, eles estão vinculados, diretamente, a essa pessoa (Secretário de Saúde, Diretor de Saúde, etc.), não existindo, portanto, uma estabilidade no exercício dessa função. Além disso, alguns municípios contam com um grupo de profissionais que desenvolvem o apoio institucional, nomeados para o exercício dessa 
função em seus respectivos territórios. Assim, participaram dessa produção 35 profissionais de saúde que passaram, em algum momento, pela função de apoiador de humanização e/ou articulador de EPS.

Além disso, é possível que o gestor indique um mesmo profissional para o exercício das duas funções. Disponibilizamos a situação de distribuição dos apoiadores e articuladores segundo os respectivos municípios, concernente ao mês de Junho/2017 (Apêndices 1 e 2).

\subsection{Aspectos éticos da pesquisa-intervenção}

Por se tratar de uma pesquisa desenvolvida com seres humanos, o projeto de pesquisaintervenção foi submetido e avaliado pelo Comitê de Ética em Pesquisas com Seres Humanos da EERP/USP, sendo aprovado em 31 de Maio de 2016, segundo parecer de número 1.568.447

e Certificado de Apresentação para Apreciação Ética (CAAE) de número 52679716.8.0000.5393 (Anexo 1).

Para atender aos pré-requisitos de aprovação do projeto, foi necessário o preenchimento de todos os dados e documentos solicitados via Plataforma Brasil. Para tal, necessitamos dos termos de autorização dos gestores de saúde dos 24 municípios, autorizando o desenvolvimento da pesquisa-intervenção com os apoiadores e articuladores. Para isso, contamos com o auxílio da coordenadora do CDQ-III que possibilitou a divulgação desse projeto em reunião da Comissão Intergestores Regional (CIR), facilitando, por meio da cessão do espaço, o contato com os gestores e o recolhimento dos documentos.

Ademais, todos os apoiadores e articuladores foram esclarecidos sobre a pesquisa e deram seu consentimento em participar da mesma, por meio da assinatura do Termo de Consentimento Livre e Esclarecido (Apêndice 3), ficando com uma via assinada por mim.

Com o intuito de preservarmos a confidencialidade dos sujeitos que compuseram essa pesquisa-intervenção, as falas dos apoiadores de humanização e articuladores de EPS nas entrevistas foram identificadas pela sigla AP seguida do número correspondente àquele apoiador e articulador. Já as falas proferidas por estes nos encontros mensais, foram identificadas pela sigla APE seguida do número correspondente ao apoiador e articulador. Somado a isso, tivemos o cuidado de retirar quaisquer indícios que possibilitassem a identificação do apoiador ou articulador durante os momentos de restituição (que serão melhor explicitados no sub-ato de análise dos dados), onde houve o compartilhamento de fragmentos de fala, que exemplificavam determinadas dimensões da implicação profissional dos sujeitos. 
Seguimos essas estratégias no sentido de atribuir aos fragmentos de fala uma conotação genérica, ou seja, que pudesse ter sido expressa por qualquer sujeito e em qualquer espaço da pesquisa, preservando o lugar de onde cada um se expressa. Compreendemos tais encaminhamentos enquanto uma iniciativa de cuidado, inclusive, em se pensando no andamento das análises que se fizeram presentes transversalmente durante toda a pesquisaintervenção.

Somado a isso, os encontros individuais e grupais foram agendados previamente, via contato telefônico com o apoiador e/ou articulador de cada um dos municípios que fizeram parte desta pesquisa-intervenção. Com a finalidade de facilitar esse contato, entre o pesquisador e os apoiadores e articulador, propusemos nos deslocar até os respectivos municípios para a realização das entrevistas individuais e grupais. Fizemos esse investimento tanto no sentido de facilitar a produção dos dados por meio das entrevistas quanto também para proporcionar maior conforto aos participantes das mesmas, afinal, essa proposição garantiria a isenção de qualquer ônus financeiro no custeio de passagens e deslocamentos por parte dos participantes.

Nos municípios, procuramos pactuar e garantir com que os espaços das entrevistas não fossem interrompidos, proporcionando uma experiência que possibilitasse o exercício do aprofundamento nas falas que foram ditas, nas reflexões, análises e diálogos feitos, pois procuramos aproximar a entrevista a um diálogo clínico ao invés de utilizá-la na perspectiva de um repórter ou jornalista na busca de informações (TEDESCO, SADE, CALIMAN, 2013).

Nenhum desconforto por parte dos participantes da pesquisa-intervenção (tanto explicito quanto não verbal) foi manifestado aos pesquisadores na realização das entrevistas e também nos demais espaços utilizados enquanto dispositivos analíticos nessa pesquisaintervenção. Contudo, se tal fato acontecesse, utilizaríamos de estratégias de mediação de conflitos.

\subsection{Dispositivos analíticos utilizados na produção dos dados}

Dizemos que os dados foram produzidos e não coletados, pois o pesquisador compôs a análise de um contexto no qual ele se encontrava implicado, atravessado por diversas instituições e, sobretudo, pelo próprio processo de pesquisar. Assim, a intervenção realizada nos permite dizer que os dados foram co-produzidos pelo pesquisador em conjunto com os demais sujeitos que ali estiveram presentes, nos diferentes contextos e dispositivos analíticos utilizados. Assim, temos que "as mudanças [dos dispositivos], os agenciamentos, por vezes 
uma nova elaboração do quadro fixado previamente, se constrói dentro da temporalidade da pesquisa, trabalhando sobre as tensões e resistências que a atravessam" (BESSAOUDALONSO, 2017, p. 28, tradução livre do autor ${ }^{32}$ ).

Utilizamos, enquanto dispositivos analíticos nesta pesquisa-intervenção: a) entrevista individual e grupal, b) encontros com os apoiadores e articuladores; c) encontros de planejamento e análise e o d) diário de pesquisa.

\subsubsection{Entrevista individual e grupal}

Compreendemos a entrevista enquanto uma possibilidade de imersão na realidade e uma oportunidade de partilhar experiências com os sujeitos. Estando imerso nessa realidade, é possível o estabelecimento de um diálogo situado "entre-vistas": entre o olhar do entrevistado e a do entrevistador, entre o olhar do entrevistado e a realidade que o circunda, entre a visão do entrevistador e a contextualização da fala do entrevistado... enfim, múltiplas maneiras de estar “entre-vistas" e compartilhando experiências contidas em um contexto.

Essa experiência compartilhada atua enquanto um plano, onde os processos que serão investigados acontecem efetivamente, pois a realidade que será investigada não é composta apenas por objetos com contornos precisos e delimitados, mas por processos que desenrolam no cotidiano do trabalho. Dessa forma, cabe também à entrevista, o acompanhamento desses movimentos e dos momentos de mudanças, por meio da fala. Ao mesmo tempo, ela também possibilita uma intervenção sobre essa realidade, por meio da catalisação de instantes de passagem que acontecem durante o percurso de sua realização. Além disso, ela fornece a possibilidade de gerar efeitos no plano coletivo que alí se encontra, ou seja, na díade pesquisador-pesquisado, afinal, ambos revisitam e compartilham experiências por meio do diálogo (TEDESCO, SADE, CALIMAN, 2013).

A entrevista não visa objetos fixos, ou seja, não coleta informação relativa a
referentes ligados a mundos pré-existentes. Não buscamos o conteúdo da
experiência (seja ela anterior ou subjacente ao momento da entrevista),
entendido como um conjunto de dados que a palavra traduziria na organização
transparente do relato. A entrevista não se dirige exclusivamente à
representação que os fazem de objetos ou estados de coisa, os conteúdos das
experiências de cada um, frequentemente privilegiados nas pesquisas em geral
(TEDESCO, SADE, CALIMAN, 2013, p. 301).

32 "Les changements, les agencements, parfois une nouvelle élaboration du cadre fixé préalablement, se construisent dans la temporalité de la recherce en travaillant sur les tensions et résistances qui la traversent" (BEASSAOUD-ALONSO, 2017, p. 28). 
As entrevistas foram iniciadas em Agosto de 2016. Elas foram agendadas previamente e desenvolvidas nos respectivos municípios de cada um dos apoiadores e articuladores (com exceção de uma apoiadora e articuladora que pediu para que a entrevista ocorresse em Araraquara, pois aproveitaríamos o ensejo de sua ida a esse município para outra atividade). Os agendamentos foram feitos, ora por contato telefônico direto com os apoiadores e articuladores (a partir de uma listagem disponibilizada pela coordenadora do CDQ-III), ora via contato telefônico com a Secretaria ou Departamento de Saúde do município, ora via aplicativo WhatsApp. Este último, em especial, foi o recurso mais utilizado durante todo o percurso de agendamento e de troca de informações (endereços, referências para se chegar até o local de realização da entrevista, etc.) entre o entrevistador e os/as entrevistados/as.

Consistiram em 19 entrevistas que foram gravadas e transcritas na íntegra. Nos municípios onde os apoiadores de humanização e os articuladores de EPS eram pessoas diferentes, foram realizadas entrevistas grupais $^{33}$ compostas por ambos sujeitos e o entrevistador. Além disso, 01 dos municípios apresenta um grupo de apoiadores institucionais formado há mais de 5 anos, composto por uma equipe multiprofissional que desenvolve o apoio às unidades de saúde locais. Nesse município, também realizamos uma entrevista grupal com esse grupo de apoiadores, além da entrevista individual com a apoiadora de humanização e articuladora de EPS.

Portanto, dentre as 19 entrevistas realizadas em 18 municípios, 12 foram grupais e 07 individuais. 06 municípios se encontravam sem a figura do apoiador e do articulador no momento em que as entrevistas foram realizadas, consistindo na principal justificativa para não serem incluídos nesse dispositivo analítico. Além disso, bastava ser apoiador de humanização ou articulador de EPS para atender ao critério de inclusão nessa pesquisa, não levando em consideração o tempo de exercício na(s) função(ões) enquanto um critério a ser atendido. Isso está diretamente relacionado aos objetivos pretendidos por esta produção, de analisar a implicação profissional, partindo do pressuposto de que todos os sujeitos se encontram implicados, independente do tempo no exercício da função apoio e/ou na articulação de EPS.

Foram entrevistados 11 apoiadores de humanização, 11 articuladores de EPS, 07 sujeitos que eram apoiadores e articuladores em seus municípios e 01 grupo de apoiadores institucionais compostos por 06 profissionais (incluindo a apoiadora de humanização e articuladora de EPS), correspondendo a um total de 35 sujeitos entrevistados. O tempo de cada

\footnotetext{
33 "Seja numa entrevista grupal ou individual, o manejo guia em direção à experiência em seu plano coletivo de forças, para ensejar a criação de novas perspectivas" (TEDESCO, SADE, CALIMAN, 2013, p. 311).
} 
entrevista dependeu se a mesma foi individual ou grupal. As grupais giraram em torno de 6090 minutos e as individuais em torno de 30-40 minutos.

Algumas questões auxiliaram no movimento das entrevistas. A ideia não foi de que os entrevistados respondessem puramente às questões pré-estabelecidas. Portanto, foi necessária uma movimentação e coletivização das questões investigadas, no sentido de envolver a criação de novas ideias, sentidos e que traçasse novas linhas de conversa. Concordamos que vale construir questões, avivando-as com outras vozes e fazendo-as proliferar e diferirem de si (TEDESCO, SADE, CALIMAN, 2013). Assim, as questões foram compartilhadas com alguns pesquisadores e também com a coordenadora do CDQ-III no sentido de criar novas ideias e sentidos, sendo adotadas as seguintes questões enquanto iluminadoras do processo de condução das entrevistas: 1) Fale-me o que você tem desenvolvido enquanto apoiador de humanização e articulador de EPS em seu município; 2) Fale-me quais as facilidades e dificuldades para o desenvolvimento do apoio em seu município; 3) Fale-me o que você entende por apoio.

\subsubsection{Encontros com os apoiadores e articuladores}

Uma das grandes dificuldades vivenciadas pelos profissionais de saúde consiste na organização de encontros para o desenvolvimento da EPS, justificado, muitas vezes, por suas intensas rotinas de trabalho (PERES, SILVA, BARBA, 2016). Foi, exatamente, nessa perspectiva que o CDQ-III criou e vem garantindo, a partir de 2007, a realização de encontros com os apoiadores de humanização e articuladores de EPS. A ideia é possibilitar momentos destinados à EPS com esses profissionais, visando a criação de estratégias e respostas possíveis às questões que envolvem seus trabalhos em seus respectivos territórios, refletindo e analisando suas práticas profissionais.

A prática profissional corresponde ao

Conjunto de atualizações das implicações profissionais de um sujeito, principalmente das falas, dos escritos e dos atos [...] ela é, mais amplamente, toda prática social, incluindo maneiras de se relacionar com os outros membros da profissão (e, ou, com outras instituições envolvidas na profissão), de pensar essas relações e de lhes atribuir sentidos e valores (MONCEAU, 2012, p. 19, tradução livre do autor ${ }^{34}$ ).

\footnotetext{
34 "Ensemble des actualisations de l'implication professionnelle d'um sujet, principalement des paroles, des écrits et des actes. La pratique professionnelle, et plus largement toute pratique sociale, inclut donc les manières d'être relié aux autres membres de la profession (et/ou autres institutions concernées par la profession), de penser celleci, de lui atribuer du sens et de la valeur" (MONCEAU, 2012, p. 19).
} 
E a análise das práticas profissionais corresponde a uma das modalidades da Socioclínica e "supõe o manejo de técnicas operatórias experimentais sobre diferentes domínios" (MONCEAU, 2012, p. 18, tradução livre do autor ${ }^{35}$ ).

Portanto, temos que a minha aproximação junto ao campo de intervenção se deu desde a minha inserção no PPGESP, em 2014, por meio da participação nesses encontros mensais com os apoiadores e articuladores e também por meio do desenvolvimento de outro projeto de pesquisa, que envolveu a Região de Saúde Coração do DRS de Araraquara $^{36}$. Consequentemente, parte dos apoiadores e articuladores que compuseram essa pesquisa já se faziam presentes naquele momento. Nesse sentido, optamos por realizar um recorte temporal das minhas participações nesses encontros com os apoiadores e articuladores com o intuito de compormos a produção que aqui se encontra.

Fizemos este recorte tomando como início o mês de aprovação do projeto de doutorado pelo Comitê de Ética em Pesquisa com Seres Humanos da EERP/USP e como final o mês que antecede a data limite para o depósito da tese no PPGEPS contabilizando, portanto, 10 encontros com os apoiadores e articuladores. Os movimentos, falas, provocações, apreensões e análises realizadas nesses encontros constaram enquanto anotações redigidas por mim em meu diário de pesquisa, que será melhor explicitado mais adiante. As possibilidades de reflexão e análise das práticas profissionais foram possíveis de serem realizadas por meio da valorização dos conhecimentos existentes e manifestados nos diferentes espaços desta pesquisaintervenção, dos saberes disponíveis no entorno dos mesmos e do trabalho enquanto uma rede de apoio que visa à participação de todos os envolvidos no processo em si, indo ao encontro do que se espera para o desenvolvimento da EPS.

Foi ainda nesses espaços que realizamos os momentos de restituição que, enquanto um dos princípios da Socioclínica Institucional, consiste em "produzir oportunidades para aprofundar ou para questionar análises, ou mesmo reconsiderar a orientação do próprio dispositivo de trabalho" (MONCEAU, 2013, p. 100). Portanto, a restituição foi acontecendo a cada encontro com os apoiadores e articuladores. Contudo, foram organizados 02 encontros específicos para realizarmos momentos de restituições daquilo que foi produzido nas entrevistas individuais e grupais, possibilitando um maior direcionamento ao processo de análise coletiva desses dados.

\footnotetext{
35 “[L'analyse institutionnelle des pratiques sociales] suppose le maniement de techniques opératoires expérimentées sur différents terrains" (MONCEAU, 2012, p. 18).

${ }^{36}$ Projeto na modalidade de Pesquisa para o SUS (PPSUS), processo no 2014/50037-0, intitulado "Cogestão, Apoio Institucional e Acolhimento na Atenção Básica: uma pesquisa-intervenção".
} 


\subsubsection{Encontros de planejamento e análise}

Os encontros com os apoiadores e articuladores eram precedidos de um encontro de planejamento, seguidos de um encontro de análise. Esses espaços também eram permeáveis à participação dos apoiadores e dos articuladores, sendo que os mesmos sempre foram convidados pela equipe de pesquisadores a compô-los. Este dispositivo foi colocado em prática a partir de Março de 2017 e os encontros não foram transcritos, mas redigidos no meu diário de pesquisa, correspondendo a 07 encontros no total.

Os encontros de planejamento duraram, em média, 3 horas e tinham a intenção, como o próprio nome diz, de conseguirmos um espaço - enquanto grupo de pesquisadores e com a presença de apoiadores e articuladores - para planejarmos os disparadores que seriam colocados em prática nos encontros mensais com os apoiadores e articuladores. Somado a isso, potencializamos esse espaço com a realização de sessões de aperfeiçoamento teórico acerca de temáticas vinculadas ao referencial teórico-metodológico da Análise Institucional e também acerca das ferramentas e dispositivos que foram elencados pelos apoiadores e articuladores e que colocados em prática nos encontros com eles. Acordamos com a ideia de que

Ter o dispositivo, pensá-lo dentro do tempo para fazê-lo com os sujeitos, contribui com a pesquisa, mas também com a equipe de pesquisadores, em particular quando esta associa os pesquisadores e os trabalhadores no levantamento de questões sobre o dispositivo (BESSAOUD-ALONSO, 2017, p. 28, tradução livre do autor ${ }^{37}$ ).

Os encontros de análise, ocorridos logo após e ainda no calor dos encontros com os apoiadores e articuladores e no mesmo formato dos encontros de planejamento no que diz respeito a sua composição e tempo médio de duração, serviram como espaços de análise tanto dos encontros realizados com os apoiadores e articuladores quanto das implicações dos pesquisadores que alí se encontravam. Foram, principalmente, nesses momentos que eu pude realizar grande parte das análises das minhas implicações com as instituições que me atravessavam e interferiram no fazer, pensar e colocar-me dentro do coletivo de trabalho. Partimos da premissa de que "a implicação, por sua vez, deve ser analisada individualmente e coletivamente, o que supõe atividade intensa e, muitas vezes, penosa" (LOURAU, 2004a, p. 191).

\footnotetext{
37 "Tenir le dispositif, le penser dans le temps pour faire avec les sujets contribuant à la recherche mais aussi avec l'équipe de recherche, en particulier quand celle-ci associe des chercheurs et des praticiens, soulèvent des questions au fil du dispositif” (BESSAOUD-ALONSO, 2017, p. 28).
} 
Portanto, era neste momento que sentia ser possível me atentar um pouco mais para as minhas falas, para as instituições que me atravessavam naquele momento e no momento precedente em que me encontrava com o grupo dos apoiadores e articuladores de EPS. Ao mesmo tempo, fiz o movimento de redigir minhas análises e as análises feitas pelos demais membros do grupo em questão no diário de pesquisa.

\subsubsection{Diário de pesquisa}

A intensidade dos encontros e dos momentos e o que pôde ser apreendido por mim, foi redigido no meu diário de pesquisa. O diário, na perspectiva da Análise Institucional, é entendido como:

Uma ferramenta de intervenção que tem o potencial de produzir um movimento de reflexão da própria prática, na medida em que o ato da escrita do vivido, no âmbito individual ou no coletivo, é o momento de reflexão sobre e com o vivido, revelando o não dito e pressupondo a não neutralidade do pesquisador no processo de pesquisar (PEZZATO, L'ABBATE, 2011, p. 1303).

Existem vários tipos de diários empregados como ferramentas na Análise Institucional. O diário de pesquisa é um deles e ele "reconstitui a história subjetiva do pesquisador. Mostra, entre outras coisas, a contradição entre a temporalidade da produção pessoal e a institucional, ou burocrática" (LOURAU, 1993, p. 78). Ele consiste em "uma narrativa do pesquisador em seu contexto histórico-social, um pesquisador implicado com e na pesquisa e que reflete sobre e com sua atividade de diarista" (LOURAU, 2004 apud JESUS, PEZZATO, ABRAHÃO, 2013), além de permitir o conhecimento do cotidiano da prática da pesquisa, retratando o "como foi feita" e não o "como fazer" (LOURAU, 1993).

O diário de pesquisa começou a ser produzido desde antes da minha inserção no PPGESP e, exatamente, a partir da minha expectativa de ingressar nesse Programa. Vale a pena apontar que o processo de escrita no diário de pesquisa também foi modificando com o passar do tempo. Parece que fui me permitindo escrever mais e do meu jeito sem, necessariamente, me preocupar com aquilo que iria compor essa produção e o que ficaria de fora dela.

Dos espaços formais aos informais, dos encontros com os sujeitos dessa pesquisa aos encontros nos cafés e nas mesas de bar. As reflexões e análises com amigos e companheiros/as de trajetória fizeram parte da composição deste diário de pesquisa. Parti do pressuposto de que foram nesses "aspectos marginais" da pesquisa - nos cafés ou tomando um copo de cerveja ou 
uma taça de vinho - que compus vários instantes disparadores para uma efetiva análise das minhas implicações enquanto pesquisador (LOURAU, 1993).

Portanto, desenvolvi meu diário de pesquisa, abordando toda a minha trajetória diante do ato de pesquisar, das aproximações e distanciamentos com o referencial teórico, das dificuldades e avanços alcançados na trajetória percorrida, enquanto um sujeito implicado com a pesquisa, com o apoio, com a articulação de EPS e com a Universidade.

\subsection{Análise dos Dados}

Retomando o que se encontra no $2^{\circ}$ ato, a Socioclínica Institucional constitui na base teórica e metodológica que fundamenta essa produção. Ela, a partir de seus princípios, compôs o arcabouço para análise dos dados que foram produzidos nas entrevistas e no processo de análise das práticas profissionais com os apoiadores e articuladores, ou seja, a análise dos dados se deu durante todo o processo de investigação.

O preparo do material das transcrições para análise foi feito segundo as proposições feitas por Paillé e Mucchielli (2012). Estes destacam três momentos nesse processo: 1) o trabalho de transcrição em si, onde passamos uma cena ou um testemunho para a forma escrita; 2) o trabalho de transposição que consiste no momento em que palavras e gestos são reconsiderados e restituídos por meio das palavras do pesquisador e; 3) o trabalho de reconstituição que consiste na narrativa argumentada em torno das principais categorias de análise, avenidas e pistas de compreensão.

Portanto, as transcrições das entrevistas passaram por um processo de releitura em consonância com a escuta das gravações, com o intuito de realizarmos possíveis correções e retiradas de fragmentos, termos e nomes que pudessem identificar os sujeitos, além de já irmos nos aproximando das falas nelas contidas. O momento da transposição foi realizado posteriormente, onde as transcrições foram relidas diversas vezes, acrescentando considerações anotadas em meu diário de pesquisa e que tinham relação com as leituras não-verbais e expressões identificadas no momento das falas (pausas, momentos de tensão, descontração, risos, ironia, etc.). E, finalmente, realizamos o momento de reconstituição, buscando analisar o material transcrito e transposto segundo os princípios da Socioclínica Institucional, procurando por fragmentos, contextos, expressões que indicassem, de alguma forma, as implicações profissionais dos sujeitos (nas dimensões libidinal, organizacional e ideológica, inclusive dos pesquisadores) e os analisadores, atravessamentos e interferências institucionais no processo da pesquisa. 
A partir da análise do material transcrito, partimos para os momentos de restituição. $\mathrm{Na}$ restituição "supõe que se deva, e se possa falar de algumas coisas que, em geral, são deixadas à sombra. Essas coisas seriam as comumente silenciadas, faladas apenas em corredores, cafés" (LOURAU, 1993, p. 51). Assim, conforme já exposto, organizamos três momentos de restituição dos dados concernentes às entrevistas: um em Outubro de 2016 - onde parte das entrevistas foi restituída e analisada coletivamente - outros em Agosto e Setembro de 2017, onde foi restituído o conteúdo das entrevistas feitas e também algumas análises das implicações profissionais.

Portanto, como os dados produzidos foram restituídos e analisados coletivamente, podemos dizer que não fugimos às interferências existentes diante da diferença entre as entrevistas individuais e grupais. Sim, compreendemos que as entrevistas realizadas com mais de uma pessoa são diferentes no sentido de que, quanto mais pessoas se encontram refletindo acerca de determinado objeto, mais rico e diverso pode ser o processo de análise. Contudo, a mescla dos diversos dispositivos analíticos colocados em prática nesta pesquisa-intervenção possibilitaram também uma maior diversidade de dados e, consequentemente, uma ampliação dos caminhos da análise coletiva realizada nos momentos de restituição.

O processo de restituição possibilitou um aprofundamento analítico daquilo que já havia sido produzido e das minhas implicações enquanto pesquisador. Tais considerações foram redigidas no diário de campo para, posteriormente, serem retomadas em processo de análise, buscando por uma auto-análise das minhas próprias implicações com essa produção. Tal fato corresponde ao ato que segue. 


\section{ANÁLISE DE ALGUMAS IMPLICAÇÕES DO PESQUISADOR}

Compreendemos a interlocução existente entre as dimensões que compõem as implicações dos sujeitos. É, inclusive, por isso que tentaremos expor, nesses próximos atos, algumas dimensões que se fizeram mais visíveis na relação pesquisador-instituições. Contudo, no sentido de desvencilharmos de uma postura equivocada com relação à análise de implicação proposta pelo referencial teórico e metodológico da Socioclínica Institucional, assumimos a grande dificuldade em fazermos uma fragmentação das implicações a partir de suas dimensões ideológica, libidinal e organizacional. Afinal, a ideia, segundo Lourau (2003), não consiste em identificarmos a implicação, mas colocá-la em análise.

Contudo, com o intuito de atingir os objetivos propostos pela pesquisa-intervenção em questão, vimos a necessidade de fragmentarmos as dimensões que compõem as implicações, caminhando muito na perspectiva de atender à encomenda de tornar mais acessível e compreensível ao(s) leitor(es) dessa obra, sobretudo, aos profissionais de saúde, a utilização da análise de implicação enquanto um dispositivo desencadeador de EPS. Portanto, assumimos aqui esse "equívoco", ressaltando nossa compreensão do embricamento existente entre as dimensões que compõem as implicações.

Não foi ao acaso que também decidimos iniciar o ato dos resultados pela exposição das minhas implicações. Isso se deve à necessidade de contextualizarmos com quem os sujeitos dessa pesquisa relataram seus cotidianos, anseios, desejos, o apoio e a articulação que fazem (ou não) em suas realidades. Identificar a análise da implicação desse interlocutor poderá gerar pistas para o aparecimento (ou não) de determinados nós críticos no trabalho do apoiador e articulador de EPS. Além disso, compactuamos com Lourau (1993) de que a análise da implicação do pesquisador deve estar no âmago da pesquisa, levando à produção de um novo tipo de intelectual.

Iniciamos relatando que o delineamento da pesquisa-intervenção que compõe essa produção perpassou por diversos momentos. Ateremo-nos aqui, aos compassos que foram sendo construídos um pouco antes e durante o percurso de doutoramento no PPGESP.

Em 2014, iniciei o doutorado na EERP/USP. Naquele momento, acreditei que, com a inserção na pós-graduação, conseguiria também uma bolsa de estudos, podendo desenvolver os trabalhos do doutorado com tranquilidade e exclusividade. Mas essa canção não foi tão harmônica e melodiosa conforme minhas expectativas. Foi necessário trabalhar durante os dois primeiros anos do doutorado ao mesmo tempo em que desenvolvi algumas atribuições 
“esperadas" de um doutorando (em uma organização que é referência mundial na formação de enfermeiros, mestres e doutores): curso de disciplinas e alcance de créditos, delineamento do problema e elaboração do projeto de pesquisa com o intuito de conseguir financiamento de alguma agência de fomento, melhoria do currículo por meio da inserção em projetos de pesquisa e aumento da produção científica, além da qualificação do projeto de pesquisa.

Tendo o dinheiro enquanto um analisador bastante sensível (LOURAU, 1997) e analisando a minha implicação nessa direção, posso dizer que o anseio por conseguir me dedicar, exclusivamente, ao doutorado fez com que eu me articulasse e movimentasse em prol da busca pelo alcance de determinados parâmetros tidos enquanto insuficientes para a obtenção de uma bolsa de estudos e de um financiamento próprio para o desenvolvimento da minha pesquisa. Portanto, ao mesmo tempo em que eu fui me aproximando do referencial teórico e metodológico da Análise Institucional, com o intuito de tecer um bom projeto de pesquisa e que fosse financiável, fui também aperfeiçoando meu currículo por meio do desenvolvimento de outros projetos de pesquisa (PPSUS e InovaSUS), que, inclusive, me possibilitaram a inserção no meu campo de intervenção e dedicação à produção científica. Somado a isso, conforme já exposto nas notas preliminares, desenvolvia algumas atividades profissionais em concomitância, afinal, a autonomia financeira se fazia necessária ao percurso de doutoramento.

Muitas coisas se passaram. Fui aprovado no doutorado, terminei um curso de
facilitador em metodologias ativas pelo IEP/SL e dias atrás fui convidado pela
mesma organização para ser facilitador em um curso de Aprimoramento em
Qualidade e Segurança do Paciente. Aceitei, claro, afinal, a situação que eu
estou não é nenhum pouco confortável (sem bolsa e dependendo de ajuda
financeira para sobreviver) (diário de pesquisa, 09/06/2014).

Portanto, logo se percebe que o projeto de pesquisa que precede essa pesquisaintervenção carrega consigo algumas encomendas em sua elaboração, sendo também a necessidade de consistir em um projeto de pesquisa financiável por alguma agência de fomento. Compreendo "projeto de pesquisa financiável" enquanto aquele que tenha uma amplitude e um certo impacto na realidade dos serviços de saúde, consequentemente, na vida da população em geral. E foi pensando dessa forma, que elaborei esse projeto de pesquisa-intervenção, abrangendo 24 municípios e diversos sujeitos.

A tarefa de ter que trabalhar enquanto se pretende produzir intelectualmente é, por vezes, algo insano. Contudo, acreditar que o trabalho que estava sendo realizado era coerente com as dimensões ideológicas da minha implicação profissional me sustentava, de alguma forma, a seguir adiante, sem tanto sofrimento. 
Em se pensando, especificamente, no campo de análise, o analisador dinheiro interferiu competindo com a minha dedicação ao aperfeiçoamento e aproximação do referencial teórico e metodológico aqui utilizado, afinal, não era fácil dedicar-me ao mesmo tempo no aprofundamento teórico (que exige tempo e concentração para tal) e no desenvolvimento de atividades paralelas que me proporcionavam o dinheiro necessário para viver bem. Isso também foi vivenciado posteriormente, no momento da escrita da tese, onde já me encontrava trabalhando enquanto docente substituto na UFSCar e também enquanto enfermeiro da ESF no município de São Carlos.

O analisador dinheiro reflete também muito da minha dimensão libidinal na implicação familiar. $\mathrm{O}$ trabalho associado à figura materna interfere, cotidianamente, na minha implicação com a instituição trabalho. Ou seja, é necessário estar sempre trabalhando, produzindo e conquistando dinheiro para o próprio sustento. Qualquer possibilidade que desvie dessa representação e que, consequentemente, se aproxime um pouco mais da representação do nãotrabalho, a qual faço relação direta à figura paterna, desencadeiam movimentos de negação e repressão, inconscientes e expressos por mim.

Afinal, a subjetividade humana sempre foi um assunto que admirei e quis estudar/compreender. Acho que muito disso vem de mim, de tentar me entender como gente, como pessoa, como homossexual. De tentar entender meu arranjo familiar, sobretudo, minha relação um tanto quanto ruim/distante do meu pai e um tanto quanto próxima da minha mãe. E por falar em mãe, acho que eu preciso trabalhar (diário de pesquisa, 21/07/2013).

Por aí, é possível compreender a dificuldade em iniciar o doutorado sem bolsa e, naquele momento inicial, também sem emprego. Apesar de acreditar na trajetória que estava traçando e de trilhar percursos que me levariam aos meus objetivos de vida (e de outros), não foi nada fácil aceitar e compactuar com o auxílio financeiro despendido pelo meu companheiro no início do doutorado.

Deixei uma pós-graduação latu senso para me dedicar única e exclusivamente a esse projeto. Projeto de vida, inclusive, pois não envolve apenas o meu querer pesquisar e me tornar docente algum dia, mas também os anseios e necessidades de estar no mundo e vivendo uma vida a dois - eu e meu companheiro. Na verdade, em alguns momentos, questionei-me o quanto esse projeto era meu, e só meu, e o quanto esse projeto fazia parte mais dos anseios e necessidades dele. É, de fato, esses sentimentos mesclam, vão e voltam, mas sinto - lá no fundo - que é uma trajetória que percorreria inevitavelmente, ou seja, é um caminho que eu iria trilhar algum dia (diário de pesquisa, 23/07/2013). 
Em se tratando da relação do analisador dinheiro e do campo de intervenção, esse processo foi também algo de extrema relevância, pois foi necessário um deslocamento até os municípios que compõem do DRS de Araraquara para realização das entrevistas com os apoiadores e articuladores. Somado a isso, ligações para pactuação e agendamento das entrevistas compuseram os gastos de custeio a essa pesquisa-intervenção. Tudo isso tem um custo e esse custo, muitas vezes, foi despendido por meio de recursos próprios ou pelo auxílio do meu companheiro, que também acreditou na potência do trabalho em questão e que comporia a minha tese.

Aproveito o ensejo para adentrar à análise da minha implicação com a instituição familiar. Avalio estabelecer um movimento de pouca resistência aos parâmetros já instituídos. Por exemplo, não considero o fato de ser homossexual e viver junto com meu parceiro, como sendo um grande enfrentamento ou uma resistência à instituição familiar, afinal, reproduzimos e conformamos uma família pautada em pactos e moldes ocidentais e tradicionais (monogâmica, residindo na mesma casa, compartilhando do mesmo quarto, etc.).

Resistência seria se escapássemos a essa captura, um tanto heteronormativa, que reproduzimos dentro de um relacionamento homoafetivo. Penso ainda que poderíamos ir um pouco além, lutando e militando mais pelos direitos dos gays, das lésbicas, bissexuais, transexuais, etc. Ao mesmo tempo, percorrer por estes trajetos de militância sem imergir por completo, me possibilita transduzir na minha relação com este "objeto". Trata-se, talvez, de tentar não imergir completamente (participando de movimentos, por exemplo) e não emergir dessa causa - algo inevitável, pois a componho - procurando encontrar um intermédio, uma ótica que me possibilite refletir e desenvolver certa análise crítica acerca dessa instituição.

Portanto, o meu não engajamento nos movimentos e militâncias refletem um tanto da minha implicação com a instituição (e que não deixa de ser política também). Faço a mesma relação com a minha implicação com o sistema público de saúde. Tenho minhas dimensões ideológicas ao acreditar nos princípios e diretrizes do SUS e de suas políticas, mas procuro, da mesma forma, um equilíbrio (intermédio ótico), capaz de não me cegar e de me possibilitar novas análises e reflexões acerca dessa instituição, da forma como os sujeitos se implicam nela e com ela e, também, da forma como me encontro implicado. Portanto, "estar implicado (realizar ou aceitar a análise de minhas próprias implicações) é, ao fim do cabo, admitir que sou objetivado por aquilo que pretendo objetivar" (LOURAU, 2004, p. 48).

Tomado por minha sobreimplicação, por não considerar uma família formada por dois homens enquanto um processo de resistência em si aos padrões sociais da instituição familiar, redigi os parágrafos anteriores e optamos por deixá-los aqui registrados, considerando-os 
enquanto um exemplo de sobreimplicação e que, na redação deste atual parágrafo, deixa de configurar uma sobreimplicação, tornando-se a análise da implicação em si, desobstruindo a cegueira que impedia a realização daquela análise.

Consistiu em um exemplo objetivo das transformações que se produzem à medida que o trabalho avança, afinal, os parágrafos aqui redigidos não o foram construídos linearmente e cronologicamente, mas por meio de idas e vindas, leituras e releituras, sendo que cada distanciamento e reaproximação configuraram em um momento de reanálise daquilo que aqui se encontrava expresso. $\mathrm{O}$ autor, certamente, não era o mesmo ao retornar à leitura dos parágrafos acima e, por isso, redigiu o parágrafo precedente, ao identificar sua sobreimplicação no momento de análise e da escrita. Além disso, a tese e as obras acadêmicas parecem funcionar dessa forma, há sempre uma vírgula a ser trocada de lugar, uma melhoria na construção da frase precedente, com o intuito de se fazer entender e de possibilitar uma melhor apreensão daquilo que foi colocado em prática, em ato.

Com relação à análise da minha implicação com a pesquisa, temos que quando falamos em implicação em pesquisa, "nos referimos ao conjunto de condições da pesquisa. Condições inclusive materiais, onde o dinheiro tem uma participação tanto econômica quanto libidinal" (LOURAU, 1993, p. 16). Nessa trajetória, fui tecendo rascunhos, entoando algumas notas dissonantes e percorrendo pautas trêmulas e incertas do processo de delimitação do objeto de estudo, da tese a ser defendida, das expectativas, dos anseios, desejos e afetos. Minha inserção em outros projetos de pesquisa aconteceu como se fosse algo natural, que eu precisaria percorrer enquanto doutorando (e não é que teria mesmo?). A dimensão libidinal da minha implicação com a tese era extrema a ponto de negar, por vários momentos, os "devaneios" e "erros de percursos" pelos "terrenos desconhecidos". Interpretava tudo isso como uma "fuga do foco". Esses terrenos compuseram os aprendizados e conquistas alcançados por meio da inserção nos projetos de pesquisa junto a minha orientadora (PPSUS e InovaSUS) e outras muitas experiências alçadas e jamais imaginadas previamente.

Preciso de foco. As leituras já não entram mais em minha mente (diário de pesquisa, 04/06/2014).

(...) e outra, mantenho minhas atividades focando apenas nos apoiadores de humanização? Essa era a ideia inicial, mas agora os articuladores de EPS se encontram juntos. Sim, compreendo como sendo um único trabalho, trabalhar com ambos, mas e o foco da minha tese? (diário de pesquisa, 12/09/2016).

Tenho estado mais atento ao fato do meu projeto de doutorado. Preciso me dedicar mais ao objetivo maior de estar aqui (França). Creio que revisitarei minha qualificação e iniciarei a partir dela. Está aí, uma boa pedida. Revisitar esse momento antes de falar com o Gilles também seria bacana no sentido de 
ir mais focado para a nossa conversa. Isso mesmo! (diário de pesquisa, 27/09/2015).

A dimensão organizacional da minha implicação com a pesquisa e com os projetos PPSUS e InovaSUS desenvolvidos conjuntamente à tese foi um processo que dificultou, por alguns momentos, que eu conseguisse identificar a minha tese no meio de tantas ações, objetivos e projetos diferentes. Por mais que concordamos com o fato de que a minha tese é parte e compõe esses projetos, por vezes me senti um pouco perdido, sem entender muito bem o que era dela, o que era do PPSUS e o que era do InovaSUS. É impossível não assumir as interferências e atravessamentos que um projeto exerceu sobre o outro e vice-versa. Contudo, reflito sobre a possibilidade de consistir em um processo cartesiano e endurecido de fazer pesquisa - modelo arraigado a nossos processos de formação enquanto pesquisadores. Um movimento fragmentado, onde cada pesquisa é uma pesquisa e que não, necessariamente, se compõem, se articulam e justapõem, sobretudo, no que se refere aos campos de intervenção e análise.

Porém, é inevitável assumir que tal fato gerou em mim um sentimento de impotência por não identificar minha tese enquanto parte dos demais projetos de pesquisa, afinal, a ideia era que conseguisse articulá-los.

(...) o meu doutorado tem o objetivo de trabalhar unicamente com os apoiadores, os difere e isso é bastante importante: delimitar os projetos. (...) Um sentimento de dúvida e desânimo. Parece que o projeto não é mais meu (diário de pesquisa, 09/10/2015).

Isso torna evidente que a implicação aparece com o intuito de pôr fim às ilusões vinculadas à "neutralidade" analítica, indo na direção de que o pesquisador já se encontrava implicado no campo, além de que sua intervenção modifica o objeto de estudo e o transforma (LOURAU, 2004b).

O fato da modificação do objeto de estudo e a transformação do mesmo consiste em um processo que compõe o ato de pesquisar, sobretudo, quando nos referimos à pesquisas que possuem objetivos que se entrelaçam. Além disso, considero enquanto um processo de amadurecimento pessoal, profissional e também da própria pesquisa que compõe esta tese de doutorado, pois o objeto de estudo, dificilmente, aparece a priori. É natural que este vá sendo tecido e lapidado durante o percurso.

Segundo Romagnoli (2014, p. 50) “a implicação permite captar o aspecto 'trans' dos planos que compõem o objeto de estudo, mediante o rastreamento dos efeitos que provocam no campo e das (des)estabilizações que o campo produz no pesquisador" e foi nessa perspectiva 
que a participação nesses outros projetos de pesquisa me possibilitou, no mínimo, maior tempo para a realização da análise das minhas implicações com a pesquisa e a ampliação do olhar para as interferências institucionais a que estava exposto.

Assim, a experiência proporcionada por meio da minha inserção em projetos de pesquisa que caminharam em conjunto com a pesquisa-intervenção que compõe essa produção, oportunizou meu amadurecimento enquanto pesquisador e também a minha entrada no campo de intervenção da pesquisa que compõe essa obra, possibilitando um reconhecimento do território no qual eu me inseri para a produção dos dados. Somado a isso, foi possível aproximar-me de alguns trabalhadores que também foram sujeitos de ambas pesquisas, facilitando o agendamento das entrevistas e a realização das mesmas.

O “jeito mineiro", nesses momentos, chama-me bastante a atenção. Sinto a necessidade dessa aproximação afetiva junto às pessoas antes de interpelá-las. Consiste em um processo de saída da formalidade extrema para uma informalidade segura, atribuindo maior descontração ao processo - muitas vezes - enrijecido e capturado pela formalidade de realização de uma entrevista de pesquisa. Ser informal não consiste em fugir da seriedade no desenvolvimento de uma pesquisa. Muito pelo contrário, é uma tentativa de conseguir acessar o cerne do que pode surgir no encontro. Eu utilizei, para isso, da sensibilidade que a música e as diferentes artes me possibilitaram.

Essa aproximação e ida aos territórios para a realização das entrevistas também me proporcionaram confrontações com algumas implicações primárias. Exemplo disso, foram as dimensões ideológicas da minha implicação com o trabalho, especificamente, do enfermeiro na APS. Isso se tornava nítido quando surgiam, durante as entrevistas, algumas falas que indicavam o exercício da enfermagem na ESF, abordando uma perspectiva diferente daquela que eu acredito, apoio e compactuo, ou seja, que fugisse da dimensão ideológica da minha implicação com o trabalho do enfermeiro na ESF. Por vezes, saía das entrevistas desmotivado por perceber que a enfermagem na ESF, que possui uma potência imensa, não estava sendo colocada em prática da forma como é prevista, ou da forma como eu gostaria que ela fosse colocada em prática.

Saí da conversa chocado porque é uma profissional com formação totalmente privatista (...) Percebe-se que a dimensão ideológica da implicação profissional dela é outra que não o SUS. Ela acredita na perspectiva privatizadora, logo, não acredita no serviço público de saúde (...) creio que o embate ideológico me paralisou. Além disso, começamos a conversa a partir de uma enxurrada de reclamações da parte dela que, de alguma forma, me desestabilizou (...) Achei extremamente difícil essa conversa (...) Saio da entrevista engasgado, precisando falar (diário de pesquisa, 21/09/2016). 
Não apenas o trabalho do enfermeiro na APS compunha essas dimensões ideológicas da minha implicação com o trabalho, mas também a perspectiva com que as ações de EPS eram relatadas pelos sujeitos da pesquisa-intervenção. Quando essas ações se aproximavam de uma concepção de EC e, consequentemente, das estratégias que são colocadas em prática para a realização desse tipo de ação educativa, eu me sentia bastante incomodado, pois parecia-me existir uma falta de compreensão acerca do que vem a ser, de fato, a EPS. Ao mesmo tempo eu me questionava sobre qual seria a dificuldade desses sujeitos em compreenderem a diferença entre EPS e EC.

O que a gente mais consegue desenvolver é a parte teórica. Nós conseguimos montar todo o nosso projeto, conseguimos montar as aulas. Aplicar que é difícil. Iniciou (...) e depois disso começou a ser difícil as demais aulas (...) A minha parte de EP é toda baseada no curso de pós que eu fiz (...) Então, textos, material ilustrativo... tudo sobre o material que eu recebi no curso (AP06).

Essa implicação também foi modificando, indo ao encontro do princípio da Socioclínica Institucional de transformação que vai sendo produzida a partir do avanço do trabalho. Foi possível identificar apoiadores e articuladores se colocando em análise (e analisando suas implicações profissionais) nos encontros ocorridos com eles na cidade de Araraquara. Alguns que apontavam, em um primeiro momento, para o exercício da EPS e adotando uma lógica mais voltada ao modelo de EC, em outro momento passou a refletir acerca da sua concepção do que vinha a ser EPS e, consequentemente, transformar sua perspectiva, caminhando na direção do que é pautado pela PNEPS.

Não tem problema se eu não consigo desenvolver o projeto de EPS que eu elaborei. Se eu conseguir desenvolver parte dele, já seria ótimo. O que eu tenho que me atentar é que se, de fato, eu tenho colocado a EPS em prática (...) nas reuniões de equipe, no cuidado com os meus pacientes, na supervisão dos meus ACS... Acho que é por aí (...) Não são cursos teóricos. Estes também são importantes, mas a ideia é conversar com eles (...) é fazer eles pensarem sobre o trabalho deles, sobre o nosso trabalho na ESF (AP06).

Os relatos supracitados foram da mesma pessoa e é possível identificar o processo de transformação que a análise de implicação profissional possibilitou durante esse percurso da pesquisa-intervenção. Tal fato, inevitavelmente, fez com que a minha implicação (e a do participante supra-citado) com o desenvolvimento da EPS modificasse, passando de sentimentos de desesperança e desânimo para os de potência e reconhecimento de que as ações que estavam sendo colocadas em práticas, de fato, estavam surtindo processos de desterritorialização. 
Além disso, coloco em análise mais uma implicação: aquela estabelecida com a instituição universitária, dita e feita, sobretudo, por meio da relação com a minha orientadora de tese, afinal, a instituição fala por meio dos profissionais que compõem as organizações (LOURAU, 1993).

É necessário assumir a dificuldade de ter e poder falar sobre coisas que foram sendo construídas dialogicamente durante meu percurso de doutoramento. Questões que, obviamente, foram pré-tratadas e analisadas coletivamente antes de serem aqui expostas. Elas dizem um tanto do meu processo de análise de implicação quanto da análise de implicação da minha orientadora, que fizemos (e temos feito) coletivamente, afinal, a análise de implicação é mais potente quando feita no coletivo (LOURAU, 1993).

Ousaria dizer que minha implicação com a instituição Universitária, aqui representada pela minha orientadora, foi se transformando durante o percurso de doutoramento e, muito pelo fato de podermos falar sobre essa relação, analisá-la e lidarmos com essas análises de maneira coletiva e dialógica. Esse processo só foi possível graças à abertura ao diálogo que tanto eu quanto ela dispusemos e desenvolvemos nesse percurso, mesmo diante dos percalços físicos que nos impossibilitaram, por morarmos em cidades diferentes e que, por vezes, desfavoreceram o encontro. Mas estas interferências eram desviadas por meio, por exemplo, da utilização da tecnologia a nosso favor (com algumas ressalvas para o fato de que, nem sempre a tecnologia substitui o contato físico e o estar com o outro).

Tal proposição vai ao encontro do que Silva (2011, p. 92) relatou, fazendo uma densa análise das obras de Paulo Freire, de que "mesmo diante das impossibilidades objetivas, não se pode deixar de investir no diálogo verdadeiro e na luta pela transformação".

Na dimensão ideológica da minha implicação com a Universidade, minha orientadora reflete um tanto daquilo que eu gostaria de alcançar enquanto professor, orientador e pesquisador. Com temperamentos diferentes e estratégias de mediação que possuem suas particularidades, temos pontos em comum que, inclusive, nos fortalece nessa relação de aprendizado recíproco: eu aprendendo a ser docente e ela aprendendo a ser orientadora. Um aprendizado contínuo e por também acreditarmos nessa concepção - de que o aprendizado é permanente - colocamo-nos abertos aos defeitos e qualidades uns dos outros.

Antes de encontrarmos esse volume que agradasse tanto aos meus ouvidos quanto aos dela, foram necessários o percurso de algumas pautas, que dizem respeito do nosso processo de conhecimento e reconhecimento mútuos, afinal, o doutorado foi o primeiro contato de proximidade que estabelecemos. Para tanto, libidinalmente falando, alguns sentimentos permearam essa relação - e aqui, refiro aos meus sentimentos e não aos dela. Ciúmes por, em 
alguns momentos, estar mais voltada e direcionada a projetos e trabalhos de outros estudantes e não ao meu. Inveja de alguns estudantes que foram eleitos para desenvolverem projetos de dupla-titulação (Brasil e França) e não eu (apesar de compreender as questões institucionais desses processos, mas o sentimento foi inevitável). Orgulho por ela ter sido orientadora da primeira enfermeira do país a possuir dupla-titulação de doutorado, além das diversas aprovações de projetos, artigos científicos e conquistas, que pude presenciar durante meu percurso de doutoramento. Carinho que, por vezes, se confundiram com os de mãe (sobretudo, quando estive fora do país), mas que se transformaram em um sentimento fraterno e de parceria de trabalho.

Ainda com relação à dimensão libidinal, é inevitável não apontar para o fato dela ser mulher e da minha facilidade em conversar, trocar ideias e me sentir mais a vontade estando perto de mulheres. Sem dúvida, essa implicação tem a ver com aquilo que já foi descrito por mim nas notas preliminares, do meu crescimento permeado por figuras femininas e impregnado da manifestação de sentimentos como o carinho, o cuidado, o afeto, etc. Nesse sentido, foi e tem sido bastante desafiadora (e transformadora) minhas experiências como, por exemplo, de realização do estágio sanduíche com um orientador homem, onde pude, novamente, constatar a possibilidade de uma relação profissional permeada por sensibilidade e advinda do sexo masculino.

Na dimensão organizacional, ela e eu possuímos particularidades na forma de trabalhar. Ela consegue desenvolver várias coisas ao mesmo tempo enquanto eu procuro pelo foco em uma atividade e em seu desenvolvimento (contudo, também levando em consideração as transformações que o trabalho produz na medida em que avança, acredito ter aprendido com ela, durante esse percurso, a desenvolver diversas atividades ao mesmo tempo). Somado a isso, sou bastante adepto ao meio virtual e digital e, nesses sentidos, encontramos uma parceria que foi tecida muito mais por meio da complementação das características de um e de outro que pela repulsão pelas diferenças que possuímos. Para isso, valemo-nos, mais uma vez, da abertura ao outro e da necessidade de reconhecermos nesse outro um potencial para o desenvolvimento de atividades profissionais que fossem de qualidade.

Acho que a forma como a gente se coloca também legitima um lugar de "suposta superioridade" advinda do meio Universitário e que todas elas (professoras) parecem demonstrar uma abertura para uma relação horizontal, independente de sermos ou não estudantes (...). Eu falei da minha relação com a minha orientadora de tese, da tranquilidade e horizontalidade que tem sido trabalhar com ela e que não me sinto, em nenhum momento, observado e/ou tolhido por ela. Considero que tenho abertura para cometer falhas e que, caso 
isso aconteça, acredito que ela também terá abertura suficiente para chegar até mim e dizer (diário de pesquisa, 22/06/2017).

As transformações foram sendo realizadas por meio dos encontros e desencontros com a instituição universitária e as demais instituições que me atravessaram durante essa trajetória. Consistiu em um processo. Nesse percurso, procurei me atentar para sinais ou pistas que possibilitassem uma análise de implicação com a pesquisa, com a universidade, comigo mesmo (enquanto sujeito inserido em um contexto familiar, político, social, etc.).

As relações estabelecidas nas situações de pesquisa denunciam a exterioridade de forças que incidem sobre o pesquisador e a realidade que ele se propõe a estudar, e atuam como um rizoma, de maneira transversal, ligando processualmente a subjetividade a situações, ao coletivo, ao heterogêneo (ROMAGNOLI, 2014, p. 50).

Assim, fazemos a relação da análise de implicação com o referencial pedagógico da EPS, que constitui algo potente para a transformação de práticas. Fui percorrendo um caminho adotando "um lugar de atuação crítica, reflexiva, propositiva, compromissada e tecnicamente competente" (CECCIM, 2005b, p. 976), conforme é previsto pela EPS enquanto uma estratégia fundamental para as transformações do trabalho.

Nesse âmbito, afirmo que a análise das minhas implicações com várias instituições que me atravessaram durante esse percurso de doutoramento me possibilitaram o exercício da EPS em ato, uma ampliação do olhar para o trabalho em saúde, para o trabalho docente e, para além disso, uma emancipação enquanto sujeito-irmão, sujeito-filho, sujeito-companheiro, etc., pois “a implicação denuncia que aquilo que a instituição deflagra em nós é sempre efeito de uma produção coletiva, de valores, interesses, expectativas, desejos, crenças que são imbricados nessa relação". Portanto, é por meio da análise de implicação que acessamos a instituição, produzindo conhecimento (ROMAGNOLI, 2014, p. 47). E essa produção só foi possível porque a desenvolvemos na perspectiva de uma incorporação crítica dos discursos e movimentos de atores sociais, ampliando o padrão de escuta, favorecendo as relações com os apoiadores, articuladores e demais sujeitos que se fizeram presentes nessa produção.

Aqui, concluímos que a análise de implicação, enquanto um dispositivo analítico, foi capaz de gerar desterritorializações, tanto no pesquisador quanto na conformação de sua pesquisa. O Flávio e sua pesquisa do início do doutorado já não são mais o Flávio e a pesquisa que aqui se encontram. Isso se trata não apenas do percurso temporal em si, mas do debruçarse sobre os referenciais, sobre as análises e permitir-se ser analisado individualmente (por meio da redação no diário de pesquisa periodicamente) e coletivamente (nos diversos espaços de análise contemplados nessa obra). Tal perspectiva, caminha na direção do pressuposto 
contemplado nesta obra de que a análise de implicação profissional, ou seja, analisar a minha implicação com a pesquisa, com o apoio, EPS e com a enfermagem na ESF possibilitaram uma saída da "zona de conforto", uma maior reflexão acerca do sujeito-pesquisador, sujeitoenfermeiro, sujeito-companheiro, e demais sujeitos que me compõem.

Hoje consigo compreender um pouco mais o princípio da transformação produzida a partir do momento em que o trabalho socioclínico avança. A restituição de hoje foi maravilhosa. Pudemos falar sobre coisas jamais ditas e, inclusive, esse foi um dos feedbacks dados pela Coordenadora do CDQ-III, reafirmando a potencialidade da minha tese no trabalho que vem sendo desenvolvido com os apoiadores e articuladores. Não tenho dúvida de que meus pressupostos são verdadeiros e de que a análise de implicação profissional corresponde a um dispositivo potente para disparar processos de EPS nos territórios. Sinto-me bastante feliz com os resultados do encontro de hoje (diário de pesquisa, 21/09/2017).

E é a partir dessa análise que adentraremos ao $10^{\circ}$ ato onde continuaremos a abordar os resultados e análises feitas a partir das entrevistas e dos encontros com os apoiadores e articuladores no desenvolvimento da pesquisa-intervenção. 


\section{A ANÁlISE DE IMPLICAÇÃO PROFISSIONAL: A ORQUESTRA DOS APOIADORES DE HUMANIZAÇÃO E ARTICULADORES DE EPS}

Conforme exposto no ato precedente, assumimos a atitude ousada e "equivocada" de dividirmos as implicações a partir de suas dimensões com o intuito de facilitarmos a compreensão, acessibilidade e empregabilidade pelos profissionais de saúde que, porventura, vierem a ter contato com essa produção. A ideia consistiu em tornar a teoria mais palpável e prática sem, contudo, banalizá-la, atentando-nos para aquilo que foi possível ou não de ser colocado em prática a partir dos princípios da Socioclínica Institucional. Contudo, compreendemos que a "implicação é, para a Análise Institucional, um campo conceitual em que as fronteiras não são fixas e nem rígidas” (ROMAGNOLI, 2014, p. 48).

A partir das entrevistas individuais e grupais realizadas com os apoiadores de humanização e articuladores de EPS e também das anotações feitas no diário de pesquisa acerca dos encontros com estes sujeitos e dos encontros de planejamento e análise, configuramos um denso material que foi criteriosamente analisado a partir das dimensões da implicação profissional e é nessa direção que caminharemos a seguir.

\subsection{Dimensão ideológica}

Partindo do fato de que a dimensão ideológica faz menção àquilo que os sujeitos acreditam e que também é produzida a partir da existência social dos sujeitos (GARCIA, 1988), fizemos leituras exaustivas do material transcrito e das anotações feitas no diário de pesquisa com o intuito de identificarmos trechos que evidenciassem dimensões ideológicas da implicação profissional, ou seja, da relação ideológica estabelecida com o apoio e/ou com a articulação de EPS.

Nesse sentido, fizemos alguns agrupamentos de falas que refletiram um tanto dessa dimensão. Não se tratam, necessariamente, de analisadores, pois estes não foram construídos artificialmente, caminhando na direção de que os fragmentos de fala pudessem provocar o surgimento de alguns analisadores naturais no momento de restituição aos sujeitos que compuseram esta pesquisa-intervenção.

Uma questão que se destacou nas entrevistas, nas discussões dos encontros com os apoiadores e articuladores de EPS e que também esteve presente na restituição foi a questão do perfil para o exercício do apoio e da articulação. Os fragmentos a seguir explicitam essa questão: 
Então acho que é mais o meu perfil que levou a ter essa condução (AP07).

Então, sempre foi uma coisa tipo cargo de confiança, nunca foi como ele fez, do concursado estar lá e ele ver que aquela pessoa tem o perfil, gosta e escolher você (AP09).

Os apoiadores e articuladores falam tanto da necessidade de existir um perfil para o exercício da função apoio e articulação de EPS. Hoje mesmo, vários deles utilizaram essa palavra, muitas vezes para justificarem o trabalho desenvolvido ou a dificuldade em desenvolvê-lo (diário de pesquisa, 25/08/2016).

Eu acho que para começar o negócio tinha que falar assim: "você quer ser articulador?", "eu quero", "então, se você quer ser articuladora - tem o lance do perfil (AP14).

Em processo de restituição e análise dos fragmentos de fala acima aos sujeitos desta pesquisa-intervenção, apareceram duas dimensões de perfil. Uma ideia caminhou na direção do comprometimento, do envolvimento e do interesse do apoiador e articulador para o fazer apoio e articulação. Outra ideia disse respeito ao perfil enquanto uma competência para o desenvolvimento dessas duas funções; competência que, em um primeiro momento, parecia inata ao profissional (alguns possuíam outros não), como podemos perceber na seguintes falas:

Eu enxergo perfil, mas nessa questão do comprometimento (...) Eu vejo pessoas passarem e isso, no meio do caminho, se perde. A pessoa tinha interesse e acaba priorizando outras coisas (...) Qual a importância disso para a pessoa? (...) Em que momento ela pensa em trabalhar? Então, confunde perfil, interesse, comprometimento... (APE17).

Entendo que o que a colega traz sobre o perfil caminha muito na direção do comprometimento, mas também entendo o perfil enquanto aquilo que você traz, como uma implicação (engajamento), o quanto você está implicado com aquela função de articulação, de apoio e tal. Eu acho que um pouquinho mais além disso, esse perfil, para mim, tem a ver mais com as competências para desempenhar essa função e essas são de cada ser humano, de cada profissional (APE16).

Muitas são as produções científicas que vêm retratando experiências do apoio institucional em realidades distintas. Contudo, pouco se tem produzido acerca do perfil ou da necessidade (ou não) da existência deste para o exercício do apoio. Além disso, assumo aqui a minha sobreimplicação de pesquisador ao não explorar um pouco mais com esses sujeitos, durante e realização das entrevistas, acerca do que eles entendem ou queriam dizer quando se referiam à necessidade de existir um perfil para o exercício dessas funções. Parti da ideia de que a palavra em si já carregava consigo seu significado, mas sem saber ao certo se a minha compreensão de perfil consistia na compreensão apontada pelos apoiadores e articuladores e nem se estas possuíam congruência.

Fazendo um paralelo acerca da relação feita pelas apoiadoras e articuladoras de perfil enquanto comprometimento, alguns autores, ao tratarem, especificamente, do processo de 
formação de apoiadores, relataram que os desdobramentos dependem também da mobilização e do compromisso dos sujeitos para com a transformação dos processos de trabalho em saúde (SALGADO, PENA, CALDEIRA, 2014), indo ao encontro dessa noção de perfil vinculado ao comprometimento tanto com o exercício da função quanto com o processo de transformação do trabalho executado. Refutaremos em seguida essa ideia, sobretudo, por defendermos um processo de formação que difere de um modelo tradicional e instituído, onde existe, a priori, a necessidade de se alcançar competências para o exercício do apoio e da articulação de EPS, antes mesmo de colocar essas funções em prática. Para isso, prosseguiremos com as demais ideias e construções que foram surgindo durante o processo de análise coletiva com relação à temática do perfil de apoiadores e articuladores de EPS, mas retomaremos a esse apontamento.

Outras apoiadoras e articuladoras trouxeram uma concepção de perfil, que vai de encontro com a existência de comprometimento ou de competência para o exercício do apoio e da articulação, como podemos identificar a seguir:

Eu fico pensando se, de fato, existe um perfil para a função (...) Eu fiquei pensando se existe um perfil do apoiador e do articulador? É desejável que essa pessoa tenha isso, isso e aquilo. Então, em nenhum momento eu acho que foi colocado dessa forma, né? (...) Eu não sei se enxergo que tenha algo que seja pré-determinado, mas penso, muito mais, no que faz com que uma pessoa permaneça na função de apoio (APE19).

Eu lembro quando fui convidada para ser articuladora de EP, da conversa que tive na entrevista que fiz para esse projeto e essa questão do perfil sempre me incomodou. Por que? Por que que viram que eu tenho perfil se eu não vi? $\mathrm{O}$ que é esse perfil? Então, hoje eu entendi que ele pode ser construído (APE13).

Foi evidente que, com o passar das reflexões e problematizações realizadas em grupo acerca da (in)existência de um perfil para o desenvolvimento do apoio e da articulação de EPS, tal questão apareceu enquanto algo que poderia ser construída, produzida, desenvolvida e elaborada por meio das experiências profissionais e de vida. Não se tratam também de um processo de formação para o exercício da função, mas de algo que vai sendo apreendido durante o percurso de desenvolvimento do apoio e da articulação de EPS.

Mais uma vez é possível evidenciar por meio dos relatos que vêm sendo trazidos o princípio da Socioclínica Institucional das transformações que vão sendo produzidas na medida em que o trabalho avança (MONCEAU, 2013). Em se tratando do perfil do apoiador e articulador de EPS, identificamos as transformações que foram ocorrendo por meio dos encontros, da problematização das falas, que fazem menção direta às práticas profissionais dos apoiadores e articuladores. Ou seja, foi por meio da análise das práticas dentro da intervenção socioclínica que a análise de implicação profissional foi acontecendo, dentro da perspectiva da 
reflexão acerca do processo de trabalho desenvolvido pelos apoiadores e pelos articuladores de EPS.

Os apontamentos e as construções em análise realizadas com os apoiadores e articuladores de EPS refutam, portanto, a ideia da necessidade de existir um perfil e um comprometimento enquanto pré-requisitos para o exercício do apoio e da articulação. Estes parecem ser construídos com o passar do tempo e com o próprio desenvolvimento das funções de apoio e articulação de EPS.

Com o intuito de permanecermos no diálogo com outras produções científicas que vêm apresentando o perfil do apoiador a partir de sua formação universitária e pós-universitária, apresentaremos algumas interlocuções, procurando compreender um pouco mais (ou refutando tais apontamentos) a partir daquilo que já foi exposto previamente e trabalhado em processo de análise com os apoiadores e articuladores de EPS desta pesquisa-intervenção.

Fernandes e Figueiredo (2014) referem, em pesquisa realizada com os apoiadores de um município de grande porte do interior do estado de São Paulo, que $80 \%$ possuíam pós-graduação em seu currículo. Em contrapartida, 68\% não receberam nenhum processo de formação específica para o desenvolvimento do papel de apoio e $80 \%$ disseram não receber nenhum tipo de apoio ou formação continuada para o exercício da função.

Se observarmos o movimento das falas dos apoiadores e articuladores de EPS da presente pesquisa-intervenção e os dados apresentados no trabalho científico acima, poderemos concluir a existência de certo endurecimento e também da captura do trabalho vivo, ou seja, do aprendizado cotidiano vivenciado pelos apoiadores e articuladores de EPS no fazer apoio e articulação, por uma lógica que atribui a existência de competências pré-definidas para o desenvolvimento de determinada função, vinculada à participação em processos de formação institucionalizados.

São inúmeros os trabalhos científicos que vêm relatando acerca do fato de que o apoio se faz no encontro, no intermédio, enquanto tecnologia leve, onde se aprende fazendo (CAMPOS, 2007, 2017; MACHADO, MATTOS, 2015; PAVAN, TRAJANO, 2014). Ações de EPS que visam o acompanhamento, a problematização do apoio realizado e enquanto uma instância de cuidado e apoio aos apoiadores, devem ser encorajadas. É nessa perspectiva que o CDQ-III vem trabalhando. Os encontros mensais com os apoiadores e articuladores consiste em uma estratégia de desenvolvimento da EPS em ato e de apoio a estes, a partir de suas realidades, do trabalho realizado em seus municípios e das dificuldades enfrentadas para o exercício de suas funções. 
Portanto, cabe-nos questionar qual modelo de formação de apoiadores de humanização e articuladores de EPS está sendo pautado e implementado no país? Imbuído de diversas questões que compõem minha implicação ideológica de formação, com a pesquisa-intervenção em questão e também a partir dos resultados apresentados com relação ao (não)perfil dos apoiadores e articuladores, caminhamos na direção de que o investimento na formação deve ocorrer na perspectiva do desenvolvimento do encontro, ou seja, na perspectiva de colocar a EPS em exercício junto com os apoiadores e articuladores, pensando muito mais na perspectiva de uma formação que aconteça a partir dos respectivos contextos de vida, de trabalho e de ações executadas nos territórios. Parece desvincular da realidade a implementação de estratégias que fujam a uma lógica que não seja de acompanhamento das ações que estão sendo executadas pelos apoiadores e articuladores em seus municípios. Seria, mais uma vez, valorizar o trabalho morto em detrimento do trabalho vivo, pulsante, que tem sido (ou não) colocado em prática nos diversos territórios.

Assim, saímos um pouco da perspectiva do (não)perfil e adentramos nos agrupamentos de fala que remeteram a expressões de desânimo, pessimismo e otimismo no exercício do apoio e da articulação de EPS.

Tais relatos também caminham na direção da dimensão ideológica da implicação profissional, ou seja, naquilo que o trabalhador de saúde acredita (ou que é construído socialmente e incorporado por ele - consciente ou inconscientemente) como sendo um potencial ou não para o exercício do apoio e da articulação de EPS. Alguns fragmentos revelam um pouco mais dessas expressões:

Então, o que me sustenta aqui? O sentido? Eu não sei. Não sei mais. Pra te falar a verdade, eu não aguento mais isso de ser lembrada só na hora que convém (AP10).

Nossa! A minha sensação é que existiu um certo desânimo nos apoiadores e articuladores no encontro de hoje. Não consigo compreender muito bem se a quietude que eles estavam tem a ver com o momento político que muitos municípios vêm vivenciando ou se se trata dos desdobramentos do encontro e das reflexões geradas pelo encontro em si (ou das duas coisas) (diário de pesquisa, encontro com os apoiadores e articuladores 29/09/2016).

Porque nós somos duas teimosas, eu acho. A gente acha que dá (...) A gente ainda tem esperança de conseguir (AP14).

A gente não perdeu as esperanças, não é isso (...) Ainda bem que a gente sempre tem bastante esperança (AP12)

As dificuldades enfrentadas pelos apoiadores de humanização e articuladores de EPS em seus territórios advém de diversas frentes: desde o processo da busca cotidiana por garantir 
sua legitimidade e reconhecimento enquanto profissionais de saúde até o desenvolvimento do apoio e da articulação de EPS em si.

Machado e Mattos (2014) consideram o apoio como uma importante ferramenta de gestão, mas reconhecem que o mesmo vem passando por diversos desafios, dentre eles o próprio processo de desestruturação do trabalho das equipes de saúde, as condições inadequadas de trabalho, o investimento insuficiente na saúde e as dificuldades estruturais e gerenciais do trabalho em saúde.

Tais desafios não foram listados dessa forma pelos apoiadores e articuladores desta pesquisa-intervenção. Contudo, identificamos vários fatores que explicitaram um tanto do sucateamento do setor da saúde, dentre eles, o absenteísmo de alguns dos apoiadores e articuladores nos encontros mensais com o CDQ-III, justificado pela dificuldade de deslocamento até a cidade de Araraquara e alegando a ausência de transporte para fazê-lo ou algo do gênero. Tal fato, fornece-nos pistas para uma possível constatação dessa afirmação ou sugere questões de ordem organizacional, referentes ao estabelecimento de prioridades.

Certamente, desafios como os listados pelos autores e também constatados, conforme exposição acima, são capazes de despertarem sentimentos que atravessam o pensar e o fazer apoio e a articulação de EPS, imobilizando os apoiadores e articuladores. Ao mesmo tempo, existe, sobretudo no primeiro fragmento de fala, a utilização do trabalho do apoiador e do articulador enquanto valor de troca, ou seja, da sua utilidade por outrem a depender da conveniência.

Essa perspectiva nos remete à racionalidade gerencial hegemônica que captura e aprisiona a vontade dos sujeitos, expropriando suas possibilidades de executar um auto-governo de suas ações. Essa perspectiva gerencial, além de usufruir da força de trabalho, faz outras exigências aos seus trabalhadores, convidando-os a renunciarem de seus interesses, substituindo-os por normas e objetos de trabalho alheios as suas vontades. Consiste em tentar garantir o controle, até mesmo do pensamento dos sujeitos, buscando em troca o lucro e a alta produtividade (CAMPOS, 2007). Algumas outras questões relacionadas às relações de poder envolvendo, sobretudo, a gestão, serão também exploradas na dimensão organizacional da implicação profissional, pois foi possível colocar o modo de fazer gestão e o poder político em análise com os apoiadores e articuladores em momentos de restituição.

Contudo, ainda caminhando na perspectiva dessa racionalidade gerencial hegemônica, que busca, por princípio, resultados palpáveis, objetivos e centrados na linha de produção, o movimento de contabilizar, dar visibilidade e continuidade às ações desenvolvidas pelos apoiadores e articuladores também foi elencado enquanto uma dificuldade promotora de 
desânimo, pois é como se tivesse que provar para alguém, sobretudo para o gestor, os resultados do desenvolvimento do apoio e da articulação de EPS, não o conseguindo fazer segundo essa lógica:

Você vai fazendo, não consegue falar não, não faz algo completo, sempre começa, não termina, as coisas vão se acumulando, você vai se sobrecarregando, você é cobrado, você vai se cobrando e aí fica um desânimo (APE11).

É que o trabalho da EPS a gente não consegue definir muito bem. É como ela falou, a lógica está voltada ao procedimento. Aí eu não consigo dimensionar ou mostrar o meu trabalho. Números. E a EPS não trabalha nessa perspectiva, então ela não aparece (APE17).

É nítido o processo de captura da força pulsante e do sentimento produtivo proporcionado pelo encontro, pelo emprego das tecnologias leves e leve-duras no cuidado em saúde, pelas forças instituídas, sedimentadas e que resistem, a todo momento, ao aparecimento do novo, à provocação, à desterritorialização e ao surgimento de novas formas, potentes ou não, de fazer o apoio e a articulação de EPS. Essa força pulsante e viva é substituída por forças que estagnam, que interrompem e que cessam a força produtiva (YAHN, YASUI, 2014).

Contudo, ações de resistência têm sido criadas, compreendendo resistência como um jogo de forças; sendo uma social e a outra o poder, onde o equilíbrio entre elas tende a favorecer a segunda (MONCEAU, 1997). As expressões de persistência, otimismo e esperança relatadas por alguns apoiadores de humanização e articuladores de EPS caminham na direção de gerar forças instituintes, de desbalancear esse equilíbrio que favorece o poder que se encontra instituído, caminhando na direção da desterritorialização e do processo de institucionalização do fazer apoio e articulação de EPS.

Eu acho que isso pode levar àquilo que ela falou, da questão de você não ter visibilidade daquilo que você faz. Como, por exemplo, quando a gente lê a última frase "a gente ainda tem esperança de conseguir", isso se torna uma coisa ideológica (...). O que eu estou buscando? E isso se torna algo muito abstrato e, até dentro da pessoa que está fazendo, pode até se perder (...) eu vejo um pouco disso porque parece que você está sempre buscando algo que pode ser até inatingível (...) e é aí que surgem os sentimentos de otimismo, de esperança para se alcançar alguma coisa (APE20).

Por meio do fragmento de fala acima, identificamos também uma contradição. Ao mesmo tempo em que ela reforça o aparecimento do otimismo e da esperança enquanto forças que movimentam o apoiador e o articulador no exercício de suas funções, ela também direciona para a existência de uma "linha de chegada" pré-definida a ser alcançada por meio do apoio e da EPS. Nessa perspectiva, a construção coletiva não acontece e o apoio e a EPS parecem 
possuir, a priori, um ponto final. Não se pode alcançar esse lugar definido frente à premissa que move o apoio e a EPS: um encontro é o lócus de produção inédita, co-produção na qual não se pode antever o resultado.

Nesse sentido, Bichuetti (2011) traz a concepção de utopia ativa, que caminha muito na perspectiva do fragmento de fala acima, de se alcançar o desejo ${ }^{38}$ (consubstanciado numa vontade), mas gerador de potência que possui em sua essência dispositivos de luta. Ou seja, seria a busca de um ideal que gera movimentos em prol de seu alcance e não a estagnação da pessoa que o busca.

Contudo, a tentativa de se estabelecer uma meta individual e a priori e de quantificar as ações de apoio e de articulação de EPS nos remete à reprodução daquilo que se encontra instituído, deixando, mais uma vez, o trabalho vivo ser capturado e substituído pela valorização do trabalho morto. Somado a isso, dados qualitativos e quantitativos são possíveis de serem produzidos a partir das ações de apoio e articulação de EPS. Esses avanços e resultados são possíveis de serem evidenciados na micropolítica do trabalho em saúde (PINTO, FERLA, 2015).

Portanto, há que se pensar na perspectiva da melhoria do acesso e da qualidade dos serviços de saúde prestados à população, no aperfeiçoamento e emancipação do trabalhador de saúde a partir do seu processo de trabalho, na promoção e alcance da articulação de redes de serviços segundo uma concepção diferente dessa lógica sedimentada e instituída. São aspectos que se aproximam de um outro modelo gerencial e de uma outra ordem temporal, conforme foi possível identificar, por meio dos fragmentos de fala que seguem e que demonstram o deslocamento na concepção dos apoiadores e articuladores acerca dessa questão, um processo alcançado a partir dos espaços de restituição e análise coletiva das implicações profissionais:

Não dá para dimensionar o trabalho (...) Se ele é resolutivo ou não, talvez tenha uma questão com... por exemplo: você só vai saber ou não se aquela Unidade avançou no processo de trabalho dela se eles conseguirem perceber que o modo como eles têm trabalhado não tem favorecido, por exemplo, a chegada de alguma demanda até a Unidade. Aí sim, você vai conseguir visualizar e, de certa forma, quantificar o seu trabalho (APE16).

Eu acho que assim, as nossas ações devem estar pautadas na nossa realidade. Por exemplo: isso tem que estar pronto, $100 \%$, isso foge da realidade (...) ao mesmo tempo que você tem que ser otimista, você tem que estar pautado na realidade. Isso é possível de se chegar? Não adianta confundir otimismo com teimosia (APE21).

\footnotetext{
${ }^{38} \mathrm{O}$ conceito de desejo para essa obra será melhor explorado no sub-ato da dimensão libidinal da implicação profissional.
} 
Assim, compreendemos na prática que se o homem sofre por meio das instituições que o atravessam, ele também é responsável por criá-las e mantê-las viva "por meio de um consenso que não é somente passividade diante do instituído, mas igualmente atividade instituinte, a qual, além disso, pode servir para pôr em questão as instituições” (LOURAU, 2004, p. 73).

$\mathrm{Na}$ sessão de restituição foram apresentadas aos apoiadores e articuladores de EPS alguns fragmentos de falas de entrevistas que ilustravam análises que estávamos realizando. Em determinado momento identificamos a existência de uma visão teórica acerca da EPS um pouco equivocada e que reflete, diretamente, nas ações que são executadas e colocadas em prática no exercício do apoio e da própria articulação de EPS. Tal perspectiva, conforme já exposto na análise das minhas implicações, foram de encontro com as dimensões ideológicas do que vem a ser apoio e articulação de EPS para mim. Alguns fragmentos de fala explicitam claramente essa questão:

(...) eu dou a mesma coisa duas vezes para poder pegar as duas equipes (...) e poder não deixar a Unidade de Saúde fechada (AP06).

A minha parte é a de EPS. Ela fala da atenção básica e eu falo de EPS (...) Eu fico na parte das diretrizes. Eu não fiquei focada na teoria, porque conta com mais dinâmica, mais vídeo (...) Então, eu montei tudo (AP22).

O aspecto identificado por meio da revisão integrativa de artigos científicos realizada nessa obra e o que se encontra explicitado na análise feita acerca daqueles achados, também é constatado aqui, na prática. Consiste no processo de institucionalização em que a EPS se encontra. Essa dialética composta por forças instituintes geradas pelas próprias apostas feitas pela PNEPS e por forças instituídas, mesclam-se. Contudo, parece compor uma mistura heterogênea, onde os diluentes (EPS e EC) não se misturam ou o fazem momentaneamente, quando provocado, quando agitados de maneira intencional. Mas, ora um diluente é mais evidente, ora outro, ambos aparecendo por meio das falas e ações colocadas em prática.

A fuga daquilo que é hegemônico dificilmente ocorre sem dificuldades (PINTO, FERLA, 2015). Não seria diferente no caso do emprego da EPS em ato. Peres et al. (2016) também identificaram a dificuldade de gestores e outros trabalhadores de saúde compreenderem o que vem a ser EPS e quais ações caminham na perspectiva de colocá-la em prática nos territórios.

Tais constatações colocam em evidência o modelo tradicional de formação profissional, ainda centrado no conteúdo e na prática pedagógica de transmissão do conhecimento. Esse modelo, descontextualizado e desintegrado da realidade do trabalho em saúde, de fato, não tem se demonstrado efetivo para o alcance da aprendizagem, haja visto a constatação aqui 
explicitada e também evidenciadas por meio de diversas produções científicas acerca da temática (COSTA, BORGES, 2015; COSTA et al., 2015; PEDUZZI et al., 2013; SILVA, PEDUZZI, 2011; PEDUZZI et al., 2011).

Além disso, o que novamente nos chama a atenção é também a dificuldade que os apoiadores e articuladores possuem em produzir encontros, utilizando-os enquanto uma ferramenta para o desenvolvimento do apoio e da articulação de EPS. Isso aparece, inclusive, por parte de apoiadores e articuladores, enquanto proposta de desdobramento de um momento de restituição, momento em que encontrávamos em processo de análise de nossas implicações profissionais, podendo ser evidenciado por meio dos relatos que seguem:

Eu lembro que antes eu pensava em como eu poderia trabalhar e fazer aparecer o meu trabalho (...) se eu começar, portanto, a fazer as pessoas se encontrarem, se reunirem e gerar conflitos, já é um bom começo... dá pra fazer um trabalho que eu consigo enxergar (...) eu precisava dessa situação concreta pra entender o trabalho (...) é um primeiro passo pra gente conseguir realizar o trabalho (APE17).

Não. Vamos parar com isso. Se dois ou três aderirem, vamos aproveitar com eles para modificar depois. Eu acho que, com o fluir do trabalho, você consegue contagiar outras pessoas. Então vamos começar a fazer (APE21).

Silva, Barros e Martins (2015, p. 1161) falam, exatamente, do apoio enquanto uma tecnologia relacional, que parte do pressuposto de que "a produção de saúde não se faz sem a produção de sujeitos corresponsáveis e autônomos nesse processo". Assim, cabe ao apoiador e articulador de EPS facilitar diálogos, mediar conflitos, ampliar as possibilidades de reflexões e trazer ofertas relevantes ao processo de trabalho da equipe de saúde (PEREIRA JÚNIOR, CAMPOS, 2014).

Finalizando o sub-ato da dimensão ideológica, identificamos e colocamos em análise alguns trechos que retratavam acerca da recompensa enquanto um feedback positivo ao desenvolvimento das funções de apoio e articulação de EPS, como seguem:

E eles vêm trazer alguma coisa de volta, ás vezes vêm agradecer, vêm sempre com presente. Então é o reconhecimento que eu acho muito importante (AP01).

Fico pensando acerca da forma como os encontros mensais com os apoiadores e articuladores têm sido programados. Parece não existir tanta interferência externa (não tem um coffee break maravilhoso, por exemplo) que os façam querer estar presentes nesses espaços. Eles têm vindo. Isso demonstra um tanto do funcionamento dos dispositivos colocados em prática (...). Ás vezes fico refletindo acerca da remuneração destes profissionais. Como seria se existisse uma recompensa financeira para o desenvolvimento do apoio e da articulação de EPS? (diário de pesquisa, 20/04/2017). 
É interessante observarmos o quanto a satisfação do ego (e aqui também poderíamos dizer da concretização do desejo, indo na direção da dimensão libidinal da implicação profissional, que será trabalhada em um sub-ato seguinte) é capaz de movimentar os corpos. Nessa direção, é possível compreender quando Salgado, Pena e Caldeira (2014) relatam que as questões pessoais também influenciam no engajamento dos trabalhadores no exercício de suas funções.

Contudo, o dinheiro, enquanto um dos analisadores mais sensíveis da Socioanálise (LOURAU, 1997), seria mais uma questão que possibilitaria fazer com que as instituições apoio e articulação de EPS falassem. Nesse sentido, deparamo-nos com a nossa sobreimplicação em não colocar a ausência de remuneração para o desenvolvimento dessas funções em análise, pois se o dinheiro constitui em um analisador potente, "que permite esclarecer dimensões fundamentais e muitas vezes ocultas e contraditórias das relações entre os sujeitos que constituem uma organização" (L'ABBATE, 2004, p. 88), a sua ausência também poderia consistir em um potente analisador. Tal afirmação caminha na direção de que as instituições são transversais, ou seja, são atravessadas o tempo todo por diversos níveis da formação social, não podendo ser consideradas enquanto um nível, pois se encontram presentes também em todos os outros (LOURAU, 2004).

E é partir de então que adentraremos à dimensão organizacional da implicação profissional dos apoiadores e articuladores de EPS, reafirmando nossa compreensão de que essas dimensões encontram-se imbricadas entre si e que, algumas questões organizacionais e libidinais já foram aqui expressas, mas deverão ser retomadas nos próximos sub-atos. Compactuamos com a afirmação de que nós funcionamos por meio dos fluxos que nos atravessam e dos quais também somos resultado (ROMAGNOLI, 2014).

\subsection{Dimensão organizacional}

A dimensão organizacional da implicação profissional diz respeito à base material e organizacional (como o próprio nome sugere) que o sujeito estabelece com a profissão, nesse caso, com o apoio e articulação de EPS. Assim, a partir do agrupamento de alguns trechos que remetiam a essa dimensão nas falas dos apoiadores e articuladores de EPS, foi possível identificar alguns analisadores, que foram colocados em reflexão nos encontros de restituição.

A ideia consistiu em expor aquilo que se encontrava evidente a partir da leitura das entrevistas e dos encontros com os apoiadores e articuladores e, a partir dali, problematizar 
algumas questões, "fazer as instituições falarem", provocando o surgimento de novos analisadores.

Ou seja, a análise de implicação foi colocada em prática na perspectiva da EPS, problematizando o fazer apoio e a articulação de EPS, retomando relações estabelecidas com as diversas instituições que atravessam o cotidiano do profissional de saúde em suas organizações e que, geralmente, são banalizadas e ignoradas, não sendo colocadas em análise dentro da rotina organizacional (MOURÃO et al, 2012).

$\mathrm{Na}$ exposição do quadro que sistematizava a disposição dos participantes das entrevistas a partir de suas formações profissionais, foi possível identificar e analisar os atravessamentos e interferências que a profissão inicial dos apoiadores e articuladores exerce no fazer apoio e na articulação de EPS. Portanto, podemos tomar o "quadro das profissões" enquanto um analisador, que surgiu a partir do processo de restituição dos dados da pesquisa e que colocou em evidência a instituição "profissão", especificamente de enfermagem, em análise.

Tabela 3 - Disposição dos entrevistados a partir de suas formações profissionais

\begin{tabular}{l|c}
\hline \multicolumn{1}{c|}{ Formação Profissional } & Quantidade \\
\hline Administração & 1 \\
Fonoaudiologia & 1 \\
Enfermagem & 16 \\
Fisioterapia & 3 \\
Nutrição & 2 \\
Psicologia & 6 \\
Psicopedagogia & 1 \\
Terapia Ocupacional & 3 \\
Odontologia & 1 \\
Farmácia & 1 \\
\hline
\end{tabular}

Fonte: Entrevista com os sujeitos que compuseram a pesquisa-intervenção em questão (2016-2017)

É possível identificar a grande quantidade de enfermeiros no desenvolvimento do apoio e da articulação de EPS. Ao problematizarmos e analisarmos essa evidência, esbarramos também nas questões referentes à prática profissional do enfermeiro e o quanto a enfermagem atravessa e está presente nos relatos das entrevistas proferidas por eles, como se pode perceber a partir dos fragmentos que seguem:

E pensando mais um pouco nessa questão de análise de implicação (...), eu levo uma questão sempre comigo que é o fato de ser enfermeira (AP16).

É uma coisa que eu gosto, mas ás vezes eu me sentia frustrada - não sei se frustrada é a palavra certa. Porque eu não conseguia estar fazendo (as atividades de EPS) e parar. Por exemplo, se a gente está na reunião e tiver uma 
emergência, eu, enquanto enfermeira, teria que parar e estar ajudando lá na emergência (AP15).

Então, a enfermeira assistencial é a enfermeira boazinha da unidade. Eu queria ser a assistencial, a enfermeira boazinha (...) provocar reflexões gera conflito, gera desconforto (AP03).

A profissão de enfermagem, que carrega consigo um imaginário social de chefia, controladoria, rigor técnico, sistematização e planejamento de ações, foi também colocada em análise junto aos apoiadores e articuladores de EPS em encontro de restituição. Permeado por diversos desconfortos ao constatarem o quanto carregam da formação profissional no desenvolvimento das funções de apoio e articulação de EPS, um dos participantes trouxe, em avaliação do encontro, o sentimento de tristeza pelo fato dos enfermeiros não conhecerem sua própria profissão. Tal dado empírico corrobora com o fato de que analisar a implicação consiste em uma tarefa difícil, árdua (LOURAU, 2004).

Essa consideração, remete-nos diretamente à sobreimplicação profissional, ou seja, à "cegueira" em conseguir visualizar relações estabelecidas com a instituição profissional e a dificuldade de tomá-la em análise. É a partir da análise das nossas implicações profissionais que nós podemos compreender melhor a nossa função e transformar a nossa prática (MOURÃO et al, 2012).

Penido (2015) também constatou que a análise de implicação pode contribuir para que os sujeitos percebam algumas crenças que contribuem no tensionamento e execução do trabalho, sobretudo, em equipe. E, nessa perspectiva, nada mais notório que o emprego da análise de implicação em ato, enquanto um potente dispositivo disparador de processos de reflexão da prática profissional, ou seja, causador de desterritorializações no sentido do fortalecimento das ações de apoio e da articulação de EPS.

Alguns relatos explicitam esse processo de desterritorialização por meio da reflexão acerca do ser enfermeiro e das atribuições que este profissional carrega consigo:

Um dia eu ouvi em uma palestra uma pessoa dizendo que o único profissional
que sabe mandar é o enfermeiro. Que ele se apropria disso e quando começa
a trabalhar já sai mandando. Mas fico pensando agora. Por que isso? Isso me
consome. Eu tenho que dar conta da assistência, da área gerencial e, além de
tudo, dos outros profissionais que são de nível superior como eu dentro da
equipe (APE25).

Tomando a história da profissão de enfermagem, constatamos algumas ações que são desenvolvidas por enfermeiros na atualidade e que advém dessa construção histórica da profissão. Ela, enquanto instituição, surgiu a partir da necessidade de organização do ambiente e separação das morbidades, ou seja, a partir do processo de organização e gerenciamento do 
trabalho em saúde. Contudo, o que a análise de implicação propõe é, exatamente, questionarmos acerca de como essa organização e gerenciamento do trabalho em saúde (e em enfermagem) têm sido feitos e por que isso compete apenas ao profissional de enfermagem?

Caminhando na perspectiva das transformações que a intervenção socioclínica vai provocando, um relato de um apoiador possibilita algumas pistas no sentido de esclarecer o porquê da enfermagem se colocar e permanecer nesse lugar instituído, de gerenciamento e organização do trabalho em saúde:

Eu estou entendendo o porquê disso. A gente, na formação profissional, na faculdade, na Universidade - não sei se tem outros hoje - mas a enfermagem ela tem uma parte que é de administração. A gente tem administração na Universidade. Então, a partir desse momento, eu fico pensando: Poxa o que eu tinha que fazer naquela lavanderia do hospital, quando eu fazia estágio? Eu tinha que entender o tecido, o produto... quem é o outro profissional que vai ver uma lavanderia de hospital? Psicólogo? Fisioterapeuta? Eles não vão (...) então a gente sai com isso nas costas (APE 25).

Nessa perspectiva, temos que as profissões são construídas pelos próprios profissionais, mas com a existência de inúmeras interferências institucionais como, por exemplo, de outras profissões, da política, dos saberes, etc. (MONCEAU, 2008a).

Outro analisador que surgiu a partir da leitura das entrevistas e que remete à dimensão organizacional da implicação profissional dos apoiadores e articuladores de EPS consiste no tempo. A fala seguinte retrata essa dimensão:

Nós não conseguimos trabalhar nada com eles porque você chega lá... O que nós vamos poder fazer? Mais um trabalho? Mais uma coisa? Como você quer que eu desenvolva um trabalho melhor sendo que nós estamos trabalhando mais do que no limite? (AP01).

O tempo destinado ao desenvolvimento do apoio e da articulação de EPS pode indicar parte da dimensão organizacional da implicação profissional. Essa afirmação é possível de ser realizada quando se constata, por meio do fragmento de fala, a maneira com que o tempo tem sido utilizado pelo profissional de saúde no exercício de suas funções. No fragmento acima, apreendido por meio de uma das entrevistas, demonstra aquilo que se encontra instituído e presente na retórica cotidiana dos apoiadores, articuladores de EPS e dos profissionais de saúde em geral: a falta de tempo para o exercício de suas funções.

Esse analisador colocou em evidência a dimensão organizacional da relação que o apoiador e o articulador estabelecem com o fazer apoio e articulação de EPS, como podemos perceber por meio do relato que segue: 
Eu não me vejo exaurida das sete da manhã ás quatro da tarde de segunda a sexta, dentro da Unidade. Eu tenho tempo para fazer. Existem momentos em que a gente tem picos na Unidade e existem momentos em que as coisas se acalmam... todos os dias isso acontece. Eu já trabalhei em quatro Unidades, de cidades muito grandes e cidades muito pequenas, já trabalhei em Unidades rurais e unidades urbanas... e é sempre a mesma rotina, mais ou menos. Então, eu, dentro da minha organização (...) eu não me enxergo trabalhando mais do que no meu limite (APE 25).

Então, tomando o tempo enquanto um analisador das implicações profissionais, temos que este é contado (como o dinheiro), mas o mesmo não pode ser resgatado, apesar de poder ser remunerado. "Na atividade profissional, são as quantidades de tempo (de trabalho) a ser executado que são objetos de difíceis negociações" (MONCEAU, 2012, p. 54, tradução livre do autor $\left.{ }^{39}\right)$.

O tempo possibilitou problematizar se o desenvolvimento do apoio e da articulação de EPS consistem em escolhas pautadas em normas e regras estabelecidas a priori como, por exemplo, a dicotomia existente entre o apoio e a articulação versus a assistência à saúde:

Eu fico pensando que, quando você está na função assistencial, fica difícil. Então, chega uma gestante lá, buscando atendimento, você vai largar a gestante para realizar uma reunião? A gente fica dividida (...) Chega um paciente, com uma queixa, você precisa fazer um atendimento ou determinado procedimento, você vai largar o paciente lá e vai fazer a reunião? (...) mesmo quando chega o meu horário, eu vou deixar a pessoa lá e vou embora? (APE27).

O tempo evidencia a interferência institucional que a profissão do apoiador e do articulador exerce sobre o fazer apoio e articulação. Peres, Silva e Barba (2016) também identificaram a escassez de tempo, revestida pela justificativa de uma rotina intensa de trabalho dos profissionais de saúde, enquanto uma das dificuldades para o desenvolvimento da articulação de EPS.

Alguns autores defendem a destinação de uma carga horária específica, dentro daquela desenvolvida por profissionais que também se encontram na assistência à saúde direta, e, até mesmo, a adoção de estratégias como a implementação de portarias ou leis que busquem formalizar o exercício do apoio nos municípios, vislumbrando garantir o apoio e a articulação de EPS àqueles que desenvolvem ambas funções em seus municípios (MACHADO, MATTOS, 2015). Tal perspectiva também foi possível de ser identificada na fala de um articulador de EPS:

\footnotetext{
39 "Dans l'activité professionnelle, ce sont des quantités de temps (de travail) à venir qui sont objets de tractations" (MONCEAU, 2012, p. 54).
} 
eu e a apoiadora de humanização. Mas não é uma coisa que está assim... é uma coisa que, sabe, acontece. "Chama lá pra ajudar". (Não é uma coisa) instituída, legitimada pela própria Secretaria da Saúde. Eu acho que eles nem sabem exatamente que existe esse tipo de coisa (AP10).

Essa perspectiva de tentar garantir uma carga horária específica para o desenvolvimento do apoio e da articulação de EPS parece caminhar, mais uma vez, na direção da captura do trabalho vivo e valorização do trabalho morto, atravessando e enrijecendo o apoio e a articulação enquanto tecnologias leves, que se fazem por meio do contato com o outro, por meio do encontro. Seria uma reprodução de um modus operandi pautado na lógica da verticalização das ações, centrando a atenção no apoio e na articulação enquanto meras ferramentas a serem colocadas em prática a qualquer custo.

Isso tem muita relação com o processo de gestão, que atravessou todas as dimensões da implicação profissional dos apoiadores e articuladores de EPS nesse estudo. Nesse sentido, o modo de fazer gestão também compôs outro analisador presente no agrupamento de falas trazidas pelos apoiadores e articuladores nas entrevistas:

É, ela como Secretária trazia, ela sabia o que tava acontecendo lá, então ela trazia pra reunião o que tava acontecendo pra se trabalhar, pra gente construir e realizar um trabalho lá naquela unidade. Então, era sempre assim que acontecia (AP04).

Nosso problema não é mais gestão, nosso problema agora é o restante da equipe (...) Nós não temos dificuldade com a gestão (AP06).

É possível verificar, por meio das falas acima e de outras que compuseram o material das entrevistas com os apoiadores e articuladores de EPS, a existência de um certo grau de compartilhamento de ideias entre gestão, apoiadores e articuladores. Contudo, tal evidência não é uma constante em todos os municípios que participaram do presente estudo. Além disso, a relação evidenciada acima parece possuir muito mais uma característica de uma divisão técnica e social do trabalho, onde a gestão pensa e os apoiadores e articuladores executam aquilo que é direcionado por ela. Tal fato, ilumina as relações de poder que se encontram instituídas, pois, no momento em que há compartilhamento do poder dentro dos coletivos de trabalho, os esquemas de dominação são alterados, sendo necessário o estabelecimento de novas estratégias de contratos e pactuações entre os sujeitos, para que haja uma efetiva intervenção na realidade (CASTOS, ANÉAS, 2017).

Ora, considerando o apoio institucional, previsto na PNH, enquanto: 1) um dispositivo de intervenção direcionado às mudanças requeridas pelo SUS com o intuito de reafirmá-lo enquanto política inclusiva e universal (SALDANHA et al, 2014); 2) um método da própria 
gestão com o intuito de elaborar, implementar e executar projetos e políticas públicas, fortalecendo a construção de sujeitos individuais e coletivos (PEREIRA JÚNIOR, CAMPOS, 2014); 3) uma ação política, clínica e institucional na medida em que gera interferência, sendo que o apoiador se encontra nos espaços concretos em que a vida pulsa, aberto às possibilidades de mudanças, às brechas, no "entre": sujeitos, saberes, poderes, instâncias de atenção, instituições e entre a atenção e a gestão (PAVAN, TRAJANO, 2014); não há como apartarmos a gestão e os assuntos tratados nessa instância da função exercida pelo apoiador e articulador de EPS. Tal perspectiva, soa-nos, no mínimo, incoerente, indo na contramão da questão central do desenvolvimento do apoio e da articulação de EPS.

O apoio institucional, em si, é uma forma de fazer a gestão participativa, fortalecendo os menos aptos e fazendo junto, reconhecendo o problema e oferecendo um apoio diferente do paternalista, mas direcionado à educação dos sujeitos, levando recursos de educação e saúde para as equipes com maiores dificuldades (CAMPOS et al, 2017). Parece-nos evidente a aproximação entre a PNH e a PNEPS por meio da constatação do processo formativo no exercício da função apoio, sendo possível identificar a articulação objetiva entre o apoio institucional, enquanto dispositivo da PNH, e a problematização do trabalho da PNEPS.

Ademais, a perspectiva proposta por Campos (2007) do exercício da cogestão (ou gestão compartilhada entre os sujeitos) e a necessidade da existência de uma intersetorialidade na construção de uma rede de cuidados, é algo fundamental para garantir a atenção às necessidades apontadas pelos usuários e identificadas pelos profissionais de saúde (SALDANHA et al, 2014). Portanto, há que priorizar as necessidades de saúde, sem levar em consideração os interesses individuais de governantes, dos partidos e grupos políticos para que as ações desenvolvidas sejam efetivas e que caminhem na direção daquilo que é previsto enquanto princípios e diretrizes do SUS.

E em se tratando das questões que envolvem o poder político de governantes, adentramos ao último analisador da dimensão organizacional da implicação profissional no exercício do apoio e da articulação de EPS, que foi construído a partir dos relatos dos apoiadores e articuladores nas entrevistas. Os seguintes fragmentos de fala explicitam os atravessamentos da ordem desse poder vivenciados nos cotidianos de trabalho pelos participantes deste estudo:

Não, com certeza intimida, às vezes chegava a mãe do vereador assim, não só a equipe, então a gente acaba sendo intimidado por isso. Às vezes, chega a mãe do vereador, vamos atender... (AP03).

Eles (usuários) vão voltar com vereador, com prefeito... (AP03). 
Acho que esperando o ano acabar, ser exonerada, ver se alguma coisa melhora... Não sei, né, se esse pessoal que está aí vai embora e entra alguém que tenha outra visão da coisa... Não sei. (AP10).

Aí é a tal da política que sempre está atrapalhando o negócio (AP06).

Segundo Foucault (1979), toda relação se encontra permeada pelo poder e a intenção da Análise Institucional não consiste em negar ou velar essas relações de poder. Pelo contrário, a Análise Institucional se propõe a revelar essas relações, colocando-as em análise.

Pelo fato da PNH e PNEPS se tratarem de políticas de Estado, elas passam a consistir em objetos de disputa, sendo que nas sucessivas trocas de governo, elas são submetidas à barganha, ao desvirtuamento, à substituição (CECCIM, 2005b). Elas foram escolhidas enquanto exemplos que apostaram nas várias formas de interação, tendo como foco o processo de trabalho em saúde. Ambas apostam no apoio institucional enquanto um dispositivo (PINTO, FERLA, 2015) e é, nessas perspectivas, que elas não deveriam entrar em pauta nas disputas político-partidárias.

Alguns relatos proferidos pelos apoiadores e articuladores em momentos de análise coletiva demonstraram o quanto o poder político interfere no fazer apoio e articulação de EPS, que, nas realidades em questão, estão vinculadas à indicação direta para o exercício destas funções. Portanto, consiste em uma ligação entre a vigência político-partidária do momento e o exercício das funções:

Depende de quem está naquele momento na gestão (...) vai depender do gestor. Já existiu gestor que a gente nunca conseguiu falar com ele (...) eu até acho que estar na geladeira é bom. A gente vivencia o pior lugar. Quando a gente sai dele, a gente já conhece o pior, então fica difícil a gente assustar com outras coisas (APE31).

Alguns espaços a gente até pode questionar a cogestão e tal. Em outros espaços é difícil de questionar. Dá medo de ser colocado na geladeira de novo, sabe? Eu já estive nesse lugar e eu não queria voltar (APE20).

O apoio e a articulação de EPS deveriam ser entendidos enquanto funções vinculadas à políticas públicas, que deveriam ser implementadas no país obedecendo suas normativas e desvinculadas do governo que está em vigor na instância executiva. Um estudo realizado em um dos municípios que compõe a pesquisa-intervenção em questão e que traz acerca dos desafios e potencialidades do processo de execução da EPS na cidade, também identifica esse processo cíclico dos andamentos e retrocessos acerca do desenvolvimento das ações de EPS, em se dependendo das transições político-partidárias (PERES, SILVA, BARBA, 2016).

Não há como escapar à captura dos interesses político-partidários no exercício das ações em saúde no Brasil? Eles configuram em mais uma potente interferência institucional às ações 
desenvolvidas pelos profissionais de saúde em seus cotidianos. A dicotomia existente entre o interesse público e o privado é uma constante no país e há quem diga se tratar de heranças ibéricas na composição do povo brasileiro (YAHN, YASUI, 2014). Em se tratando ou não, não cabem ilusões ou idealizações, pois o sonho ou a ilusão são questões distinguíveis entre si: existe o sonho da EPS e da PNH serem, efetivamente, empregadas nos cotidianos dos serviços de saúde enquanto políticas de Estado. Contudo, suas implementações enfrentam (e enfrentarão) paradoxos da própria contra-hegemonia inerente as suas proposições (CECCIM, 2005).

Ademais, vale frisar o fato da potencialidade da micropolítica do trabalho vivo, ou seja, da execução das ações de apoio e articulação de EPS no cotidiano pulsante dos serviços de saúde, nos encontros estabelecidos entre profissional de saúde e apoiador e articulador. Acreditamos que o processo de institucionalização dessas políticas por meio de mecanismos instituídos como, por exemplo, promulgação de portarias e leis não, necessariamente, garantem a materialização das funções de apoio e articulação nos cotidianos dos serviços de saúde. E é nessa materialização que se dá na rotina do processo de trabalho em saúde que apostamos enquanto uma potência para a geração de forças instituintes no sentido da implementação, de fato, dessas funções no SUS.

Para se incorporar o exercício efetivo do apoio e da articulação de EPS na prática dos serviços públicos de saúde será necessário um start disparado por meio da valorização dos micros espaços e dos encontros entre os trabalhadores, caminhando na perspectiva do querer fazer, do desejo em colocar isso em prática. Tais possibilidades caminham na direção da dimensão libidinal da implicação com o fazer apoio e articulação em EPS, adentrando no próximo sub-ato que segue.

\subsection{Dimensão libidinal}

Partindo do fato de que a dimensão libidinal está relacionada ao desejo e ao afeto dos sujeitos e que, segundo Lourau (1993), as implicações libidinais estão presentes em qualquer situação da vida, o tempo todo; iniciaremos esse sub-ato por meio da definição de desejo adotada nessa obra. Para isso, utilizaremos das concepções de Deleuze e Guatarri que o define como sendo algo que se dá a partir de uma construção coletiva, desfocando da ideia de uma subjetividade de sujeitos isolados de um contexto (GUATARRI, ROLNIK, 2016).

Assim, realizamos o mesmo movimento feito na dimensão libidinal, ou seja, agrupamos alguns trechos de falas das entrevistas com os apoiadores e articuladores de EPS, que refletiram 
acerca dessa dimensão e colocamos em análise coletiva nos momentos de restituição. Vale lembrar do embricamento existente entre as dimensões que compõem a implicação. Portanto, para se evitar a repetição de análises já abordadas, sobretudo, na dimensão ideológica, traremos neste sub-ato apenas o que surgiu de novo e que ainda não foi contemplado nos sub-atos precedentes.

Um fator que chamou bastante a atenção fez referência ao desenvolvimento do apoio e articulação de EPS articulados à necessidade de agradar os profissionais de saúde no exercício dessas funções. Trata-se de ser identificado enquanto um parceiro e não um "gerador de novas demandas de trabalho" às equipes de saúde, como se pode constatar por meio dos seguintes fragmentos de fala:

A gente vai perguntar de problema? Vai surgir um monte. Vai fazer o que, discussão de um caso? Eles já têm um monte para discutir. Então assim, aí vai lá o grupo de apoio, aí vai a gente ficar em situação constrangedora (AP04). $\mathrm{E}$ aí a gente cria intimidade um com o outro, e ás vezes é aquela coisa. Ah! E uma vez na vida, todo mundo começou a brigar, discutir, uma confusão. Eu não gosto disso. Gosto de ser lembrada enquanto a enfermeira assistencial, não a enfermeira que cobra (AP01).

Sabemos que a prática do apoio produz efeitos nos modos dos sujeitos estarem consigo, afinal, tais práticas nunca são neutras e são produtoras de ações políticas no momento que interferem, produzem desvios e novos arranjos no curso do processo (PAVAN, TRAJANO, 2014). Assim, parece inevitável a geração de desconforto por parte do apoiador e articulador quando estes propõem a problematização do processo de trabalho em saúde. Ou seja, colocar a EPS em prática pode não ser tão agradável quanto se espera.

Nesse sentido, identificamos a contradição existente entre o emprego da EPS em ato e a possível geração de desterritorializações por meio das reflexões e análises do processo de trabalho em saúde; e o desejo de ser aceito e querido no desenvolvimento do apoio e da articulação de EPS.

Mergulhado nessa contradição, percebemos também que a existência desse(s) profissional(is) no exercício dessas funções parece gerar expectativas por parte das equipes de trabalhadores, que acreditam na possibilidade de resolução de várias (ou todas) questões que envolvem seus processos de trabalho, como podemos identificar por meio do relato a seguir:

De repente tem conflito na recepção, o usuário chega... aí as pessoas todas olham para o articulador de EPS: Aí, não está resolvendo nada esse negócio de EPS. Então parece ser uma coisa que as pessoas querem que o articulador faça mágica para que o trabalho aconteça de maneira harmônica, tranquila (APE17). 
Somada à ideia precedente, os apoiadores e articuladores também refletiram acerca da possibilidade do conflito ser um gerador de processos de imobilização e estagnação:

Mas por outro lado eu vejo que o fato do conflito também se torna um imobilizador de muitas ações (APE31).

O conflito é algo inerente a qualquer processo grupal. Ele em si não constitui em um problema. A questão se encontra em sua má resolução ou má elaboração por parte dos sujeitos que compõem o grupo, afinal, ele não deve significar paralização, mas ser capaz de gerar movimentos, desterritorializações, forças instituintes que movimentam aquilo que se encontra instituído (LAPASSADE, 1977).

É função do apoiador agenciar processos instituintes, novas invenções de fazer saúde, tendo o agenciamento enquanto "um 'entre' coletivo, que convida os instituídos a se expressarem de outra forma, sem ser a configuração dominante, provocando a convergência da heterogeneidade, das diferenças" (ROMAGNOLI, 2014, p. 49). Consiste em articular-se para o questionamento das instituições que estão colocadas nos cotidianos, fazendo junto com a equipe e não para ou por ela (PEREIRA JÚNIOR, CAMPOS, 2014).

Outro fator atrelado ao precedente e que reflete acerca da dimensão libidinal da implicação no fazer apoio e articulação de EPS, consiste na "ausência do desejo" para o desenvolvimento dessas funções, como podemos perceber por meio das seguintes falas:

Não sei se sou a pessoa mais indicada para estar nessa função (...) Ás vezes tenho muito desânimo, sabe? Não sei se é falta de vontade ou de empenho. Não sei. (AP06).

O que acontece é que a gente vai perdendo o empenho, a vontade (...) Ás vezes não me reconheço mais. É estranho. (AP12).

Porque eu estou assim, quero que se dane (...) Tenho perdido a vontade (AP13).

Aqui, cabe-nos relatar acerca do fato de que $100 \%$ dos apoiadores e articuladores das realidades estudadas foram nomeados para o exercício da função. Além disso, muitos deles nem foram consultados se gostariam ou não de ocupar esse espaço, sendo, várias vezes, informados pela Coordenadora do CDQ-III que se encontravam no exercício da função, representando o município onde trabalhavam. Ainda, são poucos os que possuem a garantia de permanência na função em detrimento dos atravessamentos já explicitados no sub-ato da dimensão organizacional da implicação profissional.

Um trabalho desenvolvido em um município de grande porte do interior do estado de São Paulo relata que $83 \%$ dos apoiadores locais ocupavam a função por meio de convite 
advindo da gestão, somado a isso, também constataram um estado de desânimo e certo imobilismo entre os apoiadores (FERNANDES, FIGUEIREDO, 2014).

Em contrapartida, também foi possível identificar a "presença do desejo" no desenvolvimento das funções de apoio e articulação de EPS.

E como a atenção básica sempre foi "a menina dos meus olhos", eu não pensei duas vezes para aceitar, então fiquei (...) eu sou apaixonado por essas políticas (PNH e PNEPS) (AP07).

Eu sempre gostei muito de trabalhar aqui, no município. Tenho até outro emprego e já falei que ia sair daqui há três meses, ia ficar no outro emprego. Eu não consegui sair daqui (AP09).

O que eu fico pensando é que o que faz continuarmos com esse "brilho nos olhos" eu acho que é um gene (...) é a vontade de mudar, só depende das pessoas (AP14).

As falas se encontram imbricadas com dimensões ideológicas dos apoiadores e articuladores, podendo ser perceptível, por exemplo, quando um deles menciona a atenção básica enquanto seu espaço preferido de atuação ou como o modelo técnico-assistencial onde este apoiador e articulador prefere desenvolver o seu trabalho. Existe uma estima, uma identificação, uma completude por este nível de atenção à saúde.

A existência do desejo para o exercício da função apoio foi também relatado em um estudo trazido por Pavan e Trajano (2014) onde concluem que os grupos de trabalho em humanização que atuavam na Freguesia do Ó, em São Paulo, se encontravam em pleno vapor, permanecendo animados, aquecidos e em constante exercício acerca da temática do apoio institucional.

Assim, a existência ou não do desejo para o desenvolvimento do apoio e da articulação de EPS é algo ainda merecedor de investimento no sentido da análise de implicação profissional, sobretudo, no desenvolvimento dessas funções.

Finalizamos aqui a apresentação do ato dos resultados da pesquisa-intervenção que compõe essa obra, procurando fazer a articulação entre a PNH e a PNEPS com a análise de implicação profissional dos apoiadores e articuladores enquanto um dispositivo desencadeador de processos de EPS. 


\section{CONSIDERAÇÕES FINAIS}

Chega o momento em que é preciso colocar um ponto final, mesmo lamentando o quanto haveria ainda para contar, para analisar (...) (L’ABBATE, 2013, p. 31).

O apoio e a articulação de EPS consistem em funções que ainda têm sido desenvolvidas com certa timidez nos municípios do DRS de Araraquara. Seus exercícios em ato, na micropolítica do trabalho vivo, parecem ser capturados por atravessamentos da ordem de forças instituídas e sedimentadas nos cotidianos dos serviços de saúde que levam à escolha pelas conhecidas em detrimento do desenvolvimento do apoio e da articulação de EPS, alguns entendimentos conceituais que inviabilizam o emprego da EPS de acordo com sua formulação inicial, a falta de organização do tempo para o exercício dessas funções, os atravessamentos transversais da gestão dos municípios e também pelas questões que envolvem o desejo na realização das funções. Colocar essas estruturas em evidência, por meio da análise de implicação profissional, demonstrou um potente dispositivo analítico e operatório para o desenvolvimento da EPS com os apoiadores e articuladores.

Foi possível identificar e analisar com os apoiadores e articuladores de EPS as relações que eles estabelecem com o apoio e com a articulação, ou seja, suas implicações profissionais, relevando e transformando suas relações com essas instituições e com outras evidenciadas por meio do processo de análise coletiva como, por exemplo, a relação estabelecida com as respectivas profissões. Permitir-se estar em processo de auto-análise e análise coletiva foi um exercício que gerou desterritorializações diversas. Consequentemente, forças instituintes foram criadas, movimentando o processo de institucionalização das políticas nacionais de Humanização e de EPS na realidade trabalhada.

A configuração de pesquisa a que nos propusemos desenvolver atuou enquanto aliada a todo processo, pois as pesquisas-intervenção, na modalidade de pesquisa Socioclínica, permite um acompanhamento longitudinal com os sujeitos, possibilitando um tempo necessário para a aproximação e sensibilização suficientes para que os processos de análise aconteçam. Afinal, permitir-se ao processo de análise de implicação é abrir-se ao desconforto, aos incômodos, às perturbações e estar disposto a lidar com essas inquietações que advém de diversas dimensões: ideológica, organizacional e libidinal.

Essas desterritorializações não somente aconteceram com os apoiadores e articuladores de EPS. A mim couberam movimentos de investidas e desinvestidas, aproximações e distanciamentos das várias instituições que me atravessaram durante o percurso de composição 
dessa obra. Lidar com as dimensões da implicação com as instituições presentes no cotidiano do trabalho em saúde, da pesquisa, da vida não é tarefa fácil, mas uma vez iniciada, parece ser incorporada ao modo de ser e estar no mundo. Utilizar desses "novos óculos" para enxergar a vida é, sobretudo, entoar fusas e semi-fusas em compassos binários, ou seja, tarefa árdua, que exige sensibilidade, mas que não são impossíveis, requerendo alguma habilidade.

Habilidade esta que fui adquirindo com o tempo e, acredito eu, que este seja um dos limites dessa tese. O desenvolvimento da habilidade de colocar em análise suas implicações e intermediar processos para que isso ocorra é algo que exige trabalho e estudo. Portanto, aos profissionais de saúde que esperam colocar a análise de implicação profissional em ato, minha indicação caminha na direção do aprendizado em ato, ou seja, na perspectiva da EPS, colocando e tentando fazê-lo na prática cotidiana, na micropolítica do trabalho vivo, respaldado pelo arcabouço teórico-metodológico que a fundamenta. Vale lembrar que o aprendizado é contínuo e nunca cessa. As aproximações são necessárias, os aprofundamentos também e a densidade do referencial teórico-metodológico trabalhado nessa possui suas particularidades, que exigem um caminhar na perspectiva contra-hegemônica de se pensar pesquisa e análise, portanto, não consiste em uma tarefa fácil.

Assim, confirmamos os pressupostos de que o emprego da análise de implicações profissional no desenvolvimento de pesquisas-intervenção e no trabalho vivo em saúde, foi capaz de gerar movimentos, reflexões, análises e, consequentemente, desterritorializações, potencializando o desenvolvimento da EPS em ato. Comprovam tais pressupostos, sobretudo, por meio de um dos princípios da Socioclínica Institucional, que procuramos aponta-lo durante todo transcorrer das análises coletivas realizadas com os apoiadores e articuladores de EPS de que transformações foram ocorrendo à medida que o trabalho foi avançando.

Nessa direção, defendemos a tese de que a análise de implicação profissional consiste em um dispositivo potente para o desencadeamento de processos de EPS, podendo ser evidenciada pelos relatos proferidos pelos apoiadores e articuladores de EPS, além do próprio processo de EPS vivenciado por mim durante esse percurso, que consistiu em um aprendizado desde o início e os deslocamentos causados durante essa trajetória foram imensuráveis, mas perceptíveis.

Em suma, apontamos para o fato da necessidade de investimentos na direção da análise da dimensão libidinal da implicação profissional no exercício do apoio e articulação de EPS, além da possibilidade de existirem outras ferramentas que possam ser utilizadas para a realização dessa análise. A música, a fotografia, a escrita, o desenho podem ser algumas delas. Então, há que se continuar na (re)invenção de novas obras, canções, ritmos, existindo múltiplas 
pautas a serem compostas tanto na perspectiva do apoio e da articulação de EPS quanto no desenvolvimento da análise de implicação em si. 


\section{REFERÊNCIAS}

AGAMBEN, G. O que é um dispositivo? In: O que é o contemporâneo? E outros ensaios. Tradução Vinícius Nicastro Honesko. Chapecó: Argos, 2009. p. 25-51.

ALMEIDA FILHO, N. Reconhecer Flexner: inquérito sobre produção de mitos na educação médica no Brasil contemporâneo. Cadernos de Saúde Pública, Rio de Janeiro, v. 26, n. 12, p. 2234-49, 2010. Disponível em: 〈http://www.scielo.br/pdf/csp/v26n12/03.pdf>. Acesso em: 25 set. 2017.

ARAGON, L. E. P. Individuar, nos individuar e individuar em nós: a transindividualidade do conhecer. Filosofia e Educação, Cidade, v. 6, n. 3, p. 187-208, 2014.

ARDOINO, J.; LOURAU, R. As pedagogias institucionais. São Carlos: RIMA, 2003.

AROUCA, A. S. S. O dilema preventivista: contribuição para a compreensão e crítica da medicina preventiva. 1975. 197 f. Tese (Doutoramento em Ciências Médicas) - Faculdade de Ciências Médicas, Universidade Estadual de Campinas, Campinas, 1975.

AUSUBEL, D. P.; NOVAK, J. D.; HANESIAN, H. Educational psychology: a cognitive view. 2. ed., New York: Holt, Rinehart e Winston, 1978. 733 p.

AZEVEDO, B. M. S.; FERIGATO, S.; SOUZA, T. P.; CARVALHO, S. R. A formação médica em debate: perspectivas a partir do encontro entre instituição de ensino e rede pública de saúde. Interface Comunicação Saúde Educação, v. 17, n. 44, p. 187-199, 2013.

Disponível em: <http://www.scielo.br/pdf/icse/v17n44/aop5412.pdf>. Acesso em: 25 set. 2017.

BARBIER, R. A pesquisa-ação na instituição educativa. Rio de Janeiro: Jorge Zahar Ed., 1985. $280 \mathrm{p}$.

BAREMBLITT, G. Compêndio de análise institucional e outras correntes: teoria e prática. 6 ed. Belo Horizonte: Record, 2012. 214 p.

BARROS, M. E. B.; GUEDES, C. R.; ROZA, M. M. R. O apoio institucional como método de análise-intervenção no âmbito das políticas públicas de saúde: a experiência em um hospital geral. Ciência \& Saúde Coletiva, v. 16, n. 12, p. 4803-4814, 2011. Disponível em: < http://www.scielo.br/pdf/csc/v16n12/29.pdf>. Acesso em: 25 set. 2017.

BATISTA, K. B. C.; GONÇALVES, O. S. J. Formação dos profissionais de saúde para o SUS: significado e cuidado. Saúde e Sociedade, v. 20, n. 4, p. 884-899, 2011. Disponível em: <http://www.scielo.br/pdf/sausoc/v20n4/07.pdf>. Acesso em: 25 set. 2017.

BELLEGARDE, P. L'instituant contre l'institué (1969). In: LAMIHI, A.; MONCEAU, G. Instituition et implication. Paris: Syllepse, 2002. p. 53-60.

BESSAOUD-ALONSO, P. Collaborations et tensions entre parentes et professionnels. Un dispositif d'élaboration d'une parole audible. In: MONCEAU, G. (Org.). Enquêter ou 
intervenir? Effets de la recherche socio-clinique. 1ed. Nîmes: Champ social éditions, 2017. p. 20-29.

BICHUETTI, J. Utopia ativa. Disponível em: <http://entre-nuentre.blogspot.com.br/2011/01/utopia-ativa.html>. Acesso em: 27 set. 2017.

BRASIL. Ministério da Saúde. Coordenação-Geral de Desenvolvimento de Recursos Humanos para o SUS. A questão dos recursos humanos nas Conferências Nacionais de Saúde (1941-1992). Cadernos RH Saúde, Brasília, ano 1, v. 1, n. 1, 1993. Disponível em: <http://bvsms.saude.gov.br/bvs/periodicos/crhsv1n1.pdf>. Acesso em: 13 fev. 2017.

. Ministério da Saúde. Coordenação-Geral de Desenvolvimento de Recursos Humanos para o SUS. II Conferência Nacional de Recursos Humanos para a Saúde: Relatório Final. Cadernos RH Saúde, Brasília, v. 3, n. 1, 1994. Disponível em: 〈http://bvsms.saude.gov.br/bvs/periodicos/crhsv2n1.pdf>. Acesso em: 13 fev. 2017.

. Ministério da Saúde. Manual do Programa Nacional de Humanização da Assistência Hospitalar. Brasília, DF: Ministério da Saúde, 2001.

Ministério da Saúde. Caminhos para a mudança da formação e desenvolvimento dos profissionais de saúde: diretrizes para a ação política para assegurar Educação Permanente no SUS, Brasília, DF: Departamento de Gestão da Educação em Saúde, 2003a.

Ministério da Saúde. HumanizaSUS: Política Nacional de Humanização.

Secretaria-Executiva. Núcleo Técnico da Política Nacional de Humanização. Brasília: 2003b.

Ministério da Saúde. Departamento de Gestão em Educação na Saúde. Política Nacional de Educação Permanente em Saúde. Portaria no 198/GM/MS de 13 de fevereiro de 2004. Brasília, 2004.

Ministério da Saúde. Secretaria de Atenção à Saúde. Política Nacional de

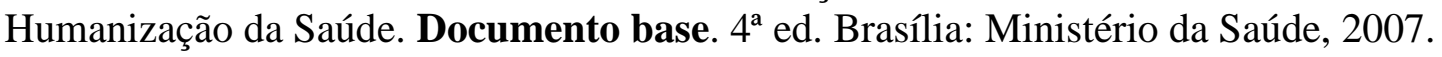

Ministério da Saúde. Secretaria de Atenção à Saúde. Núcleo Técnico da Política Nacional de Humanização. HumanizaSUS: Documento base para gestores e trabalhadores do SUS. $4^{a}$ ed. Brasília: Ministério da Saúde, 2008.

Ministério da Saúde. Secretaria de Atenção à Saúde. Política Nacional de Humanização. Formação e intervenção. Brasília: Ministério da Saúde, 2010.

Ministério da Saúde. Secretaria de Atenção à Saúde. Política Nacional de Humanização da Saúde. Cartilha HumanizaSUS. $1^{\mathrm{a}}$ ed. $1^{\mathrm{a}}$ reimpressão. Brasília: Ministério da Saúde, 2013.

Ministério do Planejamento, Orçamento e Gestão. Instituto Brasileiro de Geografia e Estatística. Contagem Populacional. Disponível em:

<http://www.ibge.gov.br/home/http://www.ibge.gov.br/home/>. Acesso em: 04 jan. 2017. 
CAMPOS, G. W. S. Saúde pública e saúde coletiva: campo e núcleo de saberes e práticas.

Ciência \& Saúde Coletiva. v. 5, n. 2, p. 219-230, 2000. Disponível em:

<http://www.scielo.br/pdf/csc/v5n2/7093.pdf>. Acesso em: 25 set. 2017.

CAMPOS, G. W. S. Um método para análise e co-gestão de coletivos: a constituição do sujeito, a produção de valor de uso e a democracia em instituições: o método da roda. 3 ed. São Paulo: Hucitec, 2007.

CAMPOS, G. W. S.; CASTRO, C. P.; FERNANDES, J. A.; ANÉAS, T. V. Investigação sobre cogestão, apoio institucional e apoio matricial no SUS. São Paulo: Hucitec, 2017.

CARVALHO, Y. M.; CECCIM, R. B. Formação e educação em saúde: aprendizados com a saúde coletiva. In: CAMPOS, G. W. S.; BONFIM, J. R. A.; MINAYO, M. C. S.;

AKERMAN, M.; DRUMOND JÚNIOR, M.; CARVALHO, Y. M. (Org.). Tratado de saúde coletiva. 2 ed. São Paulo: Hucitec, 2016. p. 137-170.

CASTRO, C. P.; ANÉAS, T. V. O apoio paideia e a gestão da pesquisa: trilhando caminhos. In: CAMPOS, G. W. S.; CASTRO, C. P.; FERNANDES, J. A.; ANÉAS, T. V. (Org.). Investigação sobre cogestão apoio institucional e apoio matricial no SUS. São Paulo: Hucitec, 2017. p. 25-39.

CASTRO, C. P.; CAMPOS, G. W. S. Apoio institucional paideia como estratégia para educação permanente em saúde. Trabalho, Educação e Saúde, Rio de Janeiro, v. 12, n. 1, p. 29-50, 2014. Disponível em: 〈http://www.scielo.br/pdf/tes/v12n1/03.pdf>. Acesso em 25 set. 2017.

CECCIM, R. B. Educação permanente em saúde: desafio ambicioso e necessário. Interface Comunicação Saúde Educação, Botucatu, v. 9, n. 16, p. 161-177, 2005a. Disponível em: <http://www.scielo.br/pdf/tes/v12n1/03.pdf>. Acesso em: 25 set. 2017.

CECCIM, R. B. Educação permanente em saúde: descentralização e disseminação de capacidade pedagógica na saúde. Ciência \& Saúde Coletiva, Rio de Janeiro, v. 10, n. 4, p. 975-986, 2005b. Disponível em: 〈http://www.scielo.br/pdf/tes/v12n1/03.pdf >. Acesso em: 25 set. 2017.

CECCIM, R. B.; CARVALHO, Y. M. Ensino da saúde como projeto da integralidade: a educação dos profissionais da saúde no SUS. In: PINHEIRO, R.; CECCIM, R. B.; MATTOS, R. A. (Orgs.). Ensinar saúde: a integralidade e o SUS nos cursos de graduação na área da saúde. 2 ed. Rio de Janeiro: IMS/UERJ, CEPESQ, ABRASCO, 2006. p. 69-92.

CECCIM, R. B.; FERLA, A. A. Educação permanente em saúde. In: Escola Politécnica de Saúde Joaquim Venâncio (Org.). Dicionário da educação profissional em saúde. Rio de Janeiro: EPSJV/Fiocruz, 2006, p. 107-112.

CECCIM, R. B.; FEUERWERKER, L. C. M. O quadrilátero da formação para a área da saúde: ensino, gestão, atenção e controle social. Physis, Rio de Janeiro, v. 14, n. 1, p. 41-65, 2004. Disponível em: 〈http://www.scielo.br/pdf/physis/v14n1/v14n1a04.pdf>. Acesso em: 25 set. 2017. 
CONTERNO, S. F. R. Pressupostos pedagógicos das atuais propostas de formação superior em saúde no Brasil: origens históricas e fundamentos teóricos. 2013. 262 f. Tese (Doutorado em Educação) - Programa de Pós-graduação em Educação, Universidade Federal de São Carlos, São Carlos, 2013.

CONTERNO, S. F. R.; LOPES, R. E. Pressupostos pedagógicos das atuais propostas de formação superior em saúde no Brasil: origens históricas e fundamentos teóricos. Avaliação, Campinas, v. 21, n. 3, p. 993-1016, 2016. Disponível em:

<http://www.scielo.br/pdf/aval/v21n3/1982-5765-aval-21-03-00993.pdf>. Acesso em: 25 set. 2017.

COSTA, M. V.; PATRÍCIO, K.P.; CÂMARA, A. M. C. S.; AZEVEDO, G. D.; BATISTA, S. H. S. S. Pró-Saúde e PET-Saúde como espaços de educação interprofissional. Interface, Rio de Janeiro, v. 19, Suplemento 1, 2015, p. 709-20. Disponível em: <

http://www.scielo.br/pdf/icse/v19s1/1807-5762-icse-19-s1-0709.pdf>. Acesso em: 27 set. 2017.

COSTA, M. V.; BORGES, F. A. O Pró-PET-Saúde frente aos desafios do processo de formação profissional em saúde. Interface, Botucatu, v. 19, Suplemento 1, p. 753-63, 2015. Disponível em: 〈http://www.scielo.br/pdf/icse/v19s1/1807-5762-icse-19-s1-0753.pdf〉. Acesso em: 27 set. 2017.

DIEBOLT, É. Léonie chaptal (1873-1937), architecte de la profession infirmière. Recherche em soins infirmiers, v. 2, n. 109, p. 93-107, 2012. Disponível em: <https://www.cairn.info/revue-recherche-en-soins-infirmiers-2012-2-page-93.htm>. Acesso em: 25 set. 2017.

DOBBIES, D. V.; L'ABBATE, S. A resistência como analisador da saúde mental em Campinas (SP): contribuições da análise institucional. Saúde Debate, Rio de Janeiro, v. 40, n. 110, p. 120-133, 2016. Disponível em: <http://www.scielo.br/pdf/sdeb/v40n110/0103-1104sdeb-40-110-0120.pdf>. Acesso em: Acesso em: 25 set. 2017.

FERNANDES, J. A.; FIGUEIREDO, M. D. Apoio institucional e cogestão: uma reflexão sobre o trabalho dos apoiadores do SUS Campinas. Physis, Rio de Janeiro, v. 25, n. 1, p. 287 306, 2015. Disponível em: <http://www.scielo.br/pdf/physis/v25n1/0103-7331-physis-25-0100287.pdf>. Acesso em: 25 set. 2017.

FERREIRA, I. D. F.; LAGES, I. Diretrizes curriculares para a formação de profissionais de saúde: competências ou práxis? Trab. Educ. Saúde, Rio de Janeiro, v. 11, n. 2, p. 319-38, 2013. Disponível em: <http://www.scielo.br/pdf/tes/v11n2/a04v11n2.pdf>. Acesso em: 25 set. 2017.

FEUERWERKER, L. M. Mudanças na educação médica e residência médica no Brasil. São Paulo: Hucitec, 1998. 190 p.

FEUERWERKER, L. C. M. Micropolítica e saúde: produção do cuidado, gestão e formação. Porto Alegre: Rede Unida, 2014. 176 p.

FORTUNA, C. Cuidando de quem cuida: notas cartográficas de uma intervenção institucional na montagem de uma equipe de saúde como engenhoca mutante para a produção de vida. 2003. 197 f. Tese (Doutorado em Enfermagem em Saúde Pública) - Departamento 
de Enfermagem materno Infantil e Saúde Pública, Universidade de São Paulo, Ribeirão Preto, 2003.

FORTUNA, C. M.; MESQUITA, L. P.; MATUMOTO, S.; MONCEAU, GILLES. A análise de implicação de pesquisadores em uma pesquisa-intervenção na Rede Cegonha: ferramenta da análise institucional. Cadernos de Saúde Pública, Rio de Janeiro, v. 32, n. 9, p. e00117615, 2016. Disponível em: < http://www.scielo.br/pdf/csp/v32n9/1678-4464-csp-32-09e00117615.pdf>. Acesso em: 27 set. 2017.

FOUCAULT, M. Microfísica do poder. São Paulo: Graal, 1979. 174 p.

FOUCAULT, M. Vigiar e punir. 20 ed. Petrópolis: Vozes, 1999. 262 p.

FURTER, P. O planejador e a educação permanente. In: Fundamentos do planejamento educacional. Instituto Internacional de Planejamento Educacional, UNESCO, 1977. p. 76-99.

FURTER, P. Educação permanente e desenvolvimento cultural. Petrópolis: Vozes, 1974. $221 \mathrm{p}$.

FREIRE, M. O que é um grupo?. In: GROSSI, E.; BORDIN, J. Paixão de aprender. Petrópolis: Vozes, 1993. p. 59-68.

FREIRE, P. Pedagogia do oprimido. 47 ed. Rio de Janeiro: Paz e Terra, 2008. 184 p.

GARCIA, L. B. R. A ideologia e o poder disciplinar como formas de dominação.

Trans/Form/Ação. n. 11, p. 53-59, 1988. Disponível em:

<http://www.scielo.br/pdf/trans/v11/v11a07.pdf>. Acesso em: 27 set. 2017.

GUATARRI, F. Psicanálise e transversalidade. Aparecida: Ideias \& Letras, 2004. 366 p.

GUATARRI, F.; ROLNIK, S. Micropolítica: cartografias do desejo. 4 ed. Petrópolis: Vozes, 1996. p. 232-264.

JESUS, A. F.; PEZZATO, L. M.; ABRAHÃO, A. L. O uso do diário como ferramenta estratégica da análise institucional para abordar o cotidiano do profissional de saúde: o caso do dom queixote. In: L’ABBATE, S.; MOURÃO, L. C.; PEZZATO, L. M. Análise Institucional \& Saúde Coletiva. São Paulo: Hucitec, 2013. p. 206-235.

KEMP, A.; EDLER, F. C. A reforma médica no Brasil e nos Estados Unidos: uma comparação entre duas retóricas. História, Ciências, Saúde, Rio de Janeiro, v. 11, n. 3, p. 569-585, 2004. Disponível em: < http://www.scielo.br/pdf/hcsm/v11n3/02.pdf>. Acesso em: 27 set. 2017.

L'ABBATE, S. A análise institucional e a saúde coletiva. Ciência \& Saúde Coletiva, Rio de Janeiro, v. 8, n. 1, p. 265-274, 2003. Disponível em:

<http://www.scielo.br/pdf/csc/v8n1/a19v08n1.pdf>. Acesso em: 27 set. 2017.

L'ABBATE, S. O analisador dinheiro em um trabalho de grupo realizado num hospital universitário em Campinas, São Paulo: revelando e desvelando as contradições institucionais. 
In: RODRIGUES, H. B. C.; ALTOÉ, S. Saúde e Loucura no 8. São Paulo: Hucitec, 2004. p. 79-99.

L'ABBATE, S. Análise institucional e intervenção: breve referência à gênese social e histórica de uma articulação e sua aplicação na saúde coletiva. Mnemosine, Rio de Janeiro, v. 8, n. 1, p. 194-219, 2012. Disponível em:

<http://www.mnemosine.com.br/ojs/index.php/mnemosine/article/view/247/pdf 232>. Acesso em: 27 set. 2017.

LAMBERT, J. B. Tendências de mudanças na formação médica no Brasil: tipologia das escolas. 1. ed. São Paulo: Hucitec, 2002. 283 p.

LAPASSADE, G. L'analyseur et l'analyste. Paris: Gauthier-Villars, 1971. 205 p.

LAROUSSE. Dicionário online. Disponível em:

<http://www.larousse.fr/dictionnaires/francais>. Acesso em: 05 jan. 2017.

LEMOS, C. L. S. A concepção de educação da política nacional de educação permanente em saúde. 2010. 157f. Tese (Doutorado em Educação) - Programa de Pós-Graduação em Educação FE/ UFG, Universidade Federal de Goiás, Goiânia, 2010.

LINS, A. M.; CECÍLIO, L. C. O. O programa UNI no Brasil: uma avaliação da coerência no seu processo de formulação e implementação. Interface, Botucatu, v. 2, n. 3, p. 87-106, 1998. Disponível em: 〈http://www.scielo.br/pdf/icse/v2n3/07.pdf〉. Acesso em: 05 jan. 2017.

LOURAU, R. René Lourau na UERJ: Análise institucional e práticas de pesquisa. Rio de Janeiro: NAPE/UERJ, 1993. 119 p. $176 \mathrm{p}$.

Interventions socianalytiques: les analyseurs de l'église. Paris: Anthropos, 1996.

Implication transduction. Paris: Anthropos, 1997a. 9-13 p.

La clé des champs. Paris: Anthropos, 1997b. 112 p.

Implicação e sobreimplicação. In: ALTOÉ, S. (Org.) René Lourau: analista institucional em tempo integral. São Paulo: Hucitec, 2004a. p. 186-198.

Objeto e método da Análise Institucional. In: ALTOÉ, S. (Org.) René Lourau: analista institucional em tempo integral. São Paulo: Hucitec, 2004b. p. 66-86.

A análise institucional. 3. ed. Petrópolis: Vozes, 2014. 328 p.

MACHADO, S. S.; MATTOS, R. J. B. Apoio institucional na atenção básica: a experiência no município de Salvador-BA. Rev. Bahiana de Saúde Pública, v. 39, n. 1, p. 139-149, 2015. Disponível em: 〈http://rbsp.sesab.ba.gov.br/index.php/rbsp/article/view/760/1225>. Acesso em: 05 jan. 2017.

MASCARENHAS, N. B.; MELO, C. M. M.; SILVA, L. A. Gênese do trabalho profissional da enfermeira no Brasil (1920-1925). Escola Anna Nery, v. 20, n. 2, p. 220-7, 2016. 
Disponível em: 〈http://www.scielo.br/pdf/ean/v20n2/1414-8145-ean-20-02-0220.pdf >. Acesso em: 05 jan. 2017.

MARTIN, C. S. Que disent les élèves de CLIS 1 de leur(s) place(s) dans l'école ? Un empan liminal. 2014. 475 f. Tese (Doutorado em Ciências da Educação) - Ecole Doctorale Droit et Sciences Humaines ED 284, Universidade de Cergy Pontoise, Gennevilliers, 2015.

MERHY, E. E. O ato de cuidar: a alma dos serviços de saúde. São Paulo: CINAEM; 1999. (Coletânea da CINAEM - Oficina A Gestão de Escolas Médicas).

MERHY, E. E. Em busca do tempo perdido: a micropolítica do trabalho vivo em saúde. In: MERHY, E. E.; ONOCKO, R. Agir em saúde, um desafio para o público. 3 ed. São Paulo: Hucitec, 2007. p. 71-112.

MICHAELIS. Moderno Dicionário da Língua Portuguesa. Disponível em: <http://michaelis.uol.com.br/moderno-portugues/>. Acesso em: 05 jan. 2017.

MINAYO, M. C. S. Estrutura e sujeito, determinismo e protagonismo histórico: uma reflexão sobre a práxis da saúde coletiva. Ciência \& Saúde Coletiva, Rio de Janeiro, v. 6, p. 1, p. 719, 2001. Disponível em: 〈http://www.scielo.br/pdf/csc/v6n1/7022.pdf〉. Acesso em: 26 set. 2017.

O desafio do conhecimento: pesquisa qualitativa em saúde. 12. ed. São Paulo: Hucitec, 2010. 408 p.

MISHIMA, S. M.; AIUB, A. C.; RIGATO, A. F. G.; FORTUNA, C. M.; MATUMOTO, S.; OGATA, M. N.; SILVA, M. V.; NOGUEIRA, A. C. Perspectivas dos gestores de uma região do estado de São Paulo sobre educação permanente em saúde. Rev Esc Enferm USP, São Paulo, v. 49, n. 4, p. 665-673, 2015. Disponível em: < https://www.revistas.usp.br/reeusp/article/view/103404/101878>. Acesso em: 26 set. 2017.

MISHIMA, S. A gerência de serviços de atenção primária à saúde como instrumento para a reorganização da assistência à saúde - o caso do Programa de Saúde da Família. 2003. 166 p. Tese (Livre-docência) - Departamento de Enfermagem Materno-Infantil e Saúde Pública, Universidade de São Paulo, Ribeirão Preto, 2003.

MONCEAU, G. Entrevista com Gilles Monceau. Fractal Rev. de Psic., Rio de Janeiro, v. 20, n. 1, p. 309-318, 2008a. Disponível em:

<http://www.scielo.br/scielo.php?script=sci arttext\&pid=S1984-02922008000100027>. Acesso em: 26 set. 2017.

Implicação, sobreimplicação e implicação profissional. Fractal Rev. de Psic, Rio de Janeiro, v. 20, n. 1, p. 19-26, 2008b. Disponível em:

<http://www.scielo.br/pdf/fractal/v20n1/a07v20n1.pdf>. Acesso em: 26 set. 2017.

L'analyse institutionnelle des pratiques: une socio-clinique des tourments instittutionnels au Brésil et en France. Paris: L'Harmattan, 2012. 212 p. 
A Socioclínica institucional para pesquisas em educação e em saúde. In:

L’ABBATE, S.; MOURÃO, L. C.; PEZZATO, L. M. Análise Institucional \& Saúde Coletiva. São Paulo: Hucitec, 2013. p. 91-103.

MONTANHA, D.; PEDUZZI, M. Educação permanente em enfermagem: levantamento de necessidades e resultados esperados segundo a concepção dos trabalhadores. Rev. Esc.

Enferm. USP, São Paulo, v. 44, n. 3, p. 597-604, 2010. Disponível em:

<http://www.scielo.br/pdf/reeusp/v44n3/07.pdf>. Acesso em: 26 set. 2017.

MOURA, R. H.; LUZIO, C. A. O apoio institucional como uma das faces da função apoio no Núcleo de Apoio à Saúde da Família (NASF): para além das diretrizes. Interface

Comunicação Saúde Educação, Botucatu, v. 18, n. 1, p. 973-986, 2014. Disponível em: <http://www.scielo.br/pdf/icse/v18s1/1807-5762-icse-1807-576220130333.pdf>. Acesso em: 26 set. 2017.

MOURÃO, L. C.; SILVA, A. L. A.; SPAGNOL, C. A.; MALAMAN, L. B. Analyser l'implication des professionels em santé collective em accompagnant les equipes. Commento la découberte des implications transforme la pratique collective? In: MONCEAU, G.

L'analyse institutionnelle des pratiques. Paris: Harmattan, 2013. p. 313-360.

OFICINA SANITÁRIA PANAMERICANA. Seminarios sobre la enseñanza de medicina preventiva. Washington D.C.: Publicações Científicas no 28. Mar. 1957. Disponível em: <http://hist.library.paho.org/English/SPUB/40174.pdf>. Acesso em: 02 fev. 2017.

OLIVEIRA, G. N. Devir apoiador: uma cartografia da função apoio. 2011. 175 f. Tese (Doutorado em Saúde Coletiva) - Faculdade de Ciências Médicas, Universidade Estadual de Campinas, Campinas, 2011.

ORGANIZACIÓN PANAMERICANA DE LA SALUD. Educación permanente de personal de salud en la región de las américas. Fascículo I: Propuesta de reorientación. Fundamentos. Serie de desarrollo de recursos humanos, $\mathrm{n}^{\circ} .78,1988$.

ORGANIZACIÓN PANAMERICANA DE LA SALUD. II Plan Decenal de Salud para las Americas: Informe final de la III Reunión Especial de Ministros de Salud de las Américas. OPAS/OMS: Washington, D.C. Enero, 1973. Disponível em:

<http://hist.library.paho.org/English/OD/34900.pdf>. Acesso em: 02 fev. 2017.

ORGANIZAÇÃO DAS NAÇÕES UNIDAS PARA A EDUCAÇÃO, A CIÊNCIA E A CULTURA. 15 Conferência 1968. Disponível em: <http://unesdoc.unesco.org/images/0016/001601/160197eb.pdf>. Acesso em: 16 mai. 2017.

PADILHA, M. I. C. S.; MANCIA, J. R. Florence Nightingale e as irmãs de caridade: revisitando a história. Rev. Bras. Enfem., Brasília, v. 58, n. 6, p. 723-6, 2005. Disponível em: < http://www.scielo.br/pdf/reben/v58n6/a18v58n6.pdf $>$. Acesso em: 16 mai. 2017.

PAGLIOSA, F. L.; DA ROS, M. A. O relatório flexner: para o bem e para o mal. Rev. Bra. Educ. Med., Rio de Janeiro, v. 32, n. 4, p. 492-499, 2008. Disponível em: < http://www.scielo.br/pdf/rbem/v32n4/v32n4a12.pdf>. Acesso em: 16 mai. 2017. 
PAILLÉ, P.; MUCCHIELLI, A. L'analyse qualitative en sciences humaines et sociales. 3 ed. Paris: Armanda Colin, 2012. 423 p.

PAIM, J. S.; ALMEIDA FILHO, N. Saúde coletiva: uma "nova saúde pública" ou um campo aberto a novos paradigmas? Revista de Saúde Pública, São Paulo, v. 32, n. 4, p. 299-316, 1998. Disponível em: < http://www.scielo.br/pdf/rsp/v32n4/a2593.pdf>. Acesso em: 16 mai. 2017.

PASCHE, D. F.; PASSOS, E.; HENNINGTON, E. A. Cinco anos da Política Nacional de Humanização: trajetória de uma política pública. Ciência \& Saúde Coletiva, Rio de Janeiro, v. 16, n. 11, p. 4541-4548, 2011. Disponível em: <

http://www.scielo.br/pdf/csc/v16n11/a27v16n11.pdf>. Acesso em: 16 mai. 2017.

PASSOS, E.; CARVALHO, Y. M. A formação para o SUS abrindo caminhos para a produção do comum. Saúde e Sociedade, São Paulo, v. 24, Suplemento I, p. 92-101, 2015. Disponível em: < http://www.scielo.br/pdf/sausoc/v24s1/0104-1290-sausoc-24-s1-00092.pdf> Acesso em: 16 mai. 2017.

PAULINO, V. C. P.; BEZERRA, A. L. Q.; BRANQUINHO, N. C. S. S.; PARANAGUÁ, T. T. B. Ações de educação permanente no contexto da estratégia saúde da família. Rev.

Enferm. UERJ, Rio de Janeiro, v. 20, n. 3, p. 312-316, 2012. Disponível em: < http://www.epublicacoes.ueri.br/index.php/enfermagemueri/article/view/687/2885>. Acesso em: 16 mai. 2017.

PAULON, S. M. A análise de implicação como ferramenta na pesquisa-intervenção. Psicologia \& Sociedade, Belo Horizonte, v. 17, n. 3, p. 18-25, 2005. Disponível em: < http://www.scielo.br/pdf/psoc/v17n3/a03v17n3>. Acesso em: 16 mai. 2017.

PAULON, S. M.; ROMAGNOLI, R. C. Pesquisa-intervenção e cartografia: melindres e meandros metodológicos. Estudos e Pesquisa em Psicologia, Rio de Janeiro, v. 10, n. 1, p. 85-102, 2010. Disponível em: <http://www.epublicacoes.ueri.br/index.php/revispsi/article/view/9019/7455>. Acesso em: 16 mai. 2017.

PAVAN, C.; TRAJANO, A. R. C. Apoio institucional e a experiência da Política Nacional de Humanização (PNH) na Freguesia do Ó, Brasilândia, São Paulo, Brasil. Interface, Botucatu, v. 18, Supl I, p. 1027-1040, 2014. Disponível em: < http://www.scielo.br/pdf/icse/v18s1/18075762-icse-18-1-1027.pdf >. Acesso em: 16 mai. 2017.

PEDUZZI, M.; NORMAN, I. J.; GERMANI, A. C. C. G.; SILVA, J. A. M.; SOUZA, G. C. Educação interprofissional: formação de profissionais de saúde para o trabalho em equipe com foco nos usuários. Rev. Esc. Enferm. USP, São Paulo, v. 47, n. 4, p. 977-83, 2013. Disponível em: 〈http://www.scielo.br/pdf/reeusp/v47n4/0080-6234-reeusp-47-4-0977.pdf> . Acesso em: 27 set. 2017.

PEDUZZI, M.; CARVALHO, B. G.; MANDÚ, E. N. T.; SOUZA, G. C.; SILVA, J. A. M. Trabalho em equipe na perspectiva da gerência de serviços de saúde: instrumentos para a construção da prática interprofissional. Physis, Rio de Janeiro, v. 21, n. 2, p. 629-646, 2011. Disponível em: 〈http://www.scielo.br/pdf/physis/v21n2/a15v21n2.pdf>. Acesso em: 27 set. 2017. 
PENIDO, C. A análise da implicação como dispositivo de transformação do processo de trabalho. Rev. Interinst. de Psic., Belo Horizonte, v. 8, n. 2, p. 248-257, 2015. Disponível em: < www.fafich.ufmg.br/gerais/index.php/gerais/article/download/558/383>. Acesso em: 27 set. 2017.

PEREIRA, S. M.; PEDRO, J. M. Saúde e história segundo Luiz Antônio de Castro Santos e Lina Faria. História, Ciências, Saúde, Manguinhos, v. 20, n. 2, p. 712-16, 2013. Disponível em: < http://www.scielo.br/pdf/hcsm/v20n2/0104-5970-hcsm-20-02-00712.pdf>. Acesso em: 27 set. 2017.

PEREIRA JÚNIOR, N.; CAMPOS, G. W. S. O apoio institucional no Sistema Único de Saúde (SUS): os dilemas da integração interfederativa e da cogestão. Interface, Botucatu, v. 18, Supl I, p. 895-908, 2014. Disponível em: <http://www.scielo.br/pdf/icse/v18s1/1807-5762icse-18-1-0895.pdf>. Acesso em: 27 set. 2017.

PERES, C.; SILVA, R. F.; BARBA, P. C. S. D. Desafios e potencialidades do processo de educação permanente em saúde. Trabalho Educação Saúde, Rio de Janeiro, v. 14, n. 3, p. 783-801, 2016. Disponível em: < http://www.scielo.br/pdf/tes/v14n3/1981-7746-tes-1981-7746sol00016.pdf>. Acesso em: 27 set. 2017.

PEZZATO, L. M.; L’ABBATE, S. O uso de diários como ferramenta de intervenção da análise institucional: potencializando reflexões no cotidiano da saúde bucal coletiva. Physis, Rio de Janeiro, v. 21, n. 4, p. 1297-1314, 2011. Disponível em: < http://www.scielo.br/pdf/physis/v21n4/a07v21n4.pdf>.Acesso em: 27 set. 2017.

PEZZATO, L. M.; PRADO, G. V. T. Pesquisa-ação e pesquisa-intervenção: aproximações, distanciamentos, conjugações. In: L’ABBATE, S.; MOURÃO, L. C.; PEZZATO, L. M. (Org.) Análise Institucional \& Saúde Coletiva. São Paulo: Hucitec, 2013. p. 149-179.

PINTO, H. A.; FERLA, A. A. Formulação e implementação de políticas como pedagogias para a gestão: um ensaio a partir de três casos do sistema único de saúde. Saúde em Redes, Juiz de Fora, v. 1, n. 1, p. 81-94, 2015. Disponível em:

<http://revista.redeunida.org.br/ojs/index.php/rede-unida/article/view/321/22>. Acesso em: 27 set. 2017.

ROCHA, D.; DEUSDARÁ, B. Contribuições da análise institucional para uma abordagem das práticas linguageiras: a noção de implicação na pesquisa de campo. Cadernos de Letras da UFF, Rio de Janeiro, v. 40, p. 47-73, 2010. Disponível em: < http://www.uff.br/cadernosdeletrasuff/40/artigo2.pdf>. Acesso em: 27 set. 2017.

RODRIGUES, H. B. C. As subjetividades em revolta: institucionalismo francês e novas análises. Dissertação (Mestrado) -Instituto de Medicina Social/ IMS-UERJ, Rio de Janeiro, 1994.

ROMAGNOLI, R. C. O conceito de implicação e a pesquisa-intervenção institucionalista. Psicologia \& Sociedade, Belo Horizonte, v. 26, n. 1, p. 44-52, 2014. Disponível em: < http://www.scielo.br/pdf/psoc/v26n1/06.pdf>. Acesso em: 27 set. 2017.

ROUGERIE, C. L'accueil: un analiseur des implications professionnelles dans le travail social. 2015. 363 f. Tese (Doutorado em Ciências da Educação) - Ecole Doctorale Droit et 
ROUTHIER-BAUTZER, É. Formation des soignants en France : la difficile émergence de nouveaux modèles. Les tribunes de la santé, France, n. 36, p. 83-88, 2012. Disponível em: < https://www.cairn.info/revue-les-tribunes-de-la-sante-2012-3-page-83.htm>. Acesso em: 27 set. 2017.

SALDANHA, O. M. F. L.; PEREIRA, A. L. B.; MEDEIROS, C. R. G.; DHEIN, G.; KOETZ, L. C. E.; SCHWERTNER, S. F.; CECCIM, R. B. Clínica-escola: apoio institucional inovador às práticas de gestão e atenção na saúde como parte da integração ensino-serviço. Interface, Botucatu, v. 18, Suplemento I, p. 1053-1062, 2014. Disponível em: < http://www.scielo.br/pdf/icse/v18s1/1807-576-icse-1807-576220130446.pdf>. Acesso em: 27 set. 2017.

SALGADO, A. C. S.; PENA, R. S.; CALDEIRA, L. W. D. Apoio institucional e militância no Sistema Único de Saúde (SUS): refletindo os desafios da mobilização dos sujeitos na produção de saúde. Interface, Botucatu, v. 18, Suplemento I, p. 909-918, 2014. Disponível em: 〈http://www.scielo.br/pdf/icse/v18s1/1807-576-icse-1807-576220130221.pdf〉. Acesso em: 27 set. 2017.

SANTANA, F. R. Promoção da saúde e prevenção de doenças na formação profissional do enfermeiro: pesquisa socioclínica no Brasil e na França. 2016. 341f. Tese (Doutorado Cotutela em Ciências da Saúde e Ciências da Educação) - Escola de Enfermagem de Ribeirão Preto, Universidade de São Paulo, Universidade de Cergy Pontoise, Gennevilliers, 2016.

SÃO PAULO. Plano de ação regional da rede de urgência e emergência RRAS 13. Araraquara, 2012.

Mapa da saúde da região central do DRSIII - Araraquara. Departamento Regional de Saúde III. Araraquara, 2013.

Plano de atenção à saúde das pessoas com doenças crônicas: linha de cuidado oncológica. Araraquara, 2016.

SCHOTT, M. Educação permanente em saúde: implementação da política no estado de São Paulo. 2013. 302p. Tese (Doutorado em Educação) - Faculdade de Educação, Universidade Estadual de Campinas, Campinas, 2013.

SEVERO, A. K. S.; L’ABBATE, S.; CAMPOS, R. T. O. A supervisão clínico-institucional como dispositivo de mudanças na gestão do trabalho em saúde mental. Interface, Botucatu, v. 18, n. 50, p. 545-556, 2014. Disponível em: < http://www.scielo.br/pdf/icse/v18n50/1807-5762icse-1807-576220130520.pdf>. Acesso em: 27 set. 2017.

SILVA, F. H.; BARROS, M. E. B.; MARTINS, C. P. Experimentações e reflexões sobre o apoio institucional em saúde: trabalho a partir do HumanizaSUS. Interface, v. 19, n. 55, p. 1157-1168, 2015. Disponível em: <http://www.scielo.br/pdf/icse/v19n55/1807-5762-icse-1807576220130280.pdf>. Acesso em: 27 set. 2017.

SILVA, J. A. M.; PEDUZZI, M. Educação no Trabalho na Atenção Primária à Saúde: interfaces entre a educação permanente em saúde e o agir comunicativo. Saúde Sociedade. São Paulo, v.20, n.4, p.1018-1032, 2011. Disponível em: <http://www.scielo.br/pdf/sausoc/v20n4/18.pdf>. Acesso em: 27 set. 2017. 
TEDESCO, S. H.; SADE, C.; CALIMAN, L. V. A entrevista na pesquisa cartográfica: a experiência do dizer. Fractal, v. 25, n. 2, p. 299-322, 2013. Disponível em: < http://www.scielo.br/pdf/fractal/v25n2/06.pdf>. Acesso em: 27 set. 2017.

VASCONCELOS, M. F. F.; NOCOLOTTI, C. A.; SILVA, J. F.; PEREIRA, S. M. L. R. Entre políticas (EPS - Educação Permanente em Saúde e PNH - Política Nacional de Humanização): por um modo de formar no/para o Sistema Único de Saúde (SUS). Interface, v. 20, n. 59, p. 981-991, 2016. Disponível em: < http://www.scielo.br/pdf/icse/v20n59/18075762-icse-1807-576220150707.pdf>.

Acesso em: 27 set. 2017.

YAHN, P. I. F. C.; YASUI, S. O apoiador caipira: o desafio/arte de articular redes regionais a partir de territórios/desejos singulares. Interface, v. 18, Suplemento I, p. 871-884, 2014. Disponível em: < http://www.scielo.br/pdf/icse/v18s1/1807-5762-icse-18-1-0871.pdf>. Acesso em: 27 set. 2017. 


\section{APÊNDICES}

\section{APÊNDICE 1}

Distribuição dos Apoiadores de Humanização segundo os respectivos municípios que compõem o DRS de Araraquara

\begin{tabular}{l|l}
\hline \multicolumn{1}{c|}{ Município } & \multicolumn{1}{c}{ Nome } \\
\hline Américo Brasiliense & Juliana de Cássia Mendes Cândido \\
Araraquara & Anne Karoline Cândido e Silva Bernardes \\
Boa Esperança do Sul & Keila Zólio \\
Borborema & Gláucia Stein Martins \\
Cândido Rodrigues & Andressa Laís de Grande \\
Descalvado & Marília Gabriela Tassim Ghelero \\
Dobrada & Andréa Alves Torres \\
Dourado & Ana Carolina Estevam \\
Gavião Peixoto & Antônio Marcos Gulla \\
Ibaté & Lílian Mayumi Haneda \\
Ibitinga & Lidiane Cássia da Silva \\
Itápolis & Catita Janine Santesso \\
Matão & Josilene Cristina Linhares \\
Motuca & Cláudia Santos Régis \\
Nova Europa & Priscila Tchakerian \\
Porto Ferreira & Lívia \\
Ribeirão Bonito & Daniela Blotta Furlan \\
Rincão & Carlos Alberto Ferreira \\
Santa Ernestina & Aline da Rocha Félix \\
Santa Lúcia & Sandra Regina de Souza de Oliveira \\
São Carlos & Denise Braga e Flávia C. de Souza Zagato \\
Tabatinga & Elaine de Souza Cândido e Camila Oliveira Paiola \\
Taquaritinga & Vanessa Paciello \\
Trabijú & Vanessa Cristina Toni \\
\hline Font Centode Desenva & \\
\hline
\end{tabular}

Fonte: Centro de Desenvolvimento e Qualificação para o SUS - CDQ-SUS, 2017. 


\section{APÊNDICE 2}

Distribuição dos Articuladores de Educação Permanente em Saúde segundo os respectivos municípios que compõem o DRS de Araraquara

\begin{tabular}{l|l}
\hline \multicolumn{1}{c|}{ Município } & \multicolumn{1}{c}{ Nome } \\
\hline Américo Brasiliense & Juliana de Cássia Mendes Cândido \\
Araraquara & Poliana Patrício Aliane \\
Boa Esperança do Sul & Keila Zólio \\
Borborema & Gláucia Stein Martins \\
Cândido Rodrigues & Priscila Malena Bertino Pereira \\
Descalvado & Viviane Cavalcante Pizetta \\
Dobrada & Regiane Macedo Bertonha \\
Dourado & Ana Carolina Estevam \\
Gavião Peixoto & \\
Ibaté & Natália Falvo Simões \\
Ibitinga & Giovana Zilda Vela Teixeira \\
Itápolis & Érika Cristina Diniz \\
Matão & Lucele Schieavetto \\
Motuca & Cláudia Santos Régis \\
Nova Europa & Priscila Tchakerian \\
Porto Ferreira & Lívia \\
Ribeirão Bonito & Daniela Blotta Furlan \\
Rincão & Carlos Alberto Ferreira \\
Santa Ernestina & Aline da Rocha Félix \\
Santa Lúcia & Sandra Regina de Souza de Oliveira \\
São Carlos & Denise Braga e Siliane Martinelli \\
Tabatinga & Elaine de Souza Cândido e Camila Oliveira Paiola \\
Taquaritinga & Vanessa Paciello \\
Trabijú & Vanessa Cristina Toni \\
\hline Fone: Centra & \\
\hline
\end{tabular}

Fonte: Centro de Desenvolvimento e Qualificação para o SUS - CDQ-SUS, 2017. 


\section{APÊNDICE 3}

\section{Termo de Consentimento Livre e Esclarecido}

Prezado(a)Sr(a):

Estamos convidando o(a) sr(a) a participar, voluntariamente, da pesquisa A Análise da Implicação Profissional como um Dispositivo de Educação Permanente em Saúde, sob a responsabilidade do pesquisador Flávio Adriano Borges Melo, aluno do Programa de Pós-Graduação em Enfermagem em Saúde Pública da Escola de Enfermagem de Ribeirão Preto - Universidade de São Paulo.

A pesquisa tem por objetivo geral analisar a implicação profissional com os apoiadores da Política de Humanização (PH) e articuladores de Educação Permanente em Saúde (EPS) dos municípios do Departamento Regional de Saúde (DRS) III de Araraquara/São Paulo. Os objetivos específicos são: Identificar a implicação profissional com os apoiadores da PH e articuladores de EPS desses municípios e Identificar em que a implicação profissional tem facilitado e dificultado no exercício da função apoio pelos apoiadores da PH e articulação pelos articuladores de EPS.

$\mathrm{O}(\mathrm{A}) \operatorname{sr}(\mathrm{a})$ está sendo convidado a participar das seguintes formas de coleta de dados: entrevista semi-estruturadas, grupos de reflexão e restituição.

Caso concorde, será realizada uma entrevista semi-estruturada com o(a) $\operatorname{sr}(a)$, com data, horário e local estabelecidos previamente por meio de contato telefônico, com duração média de duas horas, que deverá ser gravada em mídia digital para posterior transcrição e será composta basicamente de algumas perguntas referentes ao cotidiano do trabalho desenvolvido pelo(a) $\operatorname{sr}($ a) no apoio às equipes de saúde de seu município. Caso necessário, e o(a) sr(a) concordar, poderemos agendar mais de uma entrevista. Além disso, o(a) sr(a) será convidado a participar dos grupos de reflexão com vista a refletir acerca de sua prática profissional, através da utilização de estratégias possíveis de serem replicadas no apoio realizado pelo(a) $\operatorname{sr}(a)$ às equipes de saúde de seu município, configurando o que se chama de pesquisa-intervenção. Estão previstos, pelo menos, cinco encontros entre os apoiadores da PH e articuladores de EPS do DRS de Araraquara e o pesquisador deste projeto. O local e as datas dos encontros serão combinados com o(a) $\operatorname{sr}(a)$ em acordo com o conjunto de apoiadores, articuladores, a DRS e o pesquisador. A duração será de três horas, aproximadamente. Os encontros também serão gravados em mídia digital para transcrição em outro momento e o pesquisador fará anotações em caderno durante a reunião. Além disso, existirá um momento final denominado de Restituição que consiste em um encontro presencial onde todos os apoiadores e articuladores que fizeram parte dessa pesquisa serão convidados(as) a participarem e que serão expostos os resultados das análises realizadas no transcorrer da mesma, podendo o(a) $\operatorname{sr}(a)$ manifestar sua aprovação ou reprovação acerca das análises feitas. Todo o material registrado estará a sua disposição no momento em que desejar e ficará sob a guarda e responsabilidade do pesquisador por um período de cinco anos após o término dessa pesquisa, sendo destruído posteriormente.

As informações/opiniões/imagens emitidas pelo(a) sr(a) serão tratadas de forma anônima no conjunto das demais pessoas que participarem do estudo. Ainda, a qualquer momento da realização da pesquisa, caso não seja de seu interesse a continuidade na participação, haverá possibilidade de retirar este consentimento, e deixar de participar do estudo, sem que isto lhe traga qualquer prejuízo. Ressaltamos que durante a participação, o(a) sr(a) terá como possível risco, o desconforto ao se deparar com situações difíceis do seu trabalho e ter que analisá-las com os demais participantes, podendo por vezes identificar lacunas em seus conhecimentos e habilidades para realizá-lo. Contudo, esclareço que o(a) $\operatorname{sr}(a)$ não é obrigado a responder questões que julgarem desnecessárias ou julgarem que possam ferir sua integridade moral. Outro desconforto ao qual poderá estar exposto(a) será o de expressar sua opinião e também ouvir os presentes no grupo, o que poderá causar tensões, especialmente se houver diferenças de opiniões entre os participantes. Em caso de desconforto, solicitamos, preferencialmente, 
que o manifeste no próprio grupo, pois esse desconforto poderá ser também de outros participantes e, assim, o problema ou dificuldade poderá ter uma solução no próprio grupo, ou seja, o pesquisador utilizará estratégias de mediação para a superação das dificuldades identificadas, amenizando os possíveis desconfortos e também promoverá a atualização de conhecimentos identificados como necessários. $\mathrm{O}(\mathrm{A}) \operatorname{sr}(\mathrm{a})$ poderá também manifestar seu desconforto particularmente ao pesquisador pessoalmente ou através do telefone abaixo indicado, para as devidas providências.

A participação na pesquisa lhe proporcionará benefícios através da vivência grupal com uso de algumas estratégias que facilitam o trabalho em saúde, tais como o diálogo, a comunicação e o enfrentamento de obstáculos no trabalho. $\mathrm{O}(\mathrm{A})$ sr(a) poderá se apropriar de conceitos e estratégias de trabalho com o intuito de aperfeiçoar suas atividades de apoio às equipes de saúde, facilitando também o trabalho em saúde no seu município.

Os resultados da pesquisa serão publicados na forma de uma tese de doutorado e de trabalhos científicos divulgados em eventos científicos como congressos, revistas científicas e para os trabalhadores do DRS de Araraquara.

Se o(a) $\operatorname{sr}(a)$ aceitar o convite para participar da pesquisa, esclarecemos que não está previsto pagamento por esta participação, também não haverá nenhuma despesa financeira ao sr(a).

Caso ocorra algum dano decorrente de sua participação nessa pesquisa, poderá haver indenização conforme as leis vigentes no país.

Caso tenha qualquer dúvida, a qualquer momento, o(a) sr(a) poderá ser esclarecido(a) diretamente com o pesquisador responsável. Caso concorde em participar, uma via original deste termo de consentimento assinada será entregue ao(a) $\operatorname{sr}(a)$. Esclarecemos que esta pesquisa foi aprovada pelo Comitê de Ética em Pesquisa da EERP-USP, Protocolo CAAE no 52679716.8.0000.5393. Caso tenha necessidade, poderá entrar em contato com o Comitê de Ética em Pesquisa da EERP-USP, órgão que tem por objetivo proteger o bem estar dos sujeitos pesquisados, pelo telefone (016)3315-9197, de segunda à sexta-feira, das 8:00 às 17:00 horas.

Agradecemos sua colaboração e ressaltamos a importância de sua participação nesta pesquisa para produção de conhecimentos em saúde.

Flávio Adriano Borges Melo

flavioborges@usp.br

$\mathrm{Eu}$ aceito participar da pesquisa $A$

Análise da Implicação Profissional como um Dispositivo de Educação Permanente em Saúde.

de de 
ANEXO 


\section{ESCOLA DE ENFERMAGEM DE Plotoformo RIBEIRÃO PRETO - USP}

\section{PARECER CONSUBSTANCIADO DO CEP}

\section{DADOS DO PROJETO DE PESQUISA}

Título da Pesquisa: A Análise da Implicação Profissional como um Dispositivo de Educação Permanente em Saúde

Pesquisador: Flávio Adriano Borges Melo

Área Temática:

Versão: 2

CAAE: 52679716.8 .0000 .5393

Instituição Proponente: Escola de Enfermagem de Ribeirão Preto - USP

Patrocinador Principal: Financiamento Próprio

\section{DADOS DO PARECER}

Número do Parecer: 1.568 .447

Apresentação do Projeto:

Trata-se da avaliação das respostas à pendências

Objetivo da Pesquisa:

Sem alteração

Avaliação dos Riscos e Benefícios:

Sem alteração

Comentários e Considerações sobre a Pesquisa:

Sem alteração

Considerações sobre os Termos de apresentação obrigatória:

A divergência entre o número de participantes informado na folha de rosto e no projeto foi esclarecida;

O número telefônico do CEP foi corrigido.

Conclusões ou Pendências e Lista de Inadequações:

Projeto aprovado

Considerações Finais a critério do CEP:

Parecer aprovado Ad Referendum

Endereço: BANDEIRANTES 3900

Bairro: VILA MONTE ALEGRE CEP: $14.040-902$

UF: SP Município: RIBEIRAO PRETO

Telefone: (16)3315-9197

E-mail: cep@eerp.usp.br 


\section{ESCOLA DE ENFERMAGEM DE RIBEIRÃO PRETO - USP}

Continuação do Parecer: 1.568.447

Este parecer foi elaborado baseado nos documentos abaixo relacionados:

\begin{tabular}{|c|c|c|c|c|}
\hline Tipo Documento & Arquivo & Postagem & Autor & Situação \\
\hline $\begin{array}{l}\text { Informações Básicas } \\
\text { do Projeto }\end{array}$ & $\begin{array}{l}\text { PB_INFORMAÇÖES_BÁSICAS_DO_P } \\
\text { ROJETO 619738.pdf }\end{array}$ & $\begin{array}{c}11 / 05 / 2016 \\
09: 33: 21 \\
\end{array}$ & & Aceito \\
\hline $\begin{array}{l}\text { Projeto Detalhado / } \\
\text { Brochura } \\
\text { Investigador }\end{array}$ & $\begin{array}{l}\text { Projeto_Doutorado_Flavio_Adriano_Bor } \\
\text { ges_Melo.pdf }\end{array}$ & $\begin{array}{l}11 / 05 / 2016 \\
09: 32: 45\end{array}$ & $\begin{array}{l}\text { Flávio Adriano } \\
\text { Borges Melo }\end{array}$ & Aceito \\
\hline Outros & Oficio_Pendencia.pdf & $\begin{array}{c}11 / 05 / 2016 \\
09: 32: 10\end{array}$ & \begin{tabular}{|l|} 
Flávio Adriano \\
Borges Melo
\end{tabular} & Aceito \\
\hline $\begin{array}{l}\text { TCLE / Termos de } \\
\text { Assentimento / } \\
\text { Justificativa de } \\
\text { Ausência }\end{array}$ & TCLE.pdf & $\begin{array}{c}11 / 05 / 2016 \\
09: 10: 40\end{array}$ & $\begin{array}{l}\text { Flávio Adriano } \\
\text { Borges Melo }\end{array}$ & Aceito \\
\hline Outros & Oficio.pdf & $\begin{array}{c}22 / 01 / 2016 \\
19: 54: 02 \\
\end{array}$ & \begin{tabular}{|l|} 
Flávio Adriano \\
Borges Melo \\
\end{tabular} & Aceito \\
\hline Outros & Termos_Assinados_Agrupados.pdf & $\begin{array}{c}22 / 01 / 2016 \\
19: 53: 13 \\
\end{array}$ & $\begin{array}{l}\text { Flávio Adriano } \\
\text { Borges Melo }\end{array}$ & Aceito \\
\hline Cronograma & Cronograma.pdf & $\begin{array}{c}22 / 01 / 2016 \\
19: 51: 48\end{array}$ & $\begin{array}{l}\text { Flávio Adriano } \\
\text { Borges Melo }\end{array}$ & Aceito \\
\hline Orçamento & Orcamento_Financeiro.pdf & $\begin{array}{l}11 / 01 / 2016 \\
13: 33: 06\end{array}$ & $\begin{array}{l}\text { Flávio Adriano } \\
\text { Borges Melo }\end{array}$ & Aceito \\
\hline Folha de Rosto & Folha_de_Rosto.pdf & $\begin{array}{c}07 / 01 / 2016 \\
16: 59: 44\end{array}$ & \begin{tabular}{|l|} 
Flávio Adriano \\
Borges Melo
\end{tabular} & Aceito \\
\hline
\end{tabular}

Situação do Parecer:

Aprovado

Necessita Apreciação da CONEP:

Não

RIBEIRAO PRETO, 31 de Maio de 2016

Assinado por:

Angelita Maria Stabile

(Coordenador)

Endereço: BANDEIRANTES 3900

Bairro: VILA MONTE ALEGRE CEP: $14.040-902$

UF: SP Município: RIBEIRAO PRETO

Telefone: (16)3315-9197

E-mail: cep@eerp.usp.br 